UNIVERSIDADE DE BRASILIA - UNB

INSTITUTO DE CIÊNCIAS BIOLÓGICAS - UNB

PROGRAMA DE PÓS-GRADUAÇÃO EM BIOLOGIA MOLECULAR

LABORATÓRIO DE ANÁLISES MOLECULARES DE PATÓGENOS - LAMP

DISSERTAÇÃO DE MESTRADO

AVALIAÇÃO DA ATIVIDADE COMO CHAPERONA E DO POTENCIAL IMUNODIAGNÓSTICO DA PROTEÍNA TCTP DE PARACOCCIDIOIDES SPP.

Luis Janssen Maia

Orientador: Dr. Vicente de Paulo Martins

Co-orientador: Dra. Maria Sueli Soares Felipe

Brasília - DF 
AVALIAÇÃO DA ATIVIDADE COMO CHAPERONA E DO POTENCIAL IMUNODIAGNÓSTICO DA PROTEÍNA TCTP DE PARACOCCIDIOIDES SPP.

Dissertação apresentada como requisito parcial para a obtenção do título de Mestre pelo programa de Pós-graduação em Biologia Molecular do Instituto de Ciências Biológicas, Universidade de Brasília.

Orientador: Dr. Vicente de Paulo Martins Co-orientador: Dra. Maria Sueli Soares Felipe 


\section{AVALIAÇÃO DA ATIVIDADE COMO CHAPERONA E DO POTENCIAL IMUNODIAGNÓSTICO DA PROTEÍNA TCTP DE PARACOCCIDIOIDESSPP.}

Dissertação apresentada como requisito parcial para a obtenção do título de Mestre pelo programa de Pós-graduação em Biologia Molecular do Instituto de Ciências Biológicas, Universidade de Brasília.

Luis Janssen Maia

Dissertação aprovada em:

Comissão julgadora:

$1^{\circ}$ Mem. (Presidente):

Prof. Dr. Vicente de Paulo Martins (UnB)

$2^{\circ}$ Membro:

Prof. ${ }^{a}$ Dra. Larissa Fernandes Matos (UnB)

$3^{\circ}$ Membro:

Prof. Dr. João Alexandre Ribeiro Gonçalves Barbosa (UnB)

$4^{\circ}$ Membro (Suplente):

Prof ${ }^{a}$ Dra. Tatiana Amabile de Campos (UnB) 
O presente trabalho foi realizado no Laboratório de Análises Moleculares de Patógenos, do Instituto de Ciências Biológicas da Universidade de Brasília.

Financiamento: FAPDF/ FAHUB/ CNPq 


\section{Dedicatória}

"Em todas as coisas, um coração calmo deve prevalescer"

"Fawkes", "Fallout 3", Bethesda Game Studios

A minha mãe Maria Esther,

A meu tio Chico (In memoriam),

A minha tia Mariana. 


\section{Agradecimentos}

Agradeço aos meus orientadores Vicente de Paulo Martins e Maria Sueli Soares Felipe pela disposição em ensinar, ajudar e acreditar, além de ambos possuírem uma paciência impressionante comigo.

Agradeço às agências FAPDF, CNPq e FAHUB pelo auxílio financeiro, bem como o programa de pós-graduação em biologia molecular por oferecer disciplinas importantes para a minha formação, além do suporte para a execução do projeto.

Agradeço aos professores Robert Miller, Sonia Freitas, Isabela Charneau, Beatriz de Lima, Tatiana Amabile e Carlos André Ricart que me ajudaram, seja na sugestão ou na execução de ideias do projeto, seja em aspectos relativos aos trâmites do programa de pósgraduação.

Agradeço aos vários colegas e amigos que conheci ao longo do mestrado, pela convivência amistosa e pelas oportunidades que surgiram a partir dessa convivência para me tornar um estudante melhor e, talvez, uma pessoa melhor. Agradeço a Anderson, Hérick, Gisele, Laura, Rafa, Letícia, Juliana Goes, Juliana Simas, Lucas Melo, Márcio e tantos outros, assim como aqueles que, embora não façam parte do laboratório, foram importantes: Agnelo, Amanda, Clênia, Camila e Nicholas. Peço desculpas a quem não teve o nome lembrado nesse breve parágrafo, o mais importante foi a convivência, não essas poucas palavras incapazes de fazer justiça ao apoio que recebi.

Agradeço aos meus amigos de outros momentos e minha família, cujo apoio foi fundamental para o meu sustento pessoal e cujo incentivo é mister para que eu continue seguindo na pesquisa.

Obrigado por tudo. 


\section{Resumo}

A paracoccidioidomicose é uma micose sistêmica causada por fungos termodimórficos do gênero Paracoccidioides. Embora seja uma das micoses sistêmicas de maior importância na América Latina, tanto por número de ocorrências quanto pela morbidade causada pela forma crônica da doença, trata-se de uma doença negligenciada e, portanto, váriosaspectos relevantes à clínica da micose e à biologia do fungo não estão bem elucidados. A despeito dos registros de ocorrência da micose, o diagnóstico dessa é de difícil execução, pela dificuldade de se isolar o fungo a partir de hospedeiros infectados e pela relativa falta de padronização e elevada ocorrência de reações cruzadas em testes de imunodiagnóstico. Assim, dentre as estratégias para a melhoria do diagnóstico da doença, está o uso de proteínas expressas de forma heteróloga para servirem como alvos mais específicos e padronizáveis nestes testes. Já em relação à biologia de fungos, é sabido que poucas espécies fúngicas são capazes de infectar organismos homeotérmicos, em relação ao número de espécies capazes de infectar organismos pecilotérmicos. Em face disso, alguns trabalhos na literatura sugerem que a temperatura dos hospedeiros representa uma barreira importante para a infecção fúngica e que os mecanismos moleculares de termotolerância dos fungos patogênicos são fatores de virulência importantes. Recentemente, a proteína TCTP foi encontrada em trabalhos de proteoma em ambas as fases micelial e leveduriforme de Paracoccidioides lutzii, além de possuir estrutura primária idêntica à TCTP de Paracoccidioides brasiliensis, fazendo dessa proteína um candidato para imunodiagnóstico. Além disso, a proteína TCTP foi apontada em outros organismos como uma chaperona molecular de importância em situações de estresse térmico. Assim, o presente trabalho objetiva avaliar estas duas vertentes para os fungos do gênero Paracoccidioides. Propiedades relevantes para o imunodiagnóstico foram preditas in silico e apontam para a presença de fosforilações na proteína, bem como um alto grau de conservação de estrutura primária em eucariotos e, particularmente, em fungos. A proteína foi produzida em quantidades apreciáveis e com pureza considerável por meio de expressão heteróloga em Escherichia coli. Ensaios de ELISA e Western Blot utilizando a TCTP indicam que a proteína não foi reconhecida pela maioria dos soros oriundos de camundongos infectados com P.brasiliensis. Já em relação às propriedades de chaperona, ensaios de dicroísmo circular indicam que a proteína nativa é termoestável. Além disso, a expressão da TCTP em culturas de E.coli as tornaram mais resistentes a estresse térmico. Como perspectivas a esse trabalho estão a aplicação de sub-regiões da proteína como alvos em imunodiagnóstico e aplicações no desenvolvimento de vacinas contra a micose, além de se caracterizar as propriedades de chaperona propriamente ditas da TCTP. 
Palavras chave: Paracoccidioides, paracoccidioidomicose, expressão heteróloga, imunodiagnóstico, chaperona, dicroísmo circular, termotolerância, TCTP. 


\section{Abstract}

Paracoccidioidomycosis is a systemic mycosis caused by thermodimorphic fungi of the Paracoccidioides genus. Even though it is one of the most important systemic mycosis in Latin America, as a consequence of the number of its occurrences and the morbidity caused by the chronic phase of the disease, it is a neglected disease and, as such, many relevant aspects of its clinical approach and of the fungal biology are yet to be characterized. Despite the high occurrence records, the diagnostic of this mycosis is hard to be executed, because of the difficulty of isolating the fungus from infected hosts and because of the high cross-reaction occurrences in immunodiagnostic tests. In order to improve the diagnostics, one of the strategies being employed is the use of heterologously expressed proteins as targets of the immunodiagnostic tests, as they can be more precise and standardisable targets. As for the fungal biology, it is known that few fungal species are able to infect homeotherm hosts, in comparison to the number of species able to infect poikilotherm hosts. In face of this, some studies in the literature suggest the host temperature as an important barrier to the fungal infection and molecular mechanisms associated with the fungal thermotolerance as important virulence factors. Recently, the TCTP protein was found in proteome studies of both the mycelial and yeast forms of Paracoccidioides lutzii, in addition of having identical primary protein structure with the Paracoccidioides brasiliensis form of TCTP, properties which make this protein an interesting target for immunodiagnostics. In addition, the TCTP protein was identified as a molecular chaperone with significant importance in thermal stress situations. Therefore, the present study aims to evaluate these two aspects for the fungi of the Paracoccidioides genus. Relevant properties for the immunodiagnosis using this protein were predicted in silico and point to a considerable amount of phosphorilations in it as well as a high conservation of it among eukariotes and, particularly, in fungi. The protein was produced in considerable amounts and purity through heterologous expression in Escherichia coli.Immunodiagnostic tests of ELISA and Western Blot assays using the TCTP indicate this protein as not being recognized by most mice sera experimentally infected with P.brasiliensis. As in relation to the chaperone properties of the protein, circular dichroism assays indicate the native protein as thermally stable. Moreover, TCTP expression in E.coli cultures made them more resistant to thermal stress. The perspectives of this study are the application of subregions of the protein as targets in immunodiagnostic assays, as well as applications in vaccine development against the mycosis and the evaluation of the chaperone properties themselves of TCTP.

Keywords: Paracoccidioides, paracoccidioidomycosis, heterologous expression, immunodiagnostics, chaperone, circular dichroism, thermotolerance, TCTP. 


\section{Lista de Figuras}

Figura 1. Processo infectivo do Paracoccidioides................................... 17

Figura 2. Frações de crescimento de espécies fúngicas por temperatura ......... 20

Figura 3. A proteostase como resultado da interação entre biogênese, $\quad 22$ degradação e manutenção conformacional das proteínas, com as proteínas chaperonas intermediando esses sistemas.

Figura 4. Funil de energia livre esquematizando caminhos irregulares, energicamente favoráveis, entre proteínas recém-sintetizadas e nativas ou agregadas, mostrando o papel de chaperonas no processo.

Figura 5. Alinhamento entre estruturas primárias de diferentes espécies de TCTP

Figura 6. Estrutura terciária da TCTP.

Figura 7. Esquema resumindo parcialmente a regulação e funções da proteína TCTP....

Figura 8. Esquema representativo do delineamento experimental do trabalho.

Figura 9. Mapa do plasmídeo pLEXSY-2 com destaque para a região polylinker....

Figura 10. Mapa do plasmídeo pET28a com destaque para a região polylinker.

Figura 11. Predição de peptídeo sinal pelo programa SignalP e de domínio transmembrana pelo programa TMHMM.

Figura 12.

Predição de fosforilações sobre a proteína TCTP pelo programa Netphos.

Figura 13. Predição de N-glicosilações pelo programa NetNglyc1.0 sapiens e Mus musculus.

Figura 16. Alinhamento múltiplo entre TCTP de Paracoccidioides e proteínas de outras espécies fúngicas.

Figura 17. Resultado da PCR em gel de agarose a $1 \%$. sequenciamento do inserto TCTP e a sequência de Paracoccidioides brasiliensis depositada no banco nucleotide do NCBI.

Figura 19. Alinhamento múltiplo entre a proteína codificada pelo inserto TCTP e as proteínas TCTP de Paracoccidioides spp.

Figura 20. Gel SDS-PAGE 0,75 $\mathrm{mm}$ a $12 \%$ de acrilamida com amostras de colônias de E. coli Rosetta pET28/TCTP induzidas a expressar TCTP em diferentes intervalos de tempo.

Figura 21. Gel SDS-PAGE 0,75mm a 12\% de acrilamida porção solúvel e insolúvel de pellet de colônias de E.coli Rosetta pET28/TCTP induzidas a expressar TCTP, após sonicação

Figura 22. Gel SDS-PAGE 15\% de proteínas TCTP, em meio aquoso, após purificação em coluna de níquel 
Figura 23. Western Blot da proteína purificada com anticorpo primário Anti-His. 56

Figura 24. Western blot de detecção de proteínas heterólogas de E.coli contra 57 soros de camundongos infectados por Pb18

Figura 25. Absorbância sinal gerada a partir do teste ELISA

Figura $26 \quad$ Eletroforese em gel de agarose a 1\% da PCR do gene TCTP a partir de DNA isolado de L.tarentolae.

Figura 27. Espectro da estrutura secundaria da chaperona na região distante da UV (260-190 nm) em tampão Tris $\mathrm{HCl}$ pH 7,0 (2 mM) na temperatura de $25^{\circ} \mathrm{C}$

Figura 28. Curva de desnaturação térmica, em tampão Tris $\mathrm{HCl}$ pH 7,0 (2 mM), da chaperona monitorada em $208 \mathrm{~nm}$ apresentando estabilidade com aumento da temperatura

Figura 29. Espectros da curva de desnaturação térmica da chaperona (25 - 95 $\left.{ }^{\circ} \mathrm{C}\right)$ em região distante do UV (260-190 nm), em tampão Tris $\mathrm{HCl} \mathrm{pH}$ $7,0(2 \mathrm{mM})$.

Figura 30. Teste de chaperona utilizando EcoRI e pGEM-tEASY incubados após 20 minutos a $65^{\circ} \mathrm{C}$ e depois a 2 horas a $37^{\circ} \mathrm{C}$.

Figura 31. Curva de cinética de absorbância a 360nm de diferentes concentrações de BSA em tampão PBS pH 7,4 e 20mM de DTT.

Figura 32. Curva de cinética de absorbância a 360nm de BSA em $5 \mathrm{mg} / \mathrm{mL}$ e diferentes quantidades de TCTP em tampão PBS pH 7,4 e 20mM de

Figura 33. Ensaio de termotolerância em E.coli. 


\section{Lista de Tabelas}

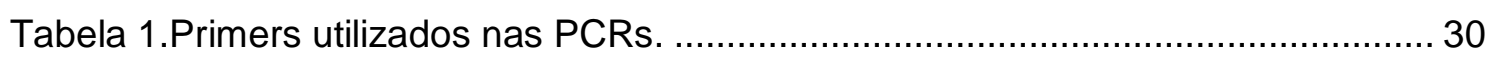




\section{Lista de Abreviaturas}

\begin{tabular}{|c|c|}
\hline${ }^{\circ} \mathrm{C}$ & Graus Célsius \\
\hline$\mu \mathrm{g}$ & Micrograma \\
\hline$\mu \mathrm{L}$ & Microlitro \\
\hline$\theta$ & Elipticidade \\
\hline [ $\theta$ ] & Elipticidade molar \\
\hline AIDS & Acquired Immunodeficiency Syndrome \\
\hline Anti-his & Anti-histidina \\
\hline B3 & Buffer 3 \\
\hline B5 & Buffer 5 \\
\hline $\mathrm{BHI}$ & Brain-Heart Inusion \\
\hline bis-ANS & 4,4'-bis(1-anilinonaphthalene 8-sulfonate) \\
\hline BSA & Bovine serum albumine \\
\hline $\mathrm{BCIP}$ & 5-bromo-4-chloro-3-indolyl-phosphate \\
\hline $\mathrm{CaCl}_{2}$ & Cloreto de cálcio \\
\hline $\mathrm{cm}$ & Centímetro \\
\hline DC & Dicroísmo circular \\
\hline DF & Distrito Federal \\
\hline DMSO & Dimethyl sulfoxide \\
\hline DNA & Deoxyribonucleic acid \\
\hline DTT & Ditiotreitol \\
\hline EDTA & EtilenoDiaminoTetraAcético \\
\hline ELISA & Enzyme-Linked Immunosorbent Assay \\
\hline g & Grama, forçaxg \\
\hline gp43 & Glicoprotein43 \\
\hline $\mathrm{h}$ & Hora \\
\hline $\mathrm{H}_{2} \mathrm{O}_{2}$ & Peróxido de hidrogênio \\
\hline $\mathrm{HCl}$ & Ácido clorídrico \\
\hline HEPES & (4-(2-hydroxyethyl)-1-piperazineethanesulfonic acid) \\
\hline HSR & Heat shock response \\
\hline HRF & Histamine release factor \\
\hline IDT & Integrated DNA technologies \\
\hline $\lg G$ & Imunoglobulina $\mathrm{G}$ \\
\hline IPTG & Isopropyl $\beta-D-1$-thiogalactopyranoside \\
\hline (s) $\mathrm{HSP}(\mathrm{s})$ & (Small) Heat shock protein(s) \\
\hline $\mathrm{kb}$ & Kilobase \\
\hline $\mathrm{KCl}$ & Cloreto de potássio \\
\hline $\mathrm{kDa}$ & Kilodalton \\
\hline LB & Lisogeny Broth \\
\hline $\mathrm{MnCl}_{2}$ & Cloreto de Manganês \\
\hline M & Molar \\
\hline $\mathrm{mA}$ & Miliampere \\
\hline mdeg & Milidegree \\
\hline $\mathrm{mM}$ & Milimolar \\
\hline $\mathrm{mm}$ & Milímetro \\
\hline Mmi1 & Microtubule and mitochondria interacting \\
\hline $\mathrm{mL}$ & Mililitro \\
\hline $\mathrm{Na}_{2} \mathrm{HPO}_{4}$ & Fosfato de sódio dibásico \\
\hline $\mathrm{NaCl}$ & Cloreto de sódio \\
\hline $\mathrm{NaH}_{2} \mathrm{PO}_{4}$ & Fosfato de sódio monobásico \\
\hline $\mathrm{Na}_{2} \mathrm{CO}_{3}$ & Carbonato de sódio \\
\hline $\mathrm{NaHCO}_{3}$ & Bicarbonato de sódio \\
\hline nBLAST & Nucleotide Basic Local Alignment Search Tool \\
\hline
\end{tabular}




\begin{tabular}{|c|c|}
\hline NBT & Nitro blue tetrazolium \\
\hline $\mathrm{NCBI}$ & National Center for Biotechnological Information \\
\hline ng & Nanograma \\
\hline $\mathrm{nm}$ & Nanômetro \\
\hline OPD & O-Phenylenediamine dihydrochloride \\
\hline $\mathrm{p} / \mathrm{v}$ & Peso/volume \\
\hline p21 & Protein 21 \\
\hline p23 & Protein 23 \\
\hline PAGE & PolyAcrylamide Gel Electrophoresis \\
\hline $\mathrm{pb}$ & Pares de base \\
\hline pb27 & P. brasiliensis protein 27 \\
\hline pb40 & Paracoccidioides brasiliensis protein 40 \\
\hline pBLAST & Protein Basic Local Alignment Search Tool \\
\hline PBS & Phosphate buffer saline \\
\hline PBST & Phosphate buffer saline with tween \\
\hline PCM & Paracoccidioidomicose \\
\hline PCR & Polymerase chain reaction \\
\hline PDB & Protein Data Bank \\
\hline $\mathrm{pH}$ & Potencial hidrogeniônico \\
\hline rpm & Rotações por minuto \\
\hline SDS & Sodium dodecyl sulfate \\
\hline SFB & Soro fetal bovino \\
\hline plp43 & Paracoccidioides lutzii protein43 \\
\hline Q23 & Quiescent protein 23 \\
\hline TAE & Tris-acetato-EDTA \\
\hline Taq & Thermus aquaticus \\
\hline TB & Tris-borato \\
\hline TCTP & Translationally controlled tumor protein \\
\hline TPT-1 & Tumor protein 1 \\
\hline UFCs & Unidades formadoras de colônia \\
\hline UPR & Unfolded protein response \\
\hline UPS & Ubiquitin-proteasome response \\
\hline V & Volts \\
\hline $\mathrm{v} / \mathrm{v}$ & volume/volume \\
\hline X-gal & 5-bromo-4-chloro-3-indolyl- $\beta$-D-galactopyranoside, BCIG \\
\hline
\end{tabular}




\section{Sumário}

1.Introdução

1.1Paracoccidioidomicose.

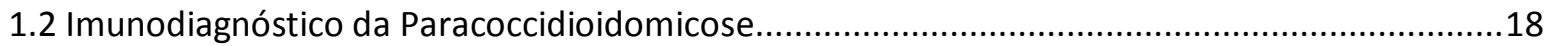

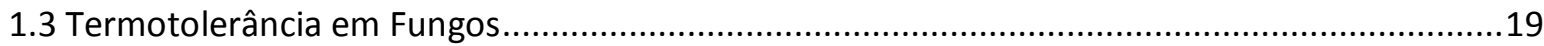

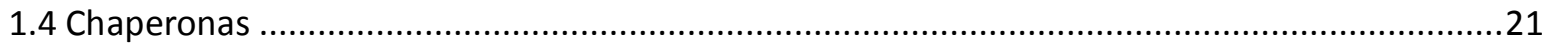

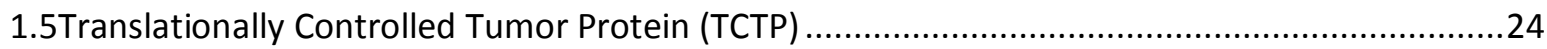

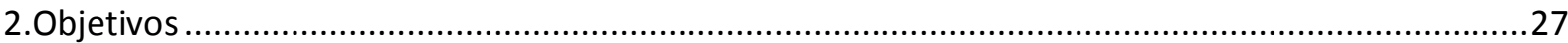

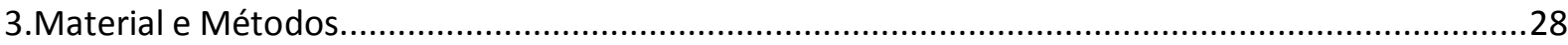

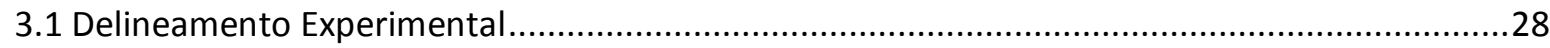

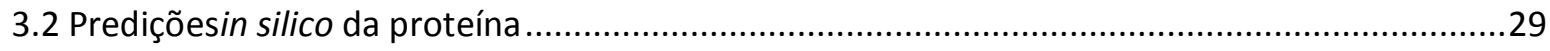

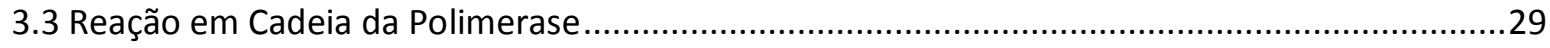

3.4 Análises de DNA em eletroforese em gel de agarose ..............................................................

3.5 Clonagem de amplicons em plasmídeo pGEM-tEASY ...............................................................

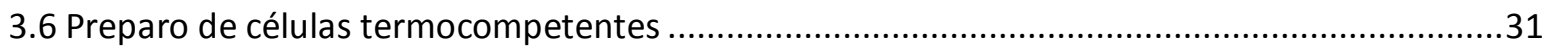

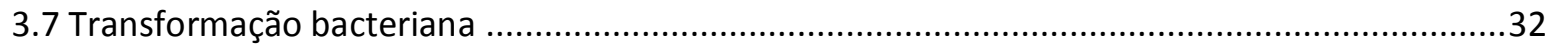

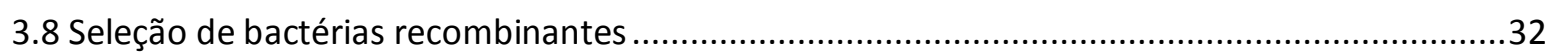

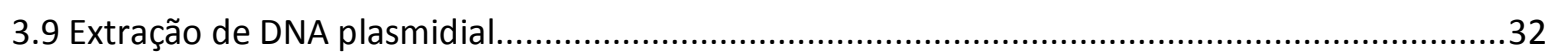

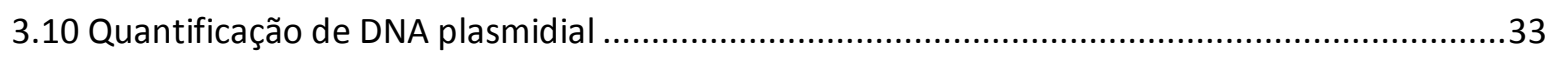

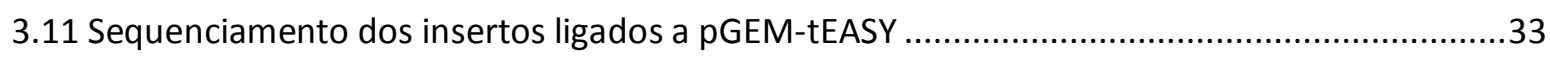

3.12 Digestão por enzimas de restrição de pGEM-tEASY e pLEXSY-2 …..........................................33

3.13 Sub-clonagem de inserto em plasmídeos pLEXSY-2 e pET28a ...............................................34

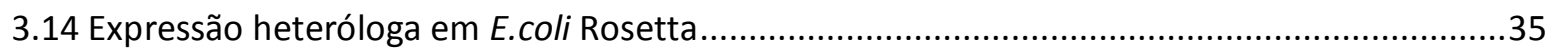

3.15 Sonicação de culturas para a extração proteica …..............................................................36

3.16 Cultivo e eletroporação em Leishmania tarentolae ................................................................36

3.17 Extração de DNA total de L. tarentolaee confirmação da presença de inserto ..........................37

3.18 Purificação da proteína heteróloga por cromatografia de afinidade por íons metálicos

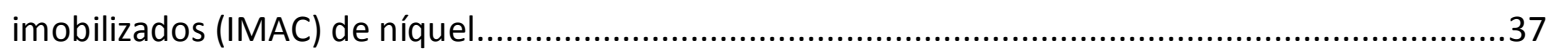

3.19 Análises de proteínas em eletroforese desnaturante de poliacrilamida (SDS-PAGE) ...............38

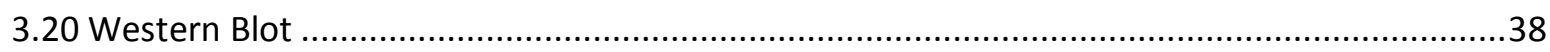

3.21 Ensaio de Imunoabsorbância Enzimática (Enzyme Linked Immunosorbent Assay - ELISA) ........39

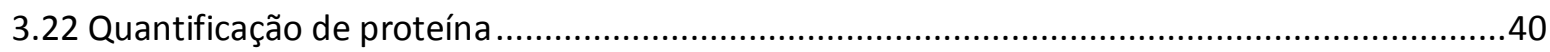

3.23 Análises de estruturas secundárias e estabilidade estrutural por Dicroísmo Circular ..............40

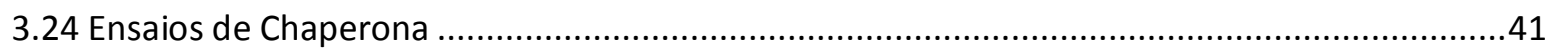

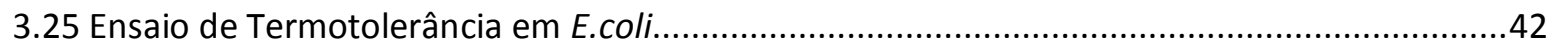


3.26 Análises estatísticas.

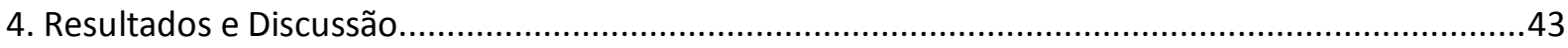

4.1 Predições in silico da proteína ................................................................................43

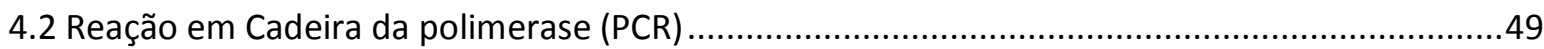

4.3 Sequenciamento dos insertos ligados a pGEM-tEASY ................................................50

4.4 Sub-clonagem de inserto em plasmídeos pLEXSY-2 e pET28a..........................................52

4.5 Expressão heteróloga em E.coli Rosetta..................................................................52

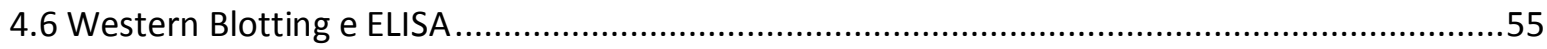

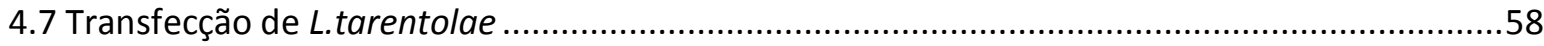

4.8Análises de estruturas secundárias e estabilidade estrutural por Dicroísmo Circular ................59

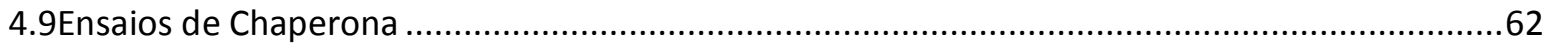

4.10Ensaio de Termotolerância em E.coli ........................................................................64

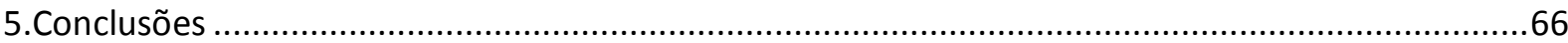

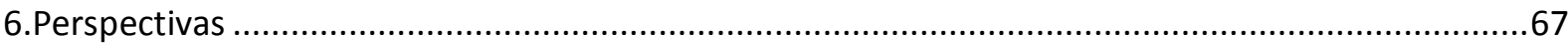

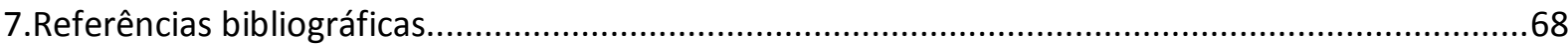




\section{Introdução}

\subsection{Paracoccidioidomicose}

A Paracoccidioidomicose (PCM) é uma micose sistêmica causada por fungos termodimórficos do gênero Paracoccidioides: Paracoccidioides brasiliensis e Paracoccidioides lutzii(TEIXEIRA et al., 2009). Esse gênero pertence à ordem Onygenales e à família Ajellomycetaceae, a qual inclui outros gêneros de fungos dimórficos patogênicos ao homem, como Blastomyces e Histoplasma (UNTEREINER et al., 2004).

A PCM é considerada uma das principais micoses sistêmicas da América Latina, ocorrendo principalmente no Brasil, Colômbia, Venezuela e Argentina, mas a notificação de seus casos para as autoridades de saúde dos países não é compulsória, tornando escassos os dados de sua epidemiologia (NUCClet al., 2009). Entre 1998 e 2006 no Brasil, foram contabilizadas 6732 hospitalizações por PCM, distribuídas em 27\% dos municípios do Brasil(COUTINHOet al., 2015). Estima-se que, para o período de 1996 a 2006, a PCM foi a principal causa de morte dentre as micoses sistêmicas no Brasil, representando cerca de $50 \%$ do total de mortes causadas por micoses sistêmicas(PRADO et al., 2009).

A PCM é adquirida por meio da inalação de propágulos infectivos, como hifas ou esporos, vindos do solo. Uma vez instalados nos pulmões, os propágulos se desenvolvem em formas leveduriformes, as quais são infectivas (Figura 1). A transição do micélio fúngico, forma presente no ambiente, às leveduras é acionada pela mudança de temperatura entre o ambiente e o hospedeiro, processo esse chamado de termodimorfismo (GONZALEZ; HERNANDEZ, 2016; NUCClet al., 2009). Além do ser humano, o Paracoccidioides é capaz de infectar outros mamíferos e aves, como tatus, porcos, coelhos e galinhas (GONZALEZ; HERNANDEZ, 2016). 


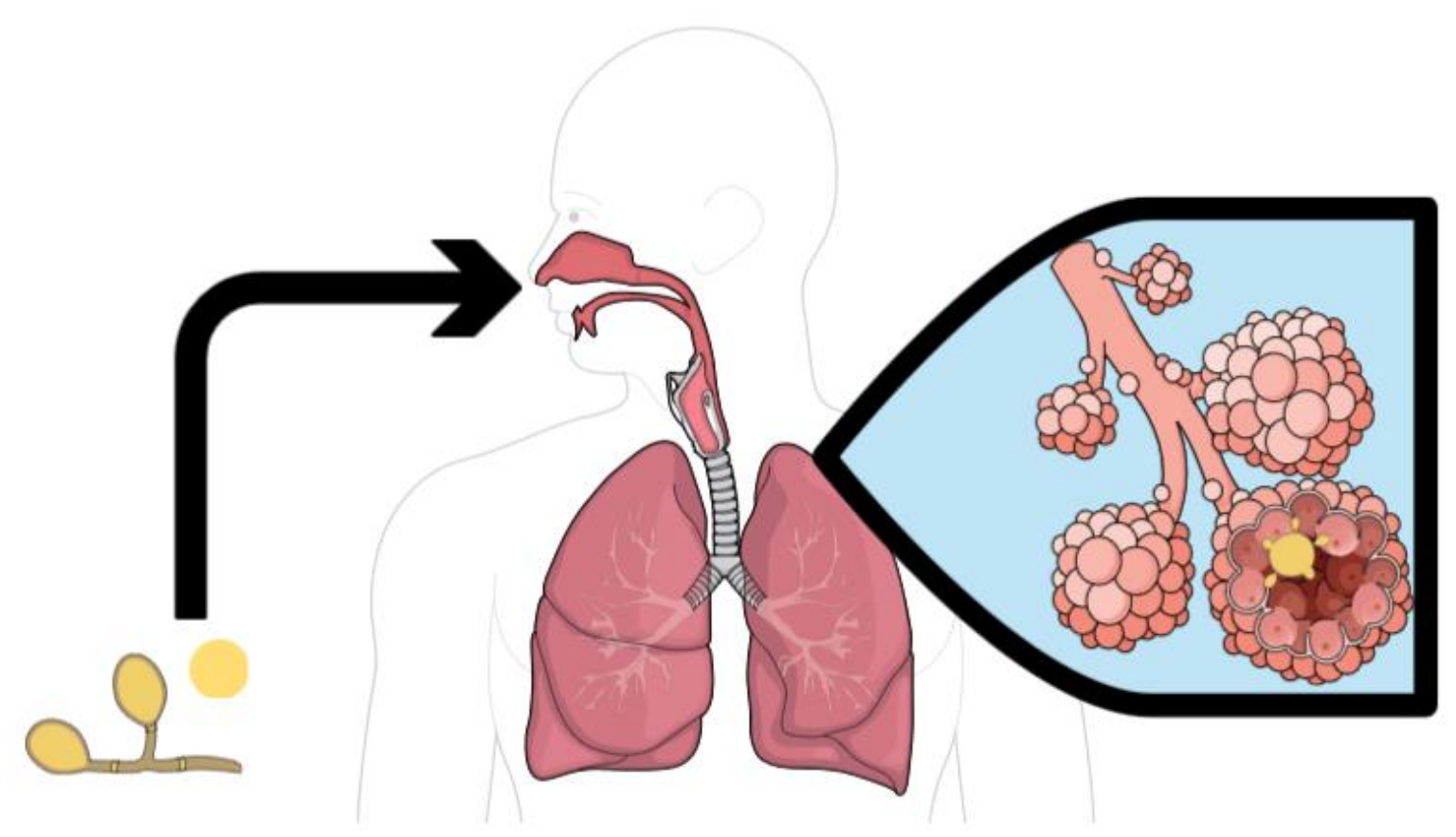

\section{MINDTHE GRAPH.com}

Figura 1. Processo infectivo do Paracoccidioides. Propágulos, como hifas ou esporos são inalados pelo hospedeiro, onde se desenvolvem em leveduras. Os organismos ilustrados na figura estão exibidos fora de sua proporção natural. Imagem feita por meio do site "mindthegraph.com"

As manifestações clínicas da PCM podem ser classificadas em assintomáticas, sintomáticas agudas e sintomáticas crônicas. A forma assintomática é caracterizada pela ausência de sinais e sintomas clínicos, mas pela presença de fungos no hospedeiro, os quais podem permanecer nesse estado de quiescência por anos. A forma aguda, ou juvenil, corresponde a cerca de $10 \%$ dos casos de PCM e é caracterizada por febre, perda de peso e inchaço dos linfonodos, além da presença dos fungos. Já a fase crônica, ou adulta, corresponde a cerca de $90 \%$ dos casos de PCM e é caracterizada por lesões ulcerativas e granulomatosas, geralmente nos pulmões, mas também podendo ocorrer no resto do trato respiratório, pele e, em ocorrências mais raras, no sistema nervoso central, ossos, articulações, órgãos genitais, olhos, tireóide e sistema cardiovascular (GONZALEZ; HERNANDEZ, 2016; NUCClet al., 2009).

Desde a primeira descrição da PCM em 1908 por Adolpho Lutz (MARQUES, 2008), vários avanços foram feitos no entendimento da patogênese, tratamento e diagnóstico da doença, no entanto ainda resta muito a se elucidar, particularmente quanto ao diagnóstico da 
PCM(DA SILVA et al., 2016), além de aspectos da biologia molecular e patogênese por parte do agente etiológico.

\subsection{Imunodiagnóstico da Paracoccidioidomicose}

O padrão ouro para o diagnóstico da PCM é a visualização das leveduras de Paracoccidioides, a partir de uma amostra clínica ou de cultura feita a partir de uma amostra clínica. No entanto, a sensibilidade desse tipo de teste é baixa, se a amostra clínica possui uma diversidade de microorganismos alta, como em expectorações. Além disso, o crescimento de fungos como o Paracoccidioides em cultura é muito lento, podendo durar semanas. Assim, a forma mais comum de diagnóstico da PCM é por métodos sorológicos (VIDAL et al., 2014).

Os métodos sorológicos de diagnóstico costumam se basear em exoantígenos ou antígenos livres de células, feitos a partir da cultura de leveduras. Por não existir uma forma padronizada de se preparar os antígenos, podem existir várias diferenças entre a reatividade deles, o que ajuda a explicar as diferenças entre os resultados desses testes em diferentes centros de diagnóstico. Os fatores que podem contribuir para essa variabilidade incluem a temperatura de cultura das leveduras, a cepa do inóculo, o tamanho do inóculo, a presença de agitação na cultura, entre outros (VIDAL et al., 2014). Outro problema em relação à padronização desses antígenos é que, por haver uma mistura complexa de antígenos, alguns dos quais presentes em outras espécies fúngicas, a quantidade de falsos-positivos vindos desses testes é alta. Assim, o diagnóstico deve ser feito usando-se mais de um preparado de antígenos (FERNANDES et al., 2011). Um dos principais fatores responsáveis pela quantidade de falsos positivos nesses testes é a presença de galactose ligada às proteínas (ALBUQUERQUEet al., 2005; NEVES et al., 2003).

O principal antígeno isolado usado nos métodos sorológicos da PCM é a glicoproteína gp43, a qual foi identificada como o antígeno predominante em immunoblotde exoantígenos, possuindo alta sensibilidade e especificidade contra P.brasiliensis(CAMARGOet al., 1989; CISALPINO et al., 1996). Apesar disso, em ensaios de Western Blot com exoantígenos de P.lutzii e soro de pacientes infectados por P.brasiliensis não há o reconhecimento dos antígenos. Já quando são usados os exoantígenos de $P$. brasiliensis contra o soro de pacientes infectados por P.lutzii há o reconhecimento de várias bandas, apontando que a diversidade de antígenos em P.lutzii é maior do que em P.brasiliensis (GEGEMBAUER et al., 2014). Em ensaios de immunoblot utilizando-se o soro de pacientes infectados por P.brasiliensis contra a proteína ortóloga de gp43 de P.lutzii, Plp43, não há o reconhecimento de antígeno, o que aconteceria porque a identidade de resíduos de aminoácido entre essas proteínas é de $81 \%$, mudando principalmente a região do peptídeo p10, a qual é a principal 
região de reconhecimento do soro. Dessa forma, não é possível usar exclusivamente a gp43 no diagnóstico sorológico da PCM (LEITÃO et al., 2014).

Para tentar diminuir os resultados falso-positivos dos testes, algumas proteínas vêm sendo usadas em formas recombinantes como antígenos, dentre as quais estão gp43 (CISALPINO et al., 1996), pb27 e pb40 (FERNANDES et al., 2011), Heat-Shock Protein 60 (CUNHA et al., 2002), triosefosfato isomerase (PEREIRA et al., 2004) e formamidase (BORGES et al., 2005). Entretanto, além da problemática relativa à geração e padronização dos antígenos, permanece a busca por proteínas recombinantes que possam ser reconhecidas por soro de ambos os pacientes infectados por P.brasiliensis ou por P.lutzii.

A busca por proteínas ou peptídeos que possam servir como marcadores em imunodiagnóstico parece ser promissora ao se analisar o secretoma ou sub-proteoma exposto de patógenos (Ql et al., 2013; ZHANG et al., 2008), uma vez que essas porções seriam mais facilmente acessíveis ao hospedeiro e à geração de uma resposta imune.

\subsection{Termotolerância em Fungos}

São estimadas cerca de 1,5 milhão de espécies de fungos extantes na Terra, com aproximadamente 70 mil espécies descritas formalmente na literatura. Apesar dessa diversidade, apenas cerca de 300 espécies de fungos foram descritas como patogênicas para humanos e, excetuando os fungos dermatófitos, as infecções fúngicas em humanos são raras. Em virtude dessa raridade, algumas doenças fúngicas importantes como criptococose, blastomicose e histoplasmose foram descritas ao final do século XIX, ao passo que doenças infecciosas importantes causadas por vírus e bactérias, como tuberculose, varíola e peste bubônica, já eram conhecidas há centenas de anos(CASADEVALL, 2005). A ocorrência de micoses sistêmicas em humanos começou a aumentar expressivamente a partir da segunda metade do século XX, com a emergência de doenças imunossupressoras como a AIDS e o desenvolvimento de terapias imunossupressoras para o transplante de órgãos e o tratamento de câncer(CASADEVALL, 2005, 2012). Assim como em humanos, as infecções fúngicas em outros mamíferos e em aves também são raras, com ocorrências mais perigosas ao hospedeiro em situações de imunossupressão ou de baixa temperatura corpórea, em relação à temperatura corporal média desses animais(CASADEVALL, 2012).Notrabalho de Robert e Casadevall(2009), após examinar o crescimento de cerca de 4.800 espécies fúngicas, em diferentes temperaturas, foi observado que a partir de $30^{\circ} \mathrm{C}$, o número de espécies que conseguiam crescer nos meios de cultura diminuiu $6 \%$ a cada grau elevado de temperatura. Além disso, a $40^{\circ} \mathrm{C}$,temperatura corporal média de aves e temperatura de febre elevada em mamíferos, menos de $40 \%$ das espécies fúngicas conseguiram crescer nos meios (Figura 2). 


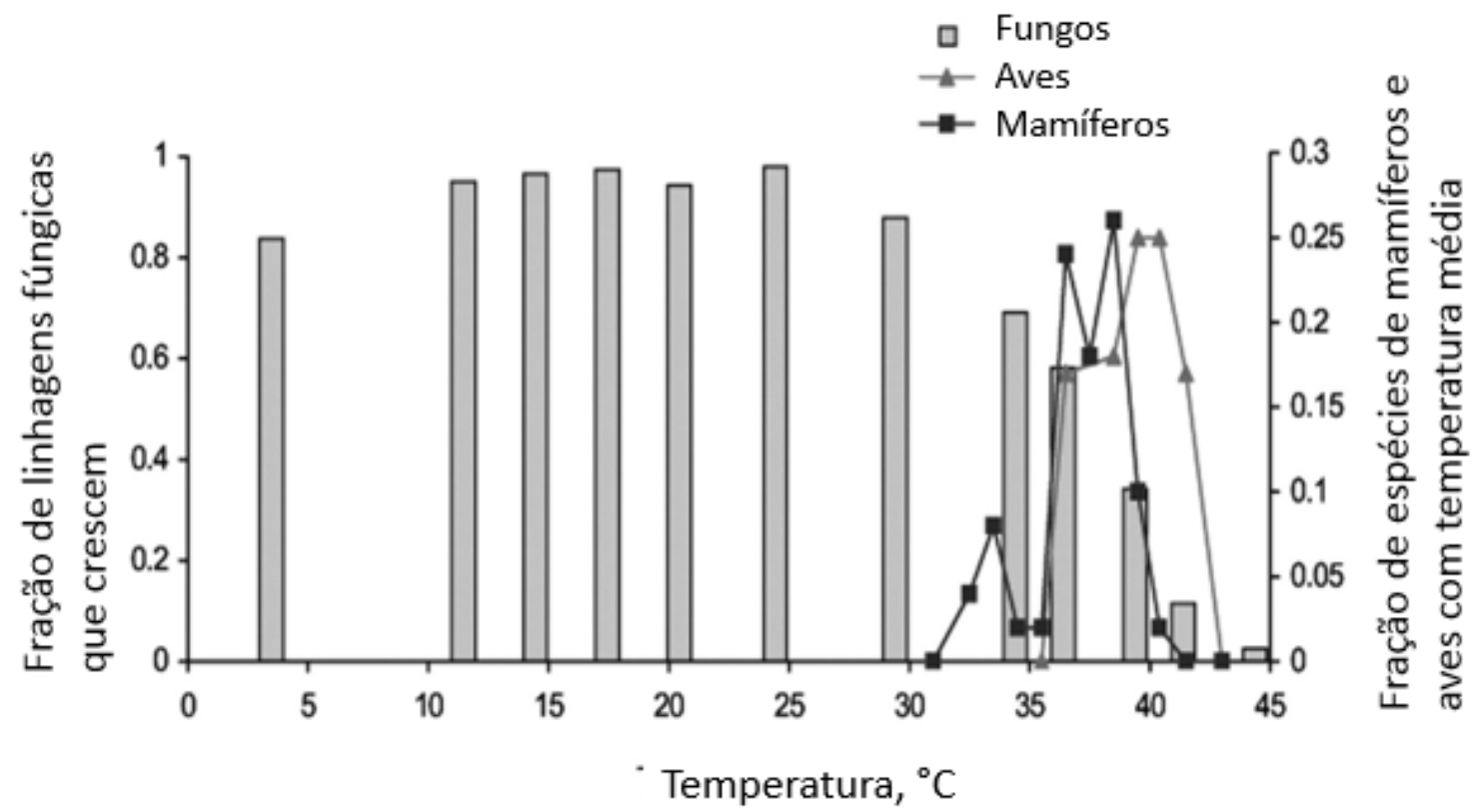

Figura 2. Frações de crescimento de espécies fúngicas por temperatura. As linhas representamfrações de animais cujas temperaturas médias correspondem às do eixo X. Retirado de(ROBERT; CASADEVALL, 2009).

Como exemplos mais pontuais desse fenômeno, encontram-se infecções comumente letais em ornitorrincos (Ornithorhynchus anatinus) por Mucor amphibiorum, um fungo que normalmente infecta anfíbios e é incapaz de crescer em meios de cultura acima de $36^{\circ} \mathrm{C}$, mas que consegue infectar o mamífero porque sua temperatura corpórea média é de $32^{\circ} \mathrm{C}$ (OBENDORFet al., 1993). Além disso, morcegos de diversas espécies que habitam os Estados Unidos ou a Europa podem apresentar infecções pelo fungo Geomyces destructans após períodos de hibernação, nos quais a temperatura desses animais cai consideravelmente(GARGAS et al., 2009).Em contraste às aves e aos mamíferos (homeotermos, reguladores de temperatura por fonte interna de calor), organismos pecilotermos (reguladores de temperatura por fontes externas de calor) como invertebrados, anfíbios e plantas, possuem várias espécies de fungos patogênicos associadas a eles. Para plantas e insetos, estimam-se cerca de 270 mil e 50 mil espécies patogênicas de fungos, respectivamente(HAWKSWORTH; ROSSMAN, 1997).De posse destas evidências na literatura, alguns autores acreditam que além dos sistemas imunes, a manutenção de temperaturas a $37^{\circ} \mathrm{C}$ ou superiores nos animais homeotermos representa uma barreira à infecção por fungos e que aqueles capazes de infectar esses animais possuem adaptações 
que os façam tolerar essas temperaturas. Utilizando Saccharomyces cerevisiae como modelo demonstrou-se que dentre as alterações de fungos contra o estresse térmico estão o atraso no ciclo celular, o acúmulo de trealose, mudanças na composição da membrana plasmática e a dinâmica de chaperonas contra a formação de agregados proteicos (VERGHESE et al., 2012).

\subsection{Chaperonas}

"A vida é mantida por um delicado balanço entre contínua síntese e degradação de proteínas. " -Yoshinori Ohsumi, ganhador do Prêmio Nobel em Medicina ou Fisiologia de 2016, durante seu discurso de banquete(NOBELPRIZE.ORG, 2016).

Um dos principais requisitos para a manutenção da vida celular é a manutenção funcional de suas proteínas, seu proteoma. Para essa manutenção ocorrer, é necessário que a célula consiga manter um balanço ótimo entre síntese e degradação de suas proteínas, bem como o dobramento e localização sub-celular corretos, em resposta às diferentes condições ambientais que as células venham a enfrentar. Essa manutenção pode ser chamada de proteostase e ela é o resultado de uma rede de interações entre sistemas de biogênese, degradação e manutenção conformacional de proteínas, a qual é regulada por vias de resposta a diferentes estresses celulares, como a via de resposta ao choque térmico (do inglês, heat shock response, HSR) e a via de resposta a proteínas não-enoveladas (do inglês, unfolded protein response, UPR). Como elemento de coesão entre os sistemas estão as proteínas chaperonas, as quais são capazes de reconhecer proteínas enoveladas incorretamente e de ajudar no enovelamento correto dessas, contribuindo para a sua manutenção conformacional (Figura 3) (KIM et al., 2013). 


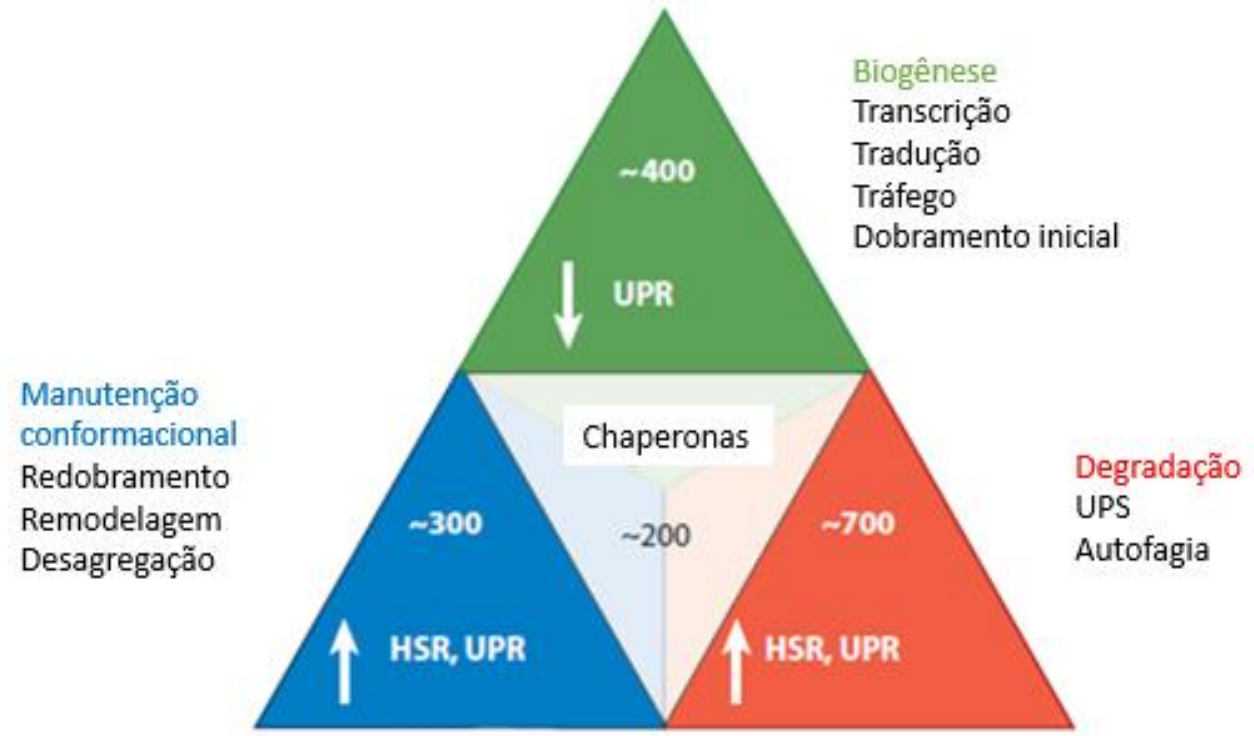

Figura 3. Aproteostase como resultado da interação entre biogênese, degradação e manutenção conformacional das proteínas, com as proteínas chaperonas intermediando esses sistemas. Os números representam estimativas de proteínas para cada sistema em H.sapiens.UPS-Sistema Ubiquitina-proteassoma (do inglês, Ubiquitin-Proteasome response).Adaptado de (KIM et al., 2013).

A manutenção conformacional das proteínas pode ser entendida como um balanço entre estabilidade termodinâmica e flexibilidade conformacional necessária para a função dessas. Dessa forma, as proteínas costumam estar marginalmente estáveis em seus estados nativos e mesmo pequenas perturbações em sua estrutura ou em suas interações com o ambiente podem causar desenovelamento e agregação. Para entender melhor esse processo, é necessário entender o que faz as proteínas terem sua conformação(KIM et al., 2013).

A partir de um estudo de Anfisen(1961), o qual demonstrou que uma ribonuclease poderia se renaturar in vitro, sem o auxílio de outras proteínas, a literatura vem mostrando que boa parte da informação necessária para o enovelamento correto das proteínas está contido em sua própria estrutura primária, por meio de interações não-covalentes, em sua maioria, entre seus próprios resíduos de aminoácido ou de resíduos de outras proteínas. Dentre as interações importantes para esse processo, destacam-se as interações hidrofóbicas, que levam ao o colapso de resíduos hidrofóbicos para o interior das proteínas.Uma vez que o número de resíduos e de moléculas circundantes às proteínas é muito alto e o número de interações possíveis entre estes componentes também é, o caminho de conformações entre a síntese e o enovelamento das proteínas torna-se complexo e heterogêneo. Uma forma de se representar os caminhos de conformações é através de um funil de energia-livre, pelo qual diferentes conformações são representadas por pontos, que formam superfícies irregulares, representando as diferentes barreiras termodinâmicas, as 
quais afunilam em poucos pontos de energia livre baixa (Figura 4). Esses fundos nos funis representam conformações energeticamente favoráveis, as quais podem ser funcionais ou não. As conformações estáveis não funcionais são aquelas que não permitem às estruturas maleabilidade necessária para o exercício de suas funções, como agregados ou fibras amiloides. Essas estruturas estão relacionadas com o desenvolvimento de diversas doenças, como Alzheimer e Parkinson, e com morte celular. Assim as células desenvolveram os sistemas de proteostase, onde as chaperonas impedem os percursos termodinâmicos associados à formação de agregados e ajudam outras proteínas a percorrerem os caminhos associados às suas formas nativas (KIM et al., 2013).

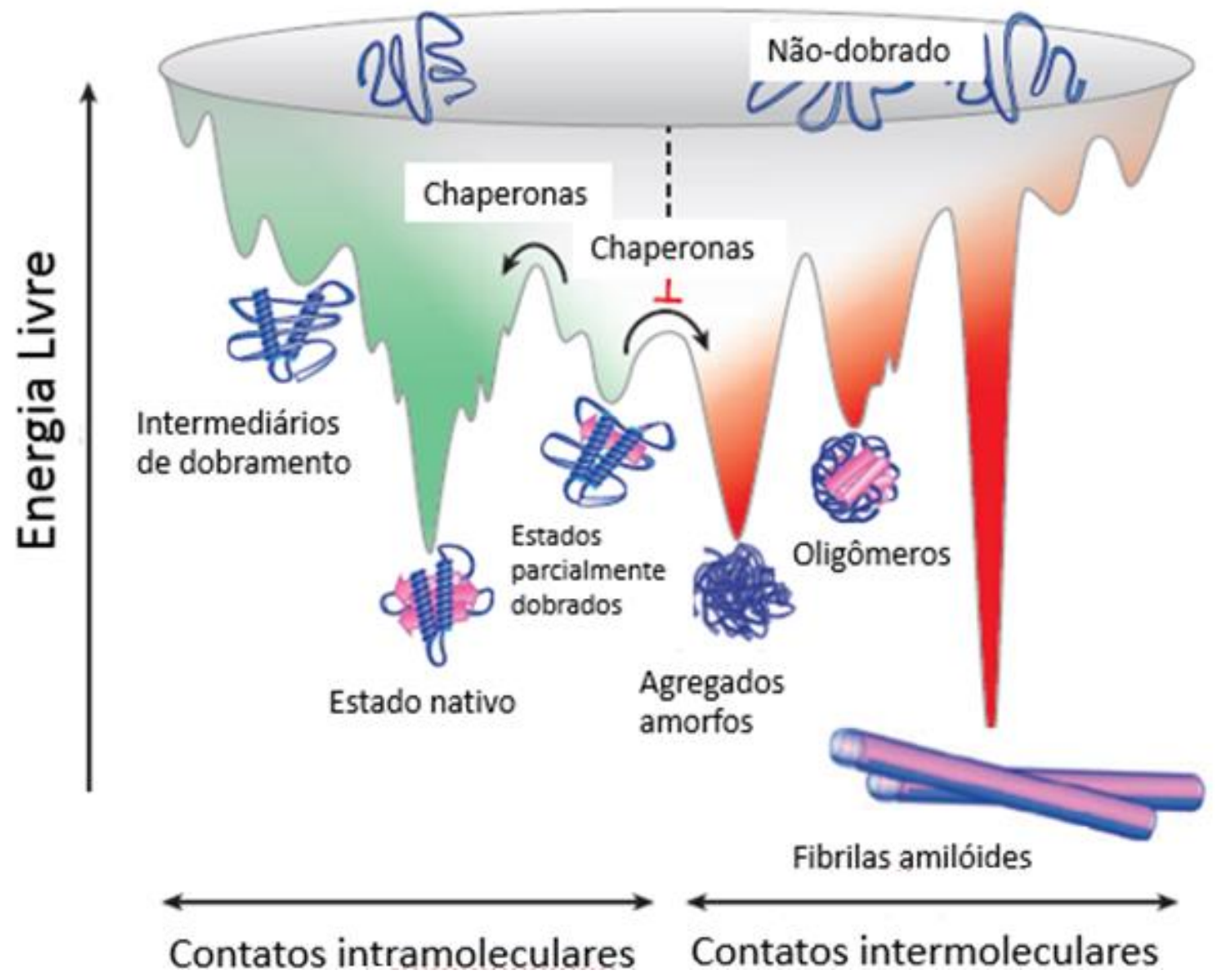

Figura 4. Funil de energia livre esquematizando caminhos irregulares, energeticamente favoráveis entre proteínas recém-sintetizadas e nativas ou agregadas, mostrando o papel de chaperonas no processo. Retirado de (KIM et al., 2013).

O principal grupo de proteínas chaperona está contido na família das Heat-shock Proteins (HSPs). Já que essas proteínas ajudam a manter a forma de outras, estas participam de diversos processos celulares. As HSPs são classificadas com base em suas massas 
moleculares, grosso modo, proteínas de baixo peso molecular $(<37 \mathrm{kDa})$, chamadas de small heat shock proteins (sHSPs) e as demais (>37kDa) de HSPs. As sHSPs compartilham um domínio " $\alpha$-crystallin" e costumam atuar como "Holdases", isso é, estabilizam proteínas-cliente por meio de interações hidrofóbicas, de forma a evitar a formação de agregados, sem depender de moléculas carreadoras de energia, como ATP. Já as outras HSPs costumam atuar como "Foldases", ou seja, modificam ativamente a conformação de outras proteínas, dependendo de moléculas carreadoras de energia, como ATP. Interações sinergísticas entre Holdases e Foldases são comuns e, por vezes, necessáriaspara a manutenção da forma de proteínas-cliente (HASLBECK et al., 2005; VERGHESE et al., 2012). Em fungos, tanto $S$. cerevisiae(VERGHESE et al., 2012) quanto P.brasiliensis(NICOLAet al., 2005)e outras espécies(TIWARI et al., 2015), as HSPs pertencem são o grupo de chaperonas melhor caracterizado.Trabalhos anteriores de transcriptoma do $P$. brasiliensis indicam que há um acúmulo de mRNAs de chaperonas HSP40, HSP60, HSP70, HSP90, HSP100, bem como as sHSPs e outras chaperonas como 14-3-3, calnexina e immunophilinas na fase leveduriforme do fungo (FELIPE et al., 2005; NICOLA et al., 2005). Além disso, esse aumento também é observado em mRNAs de chaperonas, como a HSP90 e HSP70, durante a transição termodimórfica e durante estresse oxidativo(DA SILVA et al., 1999; NICOLA et al., 2008). No entanto ainda resta muito a saber como chaperonas auxiliam esses organismos em sua sobrevivência.

\subsection{Translationally Controlled Tumor Protein (TCTP)}

A proteína TCTP foi identificada como tal pela primeira vez em 1989, após seu cDNA ter sido clonado a partir de um tumor humano e sua expressão ser regulada no nível traducional (BOMMER; THIELE, 2004; NAGANO-ITO; ICHIKAWA, 2012). Essa proteína também possui outras denominações, como fator de liberação de histamina (do inglês, histamine releasing factor, HRF), fortilin, P21, P23, TPT-1, Q23 (NAGANO-ITO; ICHIKAWA, 2012) e Mmi1 (RINNERTHALER et al., 2013), as quais comumente são relacionadas à massa molecular ou à função de interesse dos autores.

Essa proteína é presente em eucariotos e sua estrutura primária, secundária e terciária é altamente conservada (BOMMER; THIELE, 2004; HINOJOSA-MOYA et al., 2008) (Figura 5 e Figura 6). No entanto, ela é regulada por diferentes estímulos ambientais, como citocinas, fatores de proliferação celular, estresses ambientais e outros, além de possuir várias funções, como inibição de apoptose por diferentes mecanismos, indução de liberação de histamina em basófilos e estimulação de proliferação de linfócitos B (BOMMER; THIELE, 2004; NAGANOITO; ICHIKAWA, 2012) (Figura 7). 
Estrutura secundaria

S. pombe

P.sativum

C.elegans

D.melanogaster

M.musculus

H. sapiens

Paracoccidioides app.

Estrutura secundaria

S. pombe

P. aativum

C.elegans

D.melanogaster

M.musculus

H. sapiens

Paracoccidioides spp.

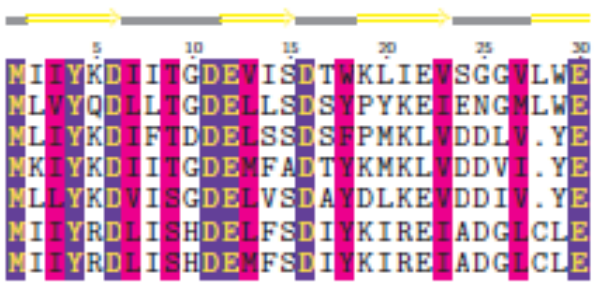

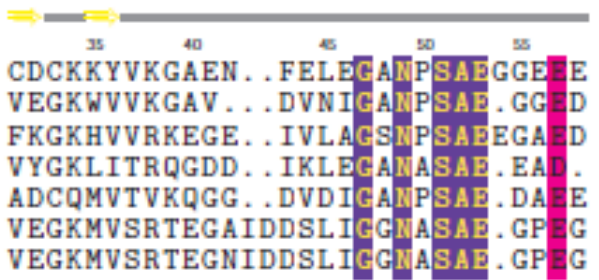

Estrutura secundaria

S. pombe

P.sativum

C.elegans

D.melanogaster

M.musculus

H. sapiens

Paracoccidioides spp.

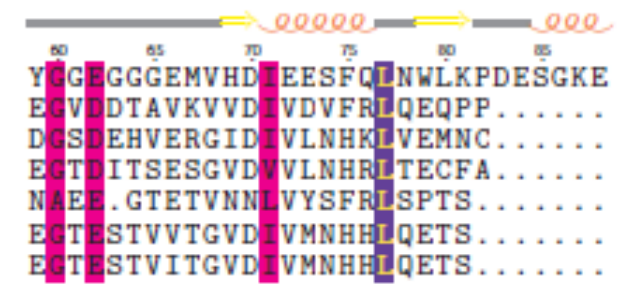

Estrutura secundaria

S. pombe

P. sativum

C.elegans

D.melanogaster

M.musculus

H. sapiens

Paracoccidioides spp.
Estrutura secundaria

S. pombe

P.sativum

C.elegans

D.melanogaster

M.musculus

H. sapiens

Paracoccidioides spp.

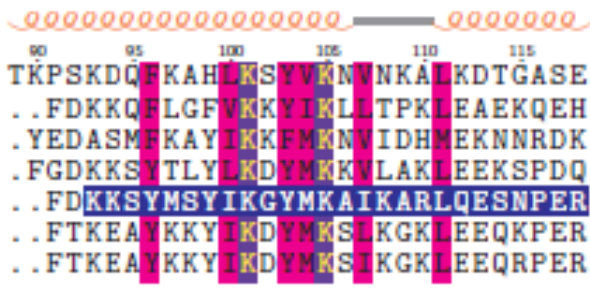

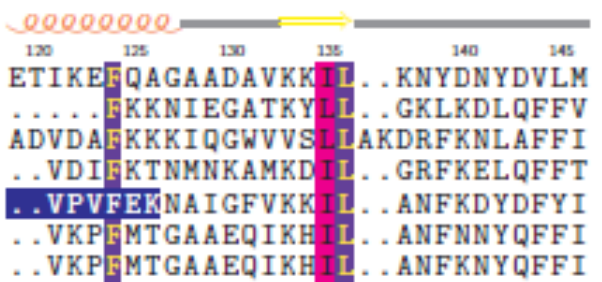



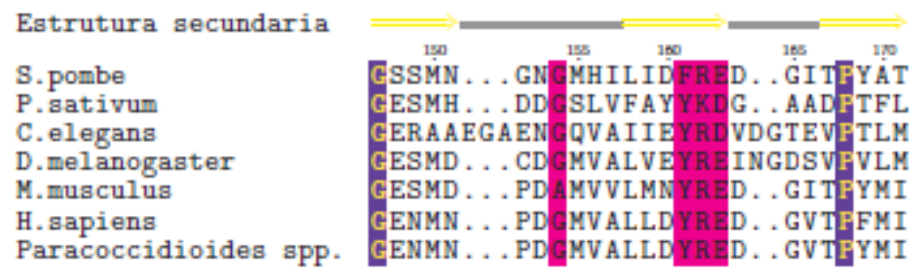

\begin{tabular}{|c|c|c|}
\hline Estrutura secundaria & & \\
\hline S. pombe & I WKH & VPEKV \\
\hline P.sativum & YFSF & KEIKC \\
\hline C.elegans & LVKE & IEEKC \\
\hline D.melanogaster & FFKH & EEBKC \\
\hline M.musculus & FFKD & VSEKF \\
\hline H.sapiens & FFKD & EMEKC \\
\hline Paracoccidioides spp. & FFKD & KMEKC \\
\hline
\end{tabular}

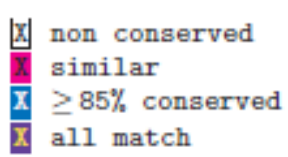

Figura 5. Alinhamento múltiplo feito pelo programa ClustalO (SIEVERS et al., 2011), editado pelo programa Texshade (BEITZ, 2000), entre sequências TCTP de diversos organismos: levedura de fissão(Schizosaccharomyces pombe, Uniprot ID:Q10344),ervilha (Pisum sativum,P50906), nemátodo (Caenorhabditis elegans, Q93573, mosca-das-frutas (Drosophila melanogaster, Q9VGS2), camundongo (Mus musculus, P14701), homem (Homo sapiens, P13693) e Paracoccidioides (NCBI Protein ID EEH41005). Estão destacados em roxo os resíduos idênticos entre as espécies e em rosa aqueles que são semelhantes em seis das sete espécies. Em azul na sequência de M.musculus, está destacado o domínio de ligação a cálcio determinado para essa proteína. Acima das sequências, a estrutura secundária da proteína de H.sapiens está esquematizada, com estruturas em laranja representando hélices- $\alpha$, estruturas em amarelo representando folhas beta e estruturas em cinza representando laços. Para a estrutura secundária, foi utilizado o programa Strider (FRISHMAN; ARGOS, 1995),. Para a estrutura secundária de proteínas TCTP citosólicas, ver (BOMMER; THIELE, 2004). Figura adaptada de (BOMMER; THIELE, 2004).

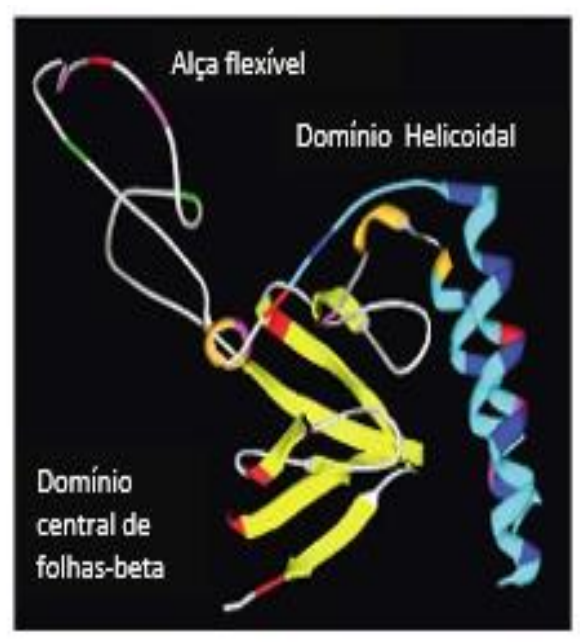

Figura 6. Estrutura terciária da TCTP de S.pombe(THAW et al., 2001). Retirado de (BOMMER; THIELE, 2004). 


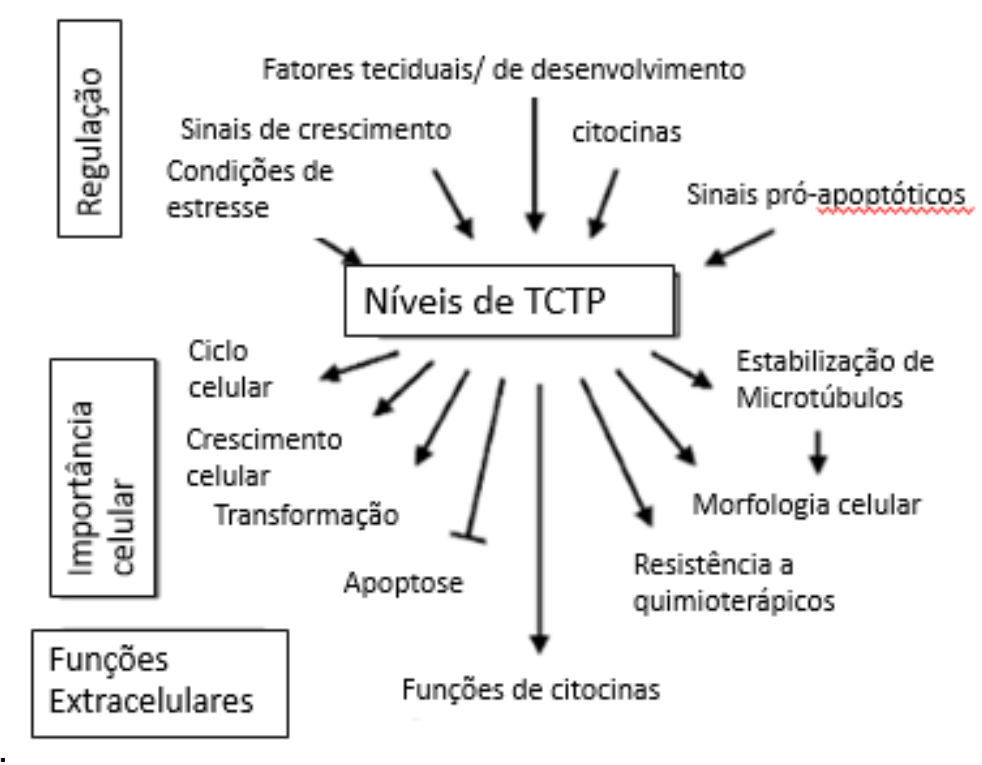

Figura 7.Esquema resumindo parcialmente a regulação e funções da proteína TCTP. Retirado de (BOMMER; THIELE, 2004)

No contexto do gênero Paracoccidioides, a conservação da TCTP, a qual possui estrutura primária idêntica entre as espécies do gênero, além de ser secretada pela levedura de $P$. lutzii(WEBER et al., 2012), a tornam um alvo interessante para o imunodiagnóstico da PCM. No trabalho de Weber e colaboradores (2012), a proteína TCTP foi sugerida pelos autores como um possível fator de proteção do fungo contra estresses ambientais, principalmente na fase micelial. Além disso, alguns trabalhos na literatura (GNANASEKARet al., 2010; THAW et al., 2001) tem sugerido a função de chaperona responsiva à choque térmico para a TCTP, o que pode significar a presença de uma nova chaperona para esse fungo. Assim, o presente trabalho tem como objetivos analisar o potencial de uso da TCTP em imunodiagnóstico da PCM e suas propriedades de chaperona responsiva a choque térmico.

\section{Objetivos}

\subsection{Geral}

O presente trabalho objetiva avaliar a proteína TCTP do gênero Paracoccidioides como um potencial alvo no imunodiagnóstico da paracoccidioidomicose, bem como sua possível atividade como uma chaperona molecular. 


\subsection{Específicos} proteína.

- Avaliar, in silico, propriedades relevantes para a imunogenicidade e conservação da

-Produzir, por meio de expressão heteróloga, a proteína em organismo procarioto e eucarioto (E.coli e L.tarentolae, respectivamente).

- Testar o potencial de imunodiagnóstico da proteína, por meio de ensaios do tipo ELISA e Western blot.

-Caracterizar propriedades relevantes para a possível função de chaperona da proteína, tais quais a termoestabilidade, por dicroísmo circular eensaios de termotolerância in vivo.

\section{Material e Métodos}

\subsection{Delineamento Experimental}

O presente trabalho é dividido em duas partes: imunodiagnóstico e caracterização funcional. Assim sendo, ele possui um eixo central, onde os experimentos foram feitos de forma a se alcançar ambos os objetivos e eixos secundários, onde os experimentos foram feitos para se alcançar uma das partes. Dessa forma, o desenho experimental pode ser entendido como a figura 8 representada abaixo.

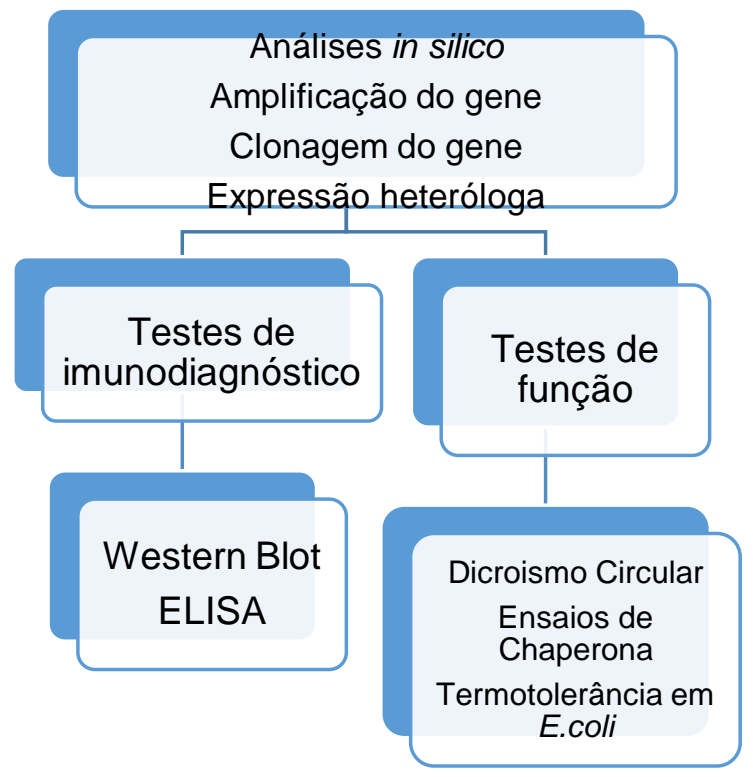

Figura 8. Esquema representativo do delineamento experimental do trabalho. 


\subsection{Prediçõesin silico da proteína}

Para todas as avaliações feitas a seguir, foi utilizada a sequência fasta da proteína TCTP de P. lutzii, cujo número de acesso no banco de dados Protein (NCBI)é XP_002789006. As avaliações feitas sobre essa sequência foram consideradas válidas para as TCTPs do gênero Paracoccidioides, pois a sequência primária depositada para $P$.brasiliensis e P.lutzii é idêntica.O programa TMHMM v2.0 (KROGH A, LARSSON B, VON HEIJNE G, 2001) foi utilizado para a predição de domínios transmembrana e o programa SignalP ( PETERSEN et al., 2011) foi utilizado para a predição de peptídeo sinal, de forma a se avaliar a localização celular da proteína em Paracoccidioides. Ambos os programas foram utilizados com parâmetros padrão. Quanto aos aspectos relevantes à expressão heteróloga em microorganismo eucariotoe ao reconhecimento de epítopos nos testes de imunodiagnóstico, o programa NetPhos v3.1(BLOM et al, 1999) foi utilizado para a predição de sítios de fosforilação, o programa NetNGlyc 1.0 (BLOM et al., 2004) foi utilizado para a predição de Nglicosilações e o programa Bepipred 1.0 (LARSENet al., 2006) foi utilizado para a predição de epitopos lineares para células B. Esses programas foram utilizados com parâmetros padrão (limiar maior ou igual a $p=0,5$ ), exceto pelo Bepipred, o qual teve seu ponto de corte ajustado de 0,35 para 1,3 , de forma a aumentar a especificidade dos resultados. Para se avaliar a similaridade da sequência primária da proteína em relação a seus homólogos em outras espécies fúngicas e em potenciais hospedeiros, como Homo sapiens e Mus musculus, de forma a se identificar a possibilidade de reações cruzadas em testes de imunodiagnóstico, a sequência da proteína TCTP foi alinhada com sequências depositadas no banco Protein (NCBI) por meio do programa pBLAST. Esse alinhamento foi feito utilizando parâmetros padrão, com a exceção do organismo buscado, o qual foi limitado para o reino dos fungos ou H. sapiens ou M.musculus. Em seguida, a sequência FASTA do hit de maior semelhança para cada espécie foi recuperada e então as sequências obtidas a partir de fungos foram alinhadas de maneira múltipla por meio do programa ClustalO(SIEVERS et al., 2011). O mesmo foi feito para a sequência de Paracoccidioides e as sequências de H.sapiens e M.musculus. Para maior clareza dos resultados, os alinhamentos múltiplosforam editados no programa Texshade (BEITZ, 2000).

\subsection{Reação em Cadeia da Polimerase}

A técnica de reação em cadeia da polimerase (do inglês Polymerase chain reaction PCR) foi empregada com primers específicos para o gene TCTP de Paracoccidioides 
brasiliensis (NCBI ref seq. XM_010763848.1). As sequências dos primers estão descritos na tabela 1 e esses foram sintetizados da IDT® (Integrated DNA Technologies). Os amplicons obtidos possuem um tamanho aproximado de 470pb.

Tabela 1.Primers utilizados nas PCRs. Os sítios das enzimas de restrição para as clonagens plasmidiais estão em azul e nucleotídeos adicionados à sequência codanteestão em negrito e o start códon está sublinhado.

\section{Primer Sequência}

\section{$\mathrm{Pb01-}$} 5'-

Ncol

Forward

TTTCCATGGGGATTATCTACAAGGACATCATCAC-3'

Pb02-

5'-TTTGGTACCGACCTTCTCTGGGACGAGAC-3'

Kpnl

Reverse

As reações foram executadas utilizando tampão de reação da Ludwig Biotecnologia Ltda 10X (20 mM Tris- $\mathrm{HCl} \mathrm{pH}$ 8.4, $50 \mathrm{mM} \mathrm{KCl}$ ); 1,5 mM MgCl $2 ; 0,2 \mu \mathrm{M}$ de cada primer; 0,2 mM dNTPs (LGC Biotecnologia) e 0,5 unidades de Taq DNA polimerase (Ludwig Biotecnologia Ltda.) em um volume final de $25 \mu \mathrm{L}$. O DNA molde utilizado foi $1 \mu \mathrm{L}$ de cDNA de micélio de P. brasiliensis Pb18, cedido pela Dra. Lorena Derengowski (FELIPE et al., 2005). O termociclador utilizado foi do modelo LifeTouch Bioer. O programa utilizado está esquematizado abaixo.

$$
40 \mathrm{x}-\left[\begin{array}{l}
95^{\circ} \mathrm{C}-4 \text { minutos } \\
95^{\circ} \mathrm{C}-45 \text { segundos } \\
52^{\circ} \mathrm{C}-30 \text { segundos } \\
72^{\circ} \mathrm{C}-2 \text { minutos } \\
72^{\circ} \mathrm{C}-5 \text { minutos } \\
4^{\circ} \mathrm{C}-\text { ad infinitum }
\end{array}\right.
$$




\subsection{Análises de DNA em eletroforese em gel de agarose}

Os amplicons das PCRs, as extrações de DNA plasmidial e as digestões com enzimas de restrição foram visualizadas em gel de agarose $1 \%(\mathrm{p} / \mathrm{v})$ com brometo de etídio em concentração de $0,5 \mu \mathrm{g} / \mathrm{mL}$ e tampão Tris-Acetato-EDTA (TAE) $1 \times$ (Tris acetato $90 \mathrm{mM} \mathrm{pH} \mathrm{8,0}$ e EDTA 25mM).

\subsection{Clonagem de amplicons em plasmídeo pGEM-tEASY}

Após a obtenção de amplicons com tamanho esperado, esses foram ligados por ação da enzimaT4 DNA ligase à $4^{\circ} \mathrm{C}$ overnight. As concentrações dos reagentes foram de $50 \mathrm{ng}$ de plasmídeo pGEM-tEASY e 1,5 unidades de enzima T4DNA ligase, em um volume final de $10 \mu \mathrm{L}$, contendo tampão de ligação $2 x$ e os amplicons, conforme instruções do fabricante (Promega).

\subsection{Preparo de células termocompetentes}

As linhagens bacterianas utilizadas para as transformações foram E.coli DH5- $\alpha$ (Thermo Fisher Scientific) e E.coli Rosetta pLYss ${ }^{\mathrm{TM}}$. O preparo de células dessas linhagens para a transformação foi feito de acordo com o protocolo descrito por Inoue(SAMBROOK; RUSSEL, 2001a). Uma cultura de $25 \mathrm{~mL}$ em meio de lisogenia (LB, triptona $1 \%(\mathrm{p} / \mathrm{v})$, extrato de levedura $0,5 \%(\mathrm{p} / \mathrm{v}), \mathrm{NaCl} 1 \%(\mathrm{p} / \mathrm{v}))$ foi mantido em crescimento por 12 horas a $37^{\circ} \mathrm{C}$, sob agitação de 180 rpm. Após esse período, volumes de $10 \mathrm{~mL}, 4 \mathrm{~mL}$ e $1 \mathrm{~mL}$ dessa cultura foram inoculadas em $150 \mathrm{~mL}$ de meio LB e essas foram deixadas sob agitação de $200 \mathrm{rpm}$ a temperatura de $18^{\circ} \mathrm{C}$ overnight. No dia seguinte, assim que uma dessas culturas atingisse densidade óptica de 0,6 a 600 $\mathrm{nm}$ (aferida por espectrofotometria no aparelho Ultrospec 1000 da Pharmacia Biotec), essa foi transferida para incubação em gelo por 10 minutos. Após isso, a cultura foi centrifugada a $2.500 \mathrm{xg}$ por 10 minutos a $4^{\circ} \mathrm{C}$. A seguir, o precipitado foi ressuspenso em $48 \mathrm{~mL}$ de tampão TB (10mM HEPES, $15 \mathrm{mM} \mathrm{CaCl}_{2}, 250 \mathrm{mM} \mathrm{KCl}, 55 \mathrm{mM}$ $\mathrm{MnCl}_{2}, \mathrm{pH}$ 6,7). Após nova centrifugação como descrita acima, o precipitado foi ressuspenso em $12 \mathrm{~mL}$ de tampão TB acrescido de DMSO na concentração de $7 \%$ do volume final. Finalmente, a solução resultante foi incubada em gelo por 10 minutos e então distribuída em alíquotas para congelamento em $-80^{\circ} \mathrm{C}$. 


\subsection{Transformação bacteriana}

A transformação das bactérias termocompetentes E.coli DH5-a ou E.coli Rosetta foi feita segundo(SAMBROOK; RUSSEL, 2001b), com pequenas alterações. Para 50 $\mu \mathrm{L}$ de cultura de E.coli, foram acrescentados $5 \mu \mathrm{L}$ da ligação (pGEM-tEASY, pLEXSY-2 ou pET28a) e essa foi incubada em gelo por 30 minutos. Em seguida, as culturas foram expostas a banhomaria a $42^{\circ} \mathrm{C}$ por 90 segundos e novamente incubadas em gelo, por 5 minutos. A seguir, foram acrescidos $250 \mu \mathrm{L}$ de meio SOC $(0,5 \%(\mathrm{p} / \mathrm{v})$ de extrato de levedura, $2 \%(\mathrm{p} / \mathrm{v})$ de triptona, $10 \mathrm{mM}$ de $\mathrm{NaCl}, 2,5 \mathrm{mM}$ de $\mathrm{KCl}, 10 \mathrm{mM}$ de $\mathrm{MgCl}_{2}, 10 \mathrm{mM}$ de $\mathrm{MgSO}_{4}$ e $20 \mathrm{mM}$ de glicose) e as culturas foram incubadas em agitação de $200 \mathrm{rpm}$ a $37^{\circ} \mathrm{C}$ por uma hora. Após esse período, $50 \mu \mathrm{L}$ foram inoculados emplacas de meio LB contendo $50 \mu \mathrm{g} / \mathrm{mL}$ de ampicilina, $40 \mu \mathrm{g} / \mathrm{mL}$ de Xgal e 2,5mM de IPTG (pGEM-tEASY), $50 \mu \mathrm{g} / \mathrm{mL}$ de ampicilina (pLEXSY-2) ou $35 \mu \mathrm{g} / \mathrm{mL}$ de canamicina (pET28a).

\subsection{Seleção de bactérias recombinantes}

Para as bactérias transformadas com plasmídeos pGEM-tEASY, foram selecionadas colônias brancas para o repique em meio LB líquido contendo $50 \mu \mathrm{g} / \mathrm{mL}$ de ampicilina. Após esse inóculo, as culturas foram cultivadas sob agitação de $200 \mathrm{rpm}$ a $37^{\circ} \mathrm{C}$ overnight. Após isso, a presença do inserto nas bactérias transformadas foi confirmada por PCR, conforme descrito anteriormente, com $1 \mu \mathrm{L}$ de cultura no lugar do DNA molde. Para bactérias transformadas com os outros plasmídeos, apenas o cultivo seguido de PCR foi utilizado para confirmação da presença de inserto.

\subsection{Extração de DNA plasmidial}

Para a obtenção de plasmídeos pGEM-tEASY, pLEXSY-2 ou pET28a, culturas de E.coli passaram por preparação em pequena ou média escala. Para pequena escala, foi utilizado o protocolo descrito em(SAMBROOK; RUSSEL, 2001c). Já para média escala, foi utilizado o kitNucleoBond® Xtra Midi (Macherey-Nagel), conforme as instruções do fabricante. 


\subsection{Quantificação de DNA plasmidial}

As amostras resultantes das preparações de DNA plasmidial e as amostras de DNA submetidas à digestão por enzimas de restrição e purificação foram quantificadas por meio de espectrofotometria, no aparelho Nanovue (GE healthcare), utilizando $1 \mu \mathrm{L}$ de amostra.

\subsection{Sequenciamento dos insertos ligados a pGEM-tEASY}

Após as preparações de DNA e quantificação de seus produtos, esses foram diluídos para uma concentração final de $250 \mathrm{ng} / \mu \mathrm{L}$, em um volume final de $5 \mu \mathrm{L}$, e foram enviados para sequenciamento no centro de genômica de alto desempenho do DF, da Universidade Católica de Brasília, em aparelho Sequence Scanner (Applied Biosystems). Para o sequenciamento, foram utilizados primers T7 (forward). Para a análise do sequenciamento, foi utilizado o programa Chromas (http://www.technelysium.com.au/chromas2.html).Após a seleção de sequenciamentos cujos cromatogramas não apresentavam mutações de tipo inserção ou deleção, a sequência resultante foi comparada com a sequência depositada no banco de dados NCBI, por meio do programa nBLAST. Os parâmetros utilizados no nBLAST foram padrão (database Nucleotide Collection (nr/nt), optimize for megablast), exceto pela delimitação de organismo, essa sendo restrita para o gênero Paracoccidioides. Além desse método, as sequências obtidas por sequenciamento foram traduzidas in silico no site http://insilico.ehu.es/translate/ e a sequência correspondente à proteína TCTP foi alinhada com as sequências da proteína de Paracoccidioides spp. utilizando o programa ClustalO, utilizando parâmetros padrão.

\subsection{Digestão por enzimas de restrição de pGEM-tEASY e pLEXSY-2.}

A digestão desses plasmídeos, com ou sem o inserto, foi feita utilizando as enzimas de restrição Ncole Kpnl e com o tampão B5(Jena Bioscience). Para as digestões de pLEXSY2 para a liberação do inserto e sub-clonagem em Pet28a, as enzimas utilizadas fora $\mathrm{Ncol}$ e Notle com tampão B3 (Jena Bioscience). As digestões foram feitas com aproximadamente $26 \mu \mathrm{g}$ de DNA plasmidial e 10 unidades de cada enzima, em um volume final de $60 \mu \mathrm{L}$. As digestões foram incubadas a $37^{\circ} \mathrm{C}$ overnight no aparelho termociclador do modelo LifeTouch Bioer. 


\subsection{Sub-clonagem de inserto em plasmídeos pLEXSY-2 e pET28a}

Os plasmídeos pLEXSY-2 (Figura 9) e pET28a (Figura 10), previamente digeridos e linearizados como descrito acima (sessão 3.12), foram ligados ao inserto TCTP, com o uso de enzima T4 DNA ligase(Promega). As ligações foram feitas em proporções molares de 16:1 inserto-plasmídeo para pLEXSY-2 e de 10:1 inserto-plasmideo para pET28a, de forma que o excesso de insertos em relação aos plasmídeos torne improvável a ligação de plasmídeos sem inserto. A ligação de plasmídeos sem inserto também se torna improvável pela incompatibilidade das extremidades coesivas geradas pelas enzimas de restrição.
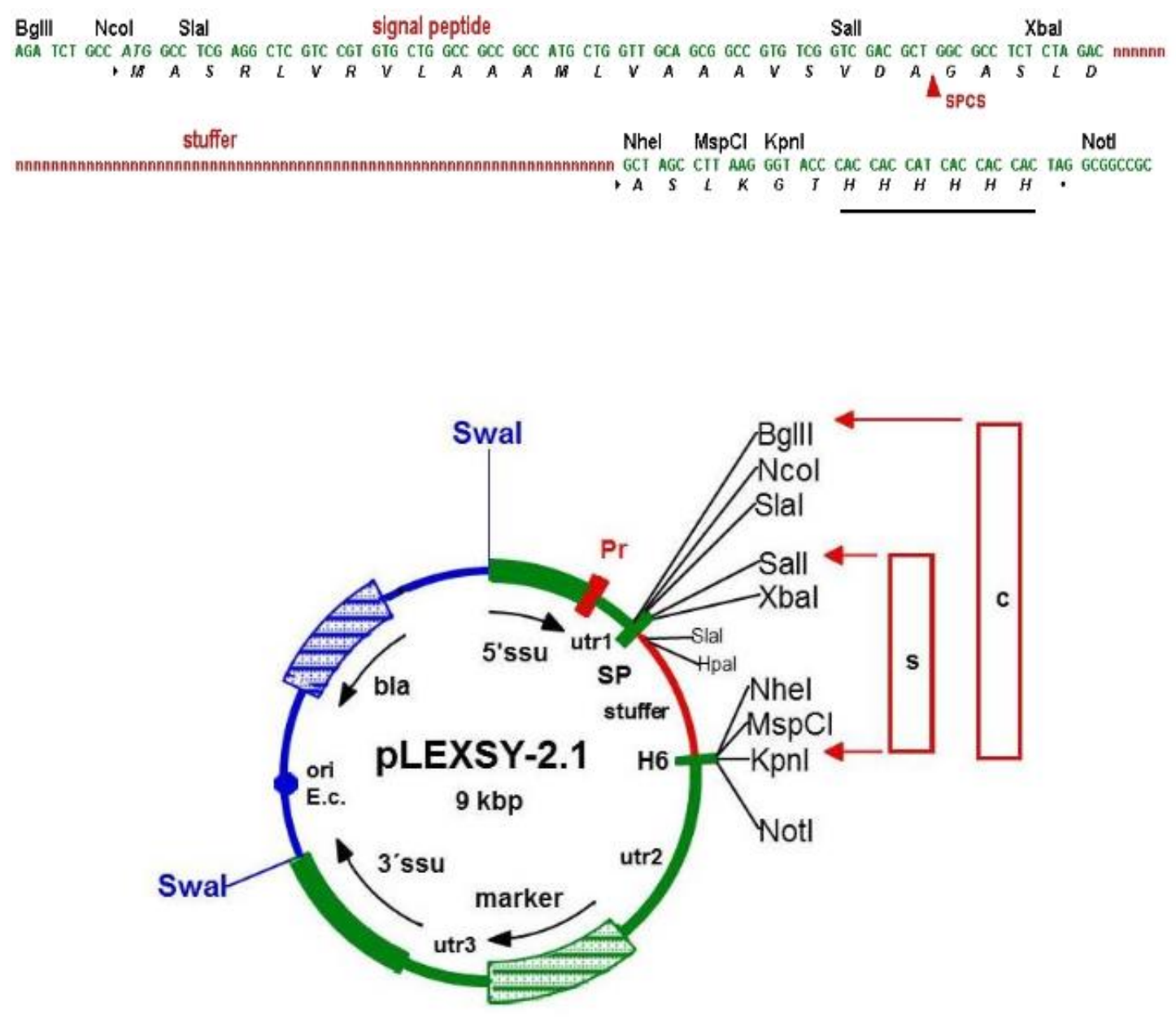

Figura 9. Mapa do plasmídeo pLEXSY-2 com destaque para a região polylinker, onde a região "c" representa expressão citosólica do inserto e a região "s" representa a secreção da proteína expressa, uma vez que a diferença entre essas regiões é a presença de um peptídeo sinal de L.tarentolae. O marcador em verde representa o gene de resistência a geneticina e as regiões 3'ssu e 5'ssu são as regiões de recombinação homóloga do plasmídeo. O marcador em azul "bla" representa o gene de resistência bla, contra antibióticos beta-lactâmicos. Retirado de https://www.jenabioscience.com/images/ae3a4f50f1/EGE-1310.pdf 


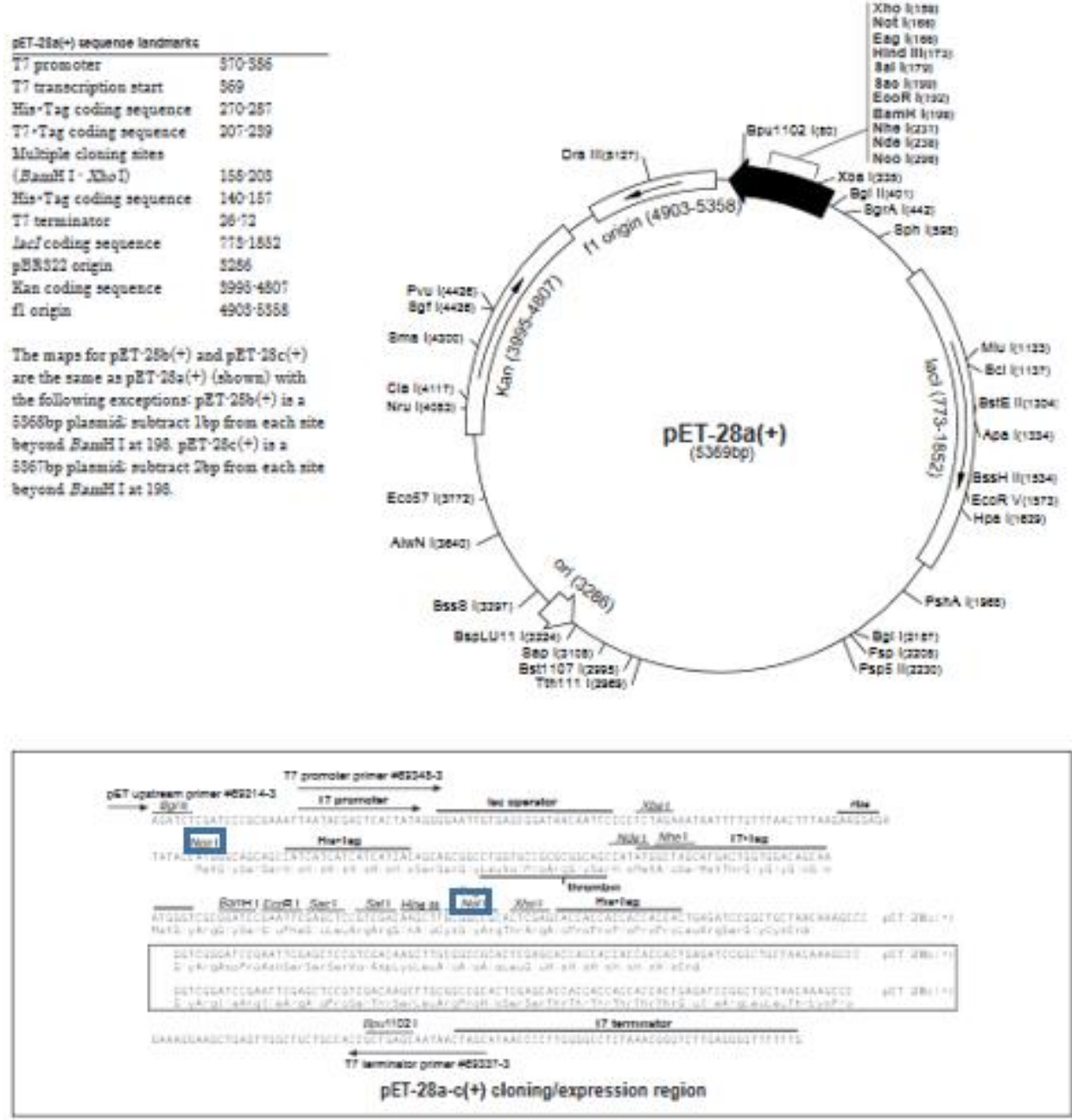

Figura 10. Mapa do plasmídeo pET28a, com destaque para a região polylinker. Sítios de restrição utilizados estão destacados em azul. Retirado de https://www.staff.ncl.ac.uk/p.dean/pET28.pdf

\subsection{Expressão heteróloga em E.coli Rosetta}

Após a transformação de E.coli Rosetta com plasmídeos pET28a ligados ao inserto TCTP, segundo o protocolo descrito acima (sessão 3.7), uma cultura, em meio com $35 \mu \mathrm{g} / \mathrm{mL}$ de canamicina e $33 \mu \mathrm{g} / \mathrm{mL}$ de cloranfenicol, mantida a $200 \mathrm{rpm}$ e a $37^{\circ} \mathrm{C}$, de $5 \mathrm{~mL}$ dessas bactérias foi feita como pré-inóculo. Essa cultura foi cultivadaovernight e $1 \mathrm{~mL}$ dela foi inoculada em $15 \mathrm{~mL}$ de meio LB, com as mesmas concentrações dos antibióticos e condições de crescimento mencionados acima (sessão 3.7). Após aproximadamente duas horas, quando a densidade óptica atingiu o valor de 0,5, a cultura foi induzida a expressar a proteína, pela adição de 0,5mM de IPTG. Paralelamente, o mesmo procedimento foi aplicado a uma 
cultura de E.coli Rosetta cujo plasmídeo pET28a não continha inserto, como controle negativo. Após a indução, amostras das culturas correspondentes aos tempos de 0, 2, 4 e 6 horas foram coletadas, para avaliação do melhor tempo de indução para produção da proteína. Essas amostras foram mantidas a-20 $20^{\circ}$ até análise por SDS-PAGE. Após a determinação do tempo ótimo de indução, foi determinada a solubilidade da proteína em meio hidrofílico utilizando o método a seguir.

\subsection{Sonicação de culturas para a extração proteica}

Após a indução de uma cultura de $15 \mathrm{~mL}$ com o plasmídeo pET28a com o inserto, conforme descrito acima (sessão 3.14), durante um período de 3h, a cultura foi centrifugada a $5.000 \times g$ por 15 minutos. O precipitado foi ressuspenso em solução de lise $\left(12,5 \mathrm{mM} \mathrm{Na}_{2} \mathrm{HPO}_{4}, 12,5\right.$ $\mathrm{mM} \mathrm{NaH}{ }_{2} \mathrm{PO}_{4}, 0,5 \mathrm{M} \mathrm{NaCl}$, pH8,0) e a solução resultante foi incubada em gelo e sonicada em aparelho sonicador (Biolab) aplicando amplitude de 90\%, com valor mínimo de 40\%. Essa sonicação se deu em três períodos de 30 segundos, intercalados por intervalos de 30 segundos. Depois disso, as amostras foram centrifugadas a $12.000 \mathrm{xg}$ por 30 minutos a $4^{\circ} \mathrm{C} \mathrm{e}$ o sobrenadante foi coletado e assinalado como extrato de proteínas solúveis em meio aquoso. O precipitado foi ressuspenso em solução de lise, acrescido de $6 \mathrm{M}$ de uréia, e então foi coletado e assinalado como extrato de proteínas insolúveis em meio aquoso. Os extratos foram mantidos a $-20^{\circ} \mathrm{C}$ até serem analisados via SDS-PAGE.

\subsection{Cultivo e eletroporação em Leishmania tarentolae}

Formas promastigotas de Leishmania tarentolae (Jenabioscience) foram cultivadas em meio BHI (Acumedia, Neogen) suplementado com 0,25\% de Hemina, 1.000 unidades $/ \mathrm{mL}$ de penicilina e $1.000 \mu \mathrm{g} / \mathrm{mL}$ de streptomicina (PenStrep, LifeTechnologies). Esse cultivo foi feito a $26^{\circ} \mathrm{C}$ em ambiente protegido de iluminação. A eletroporação foi feita de acordo com instruções do fabricante (Jenabioscience). Primeiro, um pré-inóculo de $10 \mathrm{~mL}$ contendo $\mathrm{BHI}$ suplementado com Hemina e PenStrep foi incubado em frasco de cultura de células por 72h. Em seguida, esse pré-inóculo foi diluído 1:10 em 10mL de meio com as mesmas características e o crescimento da cultura foi monitorado por espectrofotometria a $600_{\mathrm{nm}}$, da mesma forma em que foi feito para as culturas bacterianas. Uma vez que a OD tivesse atingido um valor que correspondesse a 1,4 na cultura, ou seja de 0,7 em cultura diluída 1:1 com meio, a cultura foi coletada e centrifugada por 3 minutos em 2.000xg a temperatura ambiente. Após centrifugação, o precipitado foi ressuspenso com $2,5 \mathrm{~mL}$ de meio de cultura, de forma a ter $6 \times 10^{8}$ células por $\mathrm{mL}$ e então a cultura resultante foi incubada em gelo por 10 minutos. Ao mesmo tempo, foram introduzidos $20 \mu \mathrm{g}$ de plasmídeo pLEXSY (Jena bioscience) com o 
inserto em $50 \mu \mathrm{L}$ de água destilada e a solução resultante foi incubada em gelo por 10 minutos. Após esses períodos de incubação, $350 \mu \mathrm{L}$ da cultura foram adicionados à solução dos plasmídeos e transferidos para cuvetas de eletroporação de 0,2cm de comprimento (Biorad). Essas cuvetas foram eletroporadas três vezes a $450 \mathrm{~V}$, no modo exponencial do aparelho.Após o pulso, as cuvetas foram incubadas em gelo por 10 minutos. As células que estavam nas cuvetas foram então transferidas para frascos de cultura de células contendo $10 \mathrm{~mL}$ de meio $\mathrm{BHI}$ suplementado com hemina e PenStrep, conforme descrito acima (própria sessão)e a cultura foi mantida a $26^{\circ} \mathrm{C}$ em ambiente protegido de luz. Após $24 \mathrm{~h}$, foi adicionado à cultura $50 \mu \mathrm{g} / \mathrm{mL}$ de geneticina (G418).

\subsection{Extração de DNA total de L. tarentolaee confirmação da presença de inserto}

A extração de DNA total de $L$. tarentolae foi feita conforme descrito anteriormente (MEDINA-ACOSTA; CROSS, 1993), com pequenas alterações. Em síntese, culturas de Leishmania mantidas por $72 \mathrm{~h}$, conforme descrito acima (sessão 3.16), foram coletadas em tubos de $1,5 \mathrm{~mL}$ e centrifugadas a $1.350 \mathrm{xg}$ por 10 minutos. As células precipitadas foram ressuspensas em 150 $\mu \mathrm{L}$ em tampão de TELT (50mM Tris HCl, 62,5mM EDTA, 2,5M LiCl, 4\% Triton $\mathrm{x}-100(\mathrm{v} / \mathrm{v}), \mathrm{pH} 8,0)$ e foram incubadas a temperatura ambiente por 5 minutos. Em seguida, foram adicionados $150 \mu \mathrm{L}$ de clorofórmio e a solução resultante foi homogeneizada vagarosamente a mão. Em seguida, a solução foi centrifugada a $12.000 x g$ por 5 minutos. A seguir, foram adicionados $300 \mu \mathrm{L}$ de etanol absoluto, a mistura foi homogeneizada vagarosamente a mão e incubada por 5 minutos. Depois, a solução foi centrifugada a $12.000 x g$ por 10 minutos. A solução é então lavada uma vez com $1 \mathrm{~mL}$ de etanol absoluto, com centrifugação de $12.000 x$ por 10 minutos e os tubos são colocados para secagem a temperatura ambiente overnight. Finalmente, o precipitado é ressuspenso em água MilliQ. Após a obtenção de DNA por esse método, a presença dos insertos TCTP foi confirmada por PCR, conforme descrito acima (sessão 3.3).

\subsection{Purificação da proteína heteróloga por cromatografia de afinidade por íons metálicos imobilizados (IMAC) de níquel}

Para a purificação da proteína, foi utilizado o kit Ni-NTA agarose (Qiagen), conforme instruções do fabricante, com pequenas alterações. As culturas bacterianas utilizadas para a purificação foram de $300 \mathrm{~mL}$ e seguiram o mesmo protocolo de indução de expressão descrito acima (sessão 3.14).Todos os volumes de soluções mencionados a seguir foram aplicados 
na coluna em partes de $1 \mathrm{~mL}$. A purificação começou com a adição de $1 \mathrm{~mL}$ da matriz Ni-NTA agarose a uma mini-coluna de $3 \mathrm{~mL}$, permitindo a passagem do meio aquoso por gravidade. Em seguida, foram adicionados $2 \mathrm{~mL}$ de solução de lise $\left(12,5 \mathrm{mM} \mathrm{Na} \mathrm{HPO}_{4}, 12,5 \mathrm{mM}\right.$ $\mathrm{NaH}_{2} \mathrm{PO}_{4}, 0,5 \mathrm{M} \mathrm{NaCl}$ e $10 \mathrm{mM}$ imidazol, pH8,0). Depois, foi adicionada a amostra proveniente da sonicação da cultura após indução de expressão (conforme sessão 3.15). Depois, foram adicionados $3 \mathrm{~mL}$ da solução de lavagem (12,5 mM Na $2 \mathrm{HPO}_{4}, 12,5 \mathrm{mM} \mathrm{NaH}_{2} \mathrm{PO}_{4}, 0,5 \mathrm{M} \mathrm{NaCl}$ e $40 \mathrm{mM}$ imidazol, pH8,0). Finalmente, foram aplicados $2 \mathrm{~mL}$ de solução de eluição e $250 \mathrm{mM}$ imidazol, pH8,0). Durante o processo, foram coletadas amostras referentes à cultura sonicada antes da purificação, ao flowthrough da amostra sonicada na coluna, a cada $\mathrm{mL}$ de lavagem e todo o flowthroughresultante da aplicação da solução de eluição, para avaliação em SDSPAGE, sendo este último guardado para análises funcionais da proteína. As purificações foram feitas à temperatura de $4^{\circ} \mathrm{C}$.

\subsection{Análises de proteínas em eletroforese desnaturante de poliacrilamida (SDS-PAGE).}

As análises da expressão, solubilidade e purificação da proteína foram feitas por SDSPAGE desnaturante unidimensional, como descrito a seguir. Amostras provenientes destas etapas foram coletadas, homogeneizadas em tampão de amostra concentrado $5 \times$ (250 mM Tris $\cdot \mathrm{HCl}, \mathrm{pH} 6.8,10 \% \mathrm{p} / \mathrm{v}$ SDS, 50\% (v/v) glicerol, $10 \mathrm{mM} \mathrm{DTT}, 0.05 \% \mathrm{p} / \mathrm{v}$ Azul de bromofenol) e fervidas durante cinco minutos, antes de serem aplicadas nos géis. Os géis possuíram $1 \mathrm{~mm}$ de espessura e suas fases separadoras foram feitas com $15 \%$ de poliacrilamida. Foram aplicados 90V durante a eletroforese da fase concentradora e $180 \mathrm{~V}$ durante a eletroforese da fase separadora. Após o término da eletroforese, os géis foram corados com Coomassie Brilhant Blue R (Sigma).

\subsection{Western Blot}

Amostras oriundas da purificação foram submetidas a SDS-PAGE, conforme descrito acima (sessão 3.19)e, em vez de coradas, foram transferidas a membranas de nitrocelulose, utilizando o sistema miniprotean cell $($ Bio-Rad) e o marcador pré-marcado Novex $®$ sharp PreStained (invitrogen). Essa transferência se deu por 55 minutos em uma corrente de 450mA.Após a transferência, a membrana foi incubada em solução tampão PBST (12,5 mM $\mathrm{Na}_{2} \mathrm{HPO}_{4}, 12,5 \mathrm{mM} \mathrm{NaH} \mathrm{PO}_{4}, 0,5 \mathrm{M} \mathrm{NaCl}$, Tween-20 0,05\% v/v), adicionados a leite desnatado $5,0 \% \mathrm{v} / \mathrm{v}$ (Molico, Nestlé) overnight a $4^{\circ} \mathrm{C}$. Após essa incubação, a membrana foi incubada em PBST por duas horas. Depois, a membrana foi lavada três vezes em PBST e 
incubada em PBST com anticorpo Mouse Anti-his (Life Technologies) diluído1:500 (v/v), para a detecção de caudas de histidina e 1:200 com soro de camundongos infectados experimentalmente, quando foi testada a reatividade da proteína frente os anticorpos dos hospedeiros, por uma hora, sob agitação constante, a temperatura ambiente. Após isso, a membrana foi novamente lavada três vezes com PBST e incubada em PBST com anticorpo secundário Goat Anti-mouse IgG Whole molecule - Alkaline phosphatase antibody (Novex, Life Technologies), diluído 1:1000 (v/v) por uma hora, sob agitação constante, a temperatura ambiente. Depois, a membrana foi lavada três vezes com tampão PBST e então revelada em BCIP/NBT (Sigma), na concentração indicada pelo fabricante. A revelação foi interrompida com água destilada.

\subsection{Ensaio de Imunoabsorbância Enzimática (Enzyme Linked Immunosorbent Assay - ELISA)}

Microplacas de alta afinidade de ligação com fundo plano de 96 poços (Greiner bioone) foram sensibilizadas separadamente com $100 \mu \mathrm{L} /$ poço, contendo $5 \mu \mathrm{g} / \mathrm{mL}$ das proteínas purificadas, em tampão de revestimento (carbonato-bicarbonato) pH 9,6 (30 mM NaHCO 3,15 $\mathrm{mM} \mathrm{Na} \mathrm{CO}_{3}$ ) e incubadas por $12 \mathrm{~h}$ a $4^{\circ} \mathrm{C}$. Em seguida, o excesso de antígeno foi removido por meio de três lavagens com PBST (12,5 $\mathrm{mM} \mathrm{Na}_{2} \mathrm{HPO}_{4}, 12,5 \mathrm{mM} \mathrm{NaH}_{2} \mathrm{PO}_{4}, 0,5 \mathrm{M} \mathrm{NaCl}$, Tween20 0,05\% v/v, Ph 7,4). Os sítios de adesão livres foram bloqueados com 100 $\mu \mathrm{L} /$ poço de PBS pH 7,4 acrescidos de 10\% de SFB (soro fetal bovino, Gibco), seguido por incubação de $1 \mathrm{~h}$ a temperatura ambiente. Ao final, repetiu-se a lavagem. Os soros dos camundongos infectados experimentalmente, cedidos pelo professor Alfredo de Miranda Goes da UFMG(MORAIS et al., 2016), foram diluídos a 1:50, 1:100 e 1:1.000.em PBS/SFB 10\% e adicionados 100 $\mu \mathrm{L} /$ poço, em duplicata. Após incubação de $1 \mathrm{~h}$ a temperatura ambiente, as placas foram novamente lavadas com PBST. O conjugado, composto por anticorposGoat anti- mouse lgG Whole molecule - Alkaline phosphatase antibody (Novex, Life Technologies) foi diluído 1:2.000 em PBS/SFB 10\% e, em seguida, $100 \mu \mathrm{L} /$ poço foram adicionados às placas seguida por incubação de $1 \mathrm{~h}$ a temperatura ambiente, sendo envolvidas por papel alumínio durante essa etapa. Após incubação, o excesso do conjugado foi retirado por três lavagens com PBST. A revelação da reação foi feita pela adição de $50 \mu \mathrm{L} /$ poço de $\mathrm{H}_{2} \mathrm{O}_{2}$ (Dinâmica) em tampão fosfato-citrato $\mathrm{pH}$ 5,0 adicionado de cromógeno OPD (o-Phenylenediamine dihydrochloride Sigma), segundo instruções do fabricante. A reação foi feita em local sob proteção de luz, passados 10 minutos, essa foi interrompida pelo acréscimo de $20 \mu \mathrm{L} /$ poço de $2 \mathrm{~N} \mathrm{H}_{2} \mathrm{SO}_{4}$. A leitura foi feita em espectrofotômetro (BioTeK-Synergy HT) a 490 nm. 


\subsection{Quantificação de proteína}

Para as análises de dicroísmo circular, a quantificação da proteína TCTP em solução foi determinada espectrofotometricamente, utilizando o espectrofotômetro Biochrom Libra $S$ 12 (Biochrom Libra instruments, EUA) em 280nm e aplicando a Lei de Lambert-Beer:

$$
A_{280}=\text { e.l. } C
$$

Equação 1. Lei de Lambert-Beer

Onde, $\mathrm{A}_{280} \mathrm{é}$ a absorbância, em unidades arbitrárias (U.A) a $280 \mathrm{~nm}$, C é a concentração da amostra $\left(\mathrm{mg} \mathrm{mL}^{-1}\right)$, I é o trajeto óptico $(\mathrm{cm})$ da cubeta utilizada e $\varepsilon$ é o coeficiente de extinção molar da proteína $\left(\mathrm{mL} \cdot \mathrm{cm}^{-1} \cdot \mathrm{mg}^{-1}\right)$. A proteína em questão possui $\varepsilon=32430$ em solução aquosa a $280 \mathrm{~nm}$. Esse valor foi calculado pelo programa Protparam (GASTEIGER et al., 2005).

\subsection{Análises de estruturas secundárias e estabilidade estrutural por Dicroísmo Circular}

Medidas de Dicroísmo Circular (CD) foram realizadas em um espectropolarímetro Jasco J-815 equipado com um sistema de controle de temperatura Peltier. Os espectros foram obtidos em uma cubeta de $0,1 \mathrm{~cm}$. As análises foram conduzidas com a proteína TCTP na concentração de $0,150 \mathrm{mg} / \mathrm{mL}$. O tampão utilizado no ensaio foi Tris $\mathrm{HCl}(2 \mathrm{mM}, \mathrm{pH} 7,0)$. As elipticidades $(\theta$, mdeg) obtidas foram convertidas em elipticidade molar $([\theta])$, segundo a equação 2 , e os espectros foram corrigidos com subtração da linha de base do tampão.

$$
[\theta]\left(\mathrm{grau}_{\mathrm{cm}} \mathrm{cm}^{2} \cdot \mathrm{dmol}^{-1}\right)=150 . \alpha /(10 . \mathrm{C} . \mathrm{l})
$$

Equação 2. Equação de conversão de elipticidade em elipticidade molar.

Onde, a é o sinal dicroico (mdeg), C é a concentração da amostra ( $\left.m g \cdot \mathrm{mL}^{-1}\right)$ e l é o trajeto óptico $(\mathrm{cm})$ da cubeta utilizada. A desnaturação térmica foi acompanhada de $25^{\circ} \mathrm{C}$ a $95^{\circ} \mathrm{C}$ e a curva obtida, ajustada com base na fração de proteínas no estado nativo e desnaturado(PACE; M, 1997) e a estabilidade estrutural da proteína caracterizada. O conteúdo de estrutura secundária foi calculado utilizando o programa CDNN 2.1 (BÖHM et al., 1992). 


\subsection{Ensaios de Chaperona}

Para se testar a capacidade de chaperona da TCTP, dois tipos de ensaios foram feitos. No primeiro tipo de ensaio, foi avaliado se a presença da TCTP protege a função de enzimas expostas a condições desnaturantes. No segundo, foi avaliado se a presença da TCTP impede a formação de agregados proteicos, ao se expor uma proteína-alvo a condições nas quais ela forma agregados.

Para o teste de conservação de função, a proteína-alvo utilizada foi a enzima de restrição EcoRl (Jena Bioscience). Seisunidades da enzima foram incubadas com tampão de

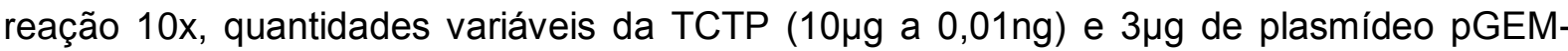
tEASY contendo o gene "mitochondrial ATP-dependent zinc metallopeptidase" de Leishmania infantum (número de referência no banco Nucleotide do NCBI: XM_001468438.1), o qual não apresenta sítios de restrição para a enzimaEcoRI. Dessa forma, uma digestão bem-sucedida da enzima gera duas bandas em gel de agarose $1 \%$ : Uma banda de aproximadamente $3 \mathrm{~kb}$, relativa ao plasmídeo linearizado, e uma banda de aproximadamente $1,8 \mathrm{~kb}$, relativa ao gene. Antes de se incubar a reação para a digestão, período de duas horas a $37^{\circ} \mathrm{C}$, a reação foi incubada a $65^{\circ} \mathrm{C}$ por 20 minutos, condições descritas pela fabricante para a perda total de função da enzima. Depois da reação, as amostras foram analisadas em gel de agarose a $1 \%$.

Para o teste de inibição da formação de agregados, foi utilizada a albumina de soro bovino (do inglês, bovine serum albumine, BSA). A abordagem descrita a seguir é similar a de trabalhos anteriores (HUMPHREYS et al., 1999; POON et al., 2000). Primeiro, foram estabelecidas as condições de agregação da BSA para o ensaio. É sabido que BSA, ao ser reduzida por moléculas como DTT, forma agregados (HUMPHREYS et al., 1999), no entanto, foi preciso estabelecer a concentração ótima de BSA para a execução do experimento. Para isso, diferentes concentrações de BSA $(7,5 \mathrm{mg} / \mathrm{mL}$ a $0,5 \mathrm{mg} / \mathrm{mL})$ em tampão PBS (12,5 $\mathrm{mM} \mathrm{Na}_{2} \mathrm{HPO}_{4}, 12,5 \mathrm{mM} \mathrm{NaH}_{2} \mathrm{PO}_{4}, 0,5 \mathrm{M} \mathrm{NaCl}, \mathrm{pH}$ 7,4, em um volume de $300 \mu \mathrm{L}$ foram incubadas na presença de $20 \mathrm{mM}$ de DTT por quatro horas. A agregação resultante dessa incubação foi monitorada por cinética de absorção a $360_{\mathrm{nm}}$ em aparelho espectrofotômetro Spectramax m5 (Molecular Devices) a cada 5 minutos. Tendo determinado a concentração ótima de BSA, essa concentração foi incubada por quatro horas em PBS pH 7,4 com 20mM de DTT e diferentes concentrações de TCTP $(0,2 \mathrm{mg}$ a $0,05 \mathrm{mg}$ ) em um volume final de $300 \mu \mathrm{L}$ e a absorbância foi monitorada por cinética de absorção a $360_{\mathrm{nm}}$ por espectrofotometria. 


\subsection{Ensaio de Termotolerância em E.coli}

Uma cultura de $15 \mathrm{~mL}$ foi induzida a expressar a proteína heteróloga por três horas, seguindo o protocolo descrito acima (sessão 3.14). Paralelamente, uma cultura controle contendo o vetor pET28a sem o inserto TCTP clonado, correspondente à proteína, passou pelo mesmo protocolo. Após esse período de expressão, foi medida a densidade óptica dessas culturas e essas foram diluídas em tubos de 1,5 mL, de forma que o número de células totais em cada tubo fosse aproximadamente igual, de $10^{8}$ células, correspondente a uma $\mathrm{OD}_{600 \mathrm{~nm}}$ de 1,0. Após isso, tubos provenientes de cada cultura foram submetidos a banhomaria a $50^{\circ} \mathrm{C}$. Durante os tempos de 0,15 e 30 minutos, um tubo oriundo de uma cultura teste e uma cultura controle foi retirado, diluído em série 1:10 em até um fator de diluição de $10^{5} \mathrm{e}$ então cada diluição foi inoculada em volumes de $20 \mu \mathrm{L}$, em placas de meio LB com $35 \mu \mathrm{g} / \mathrm{mL}$ de canamicina, através do método de Miles-Misra (MILESet al., 1938). Cada diluição foi plaqueada em triplicata. Após o inóculo, as placas foram incubadas a $37^{\circ} \mathrm{C}$ overnight e as diluições cujas colônias estavam mais próximas do intervalo de 30-300 foram utilizadas para a contagem de unidades formadoras de colônia (UFCs) por $\mathrm{mL}$ de cultura, segundo a equação:

$$
U F C . m L^{-1}=\bar{N} \cdot C I . F D
$$

Equação 3. Cálculo de Unidades formaduras de colônia por $m L$

Onde $\bar{N}$ é o número médio de colônias em uma dada diluição, $\mathrm{Cl}$ é o valor de correção de inóculo, o qual multiplica o volume do inóculo para que esse corresponda a $1 \mathrm{~mL}$, no caso $\mathrm{Cl}=50$, pois o inóculo era de $20 \mu \mathrm{L} .50=1000 \mu \mathrm{l}$ ou $1 \mathrm{~mL}$ eFD é o fator de diluição.

\subsection{Análises estatísticas}

Os dados quantitativos foram analisados no programa Graphic Pad Prism 5 (Graphpad Software). Para os resultados provenientes dos testes ELISA, cada grupo foi comparado entre os demais por meio do teste ANOVA one-way com pós-teste de Bonferroni. 


\section{Resultados e Discussão}

\subsection{Predições in silico da proteína}

As predições de peptídeo sinal e de domínios transmembrana indicam que a proteína não possui peptídeo sinal, mas é secretada (Figura 11). Este resultado está em conformidade com o que foi encontrado em trabalhos anteriores de secretoma do fungo(WEBER et al., 2012). A aparente contradição entre a ausência de peptídeo sinal e o indício de que a proteína é secretada pode ser explicada por meio de vias alternativas de secreção, comumente usadas por fungos, para lançar proteínas no meio extracelular, como a emissão de vesículas a partir do complexo de golgi ou lisossomos, reciclagem de endossomos, transferência passiva, inversão de membrana, translocalização ou transporte por substrato específico.(KARKOWSKA-KULETA; KOZIK, 2014; NOMBELA et al, 2006).
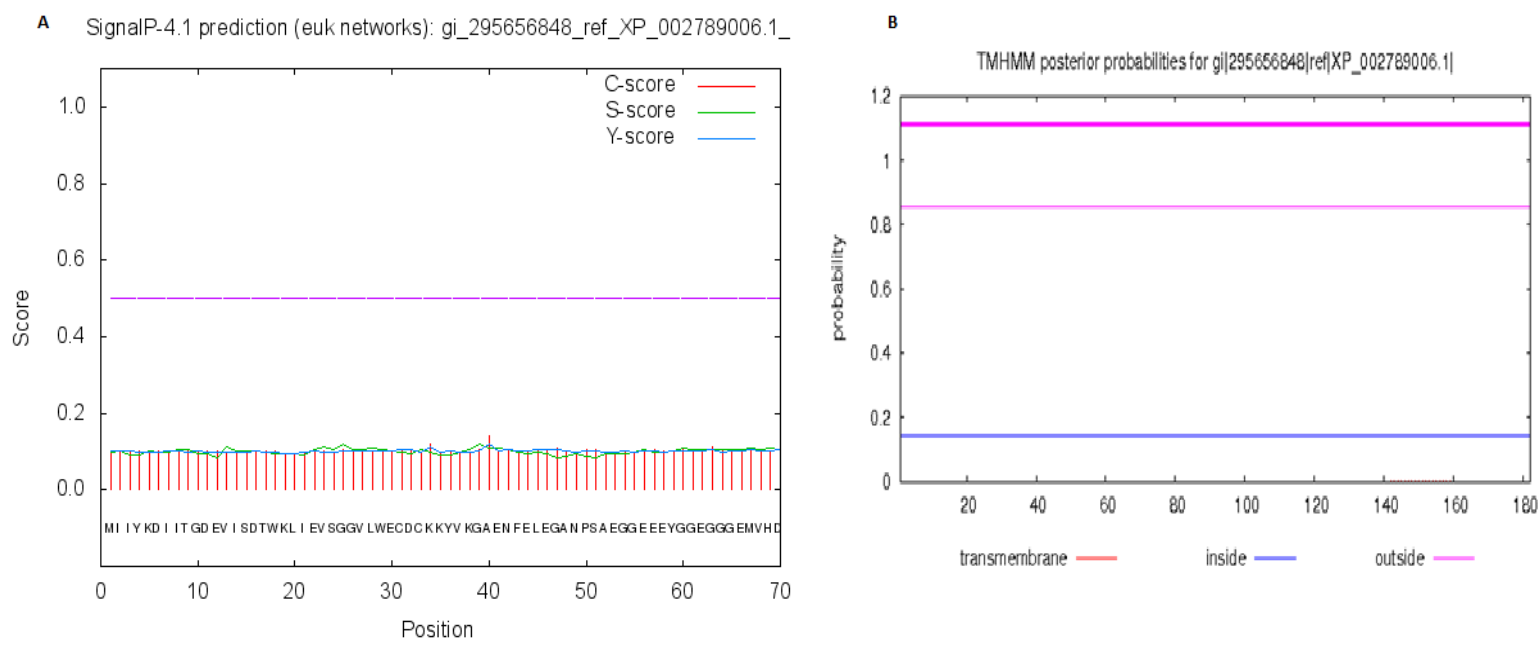

Figura 11. Predição de peptídeo sinal pelo programa SignallP, o qual usa três formas de predição, representadas pelos scores C,S e Y para determinar a presença de peptídeo sinal, caso algum deles ultrapasse o limiar de 0,5 (a) e de domínio transmembrana pelo programa TMHMM, o qual dá a probabilidade, por janelas de sequência, dessa ser interna (azul) ou externa (roxo) à célula ou ainda ser parte de um domínio transmembrana (vermelho) (b).

Foram feitas predições de dois tipos de modificações pós-traducionais, as fosforilações e as glicosilações. Essas modificações pós-traducionais são as mais comuns, ao menos em H.sapiens, e são capazes de afetar o reconhecimento de proteínas pelo sistema imune, seja ao ocultar peptídeos reconhecidos pela resposta imune, seja a essas próprias modificações serem reconhecidas pela resposta imune, por serem diferentes do que se encontra no hospedeiro (JEFFERIS, 2016). No resultado de predição das fosforilações (figura 12), feito no 
programa Netphos2.0, vários sítios de fosforilação foram apontados. Dentre esses sítios estão os resíduos de número 15, 24, 51, 85, 92,102 e 117 (serinas), de número 9, 17, 89, 120, 167 e 171 (treoninas) e de número 4, 36 e 59 (tirosinas). As estruturas de TCTPs depositadas no banco PDB (Protein Data Bank) foram obtidas em E.coli, tornando a comparação das predições com as modificações preditas inviável. No caso do Paracoccidioides, um dos fatores de reações-cruzadas nos testes de imunodiagnóstico é a presença de antígenos com galactose, que é uma modificação comum a vários fungos (ALBUQUERQUEet al., 2005; NEVES et al., 2003), fazendo a predição de glicosilações importante. Em relação aos resultados da predição de N-glicosilações (Figura 13), foi predito um sítio, correspondente à asparagina de posição 49 na estrutura primária.Essa glicosilação é improvável, como o programa indica, pois ao lado do sítio encontra-se uma prolina, que pode causar choque estérico com as glicosil-transferases. A predição de glicosilação foi limitada apenas aos ligados a nitrogênio pois esse é o tipo de glicosilação que a $L$. tarentolae é capaz de fazer.

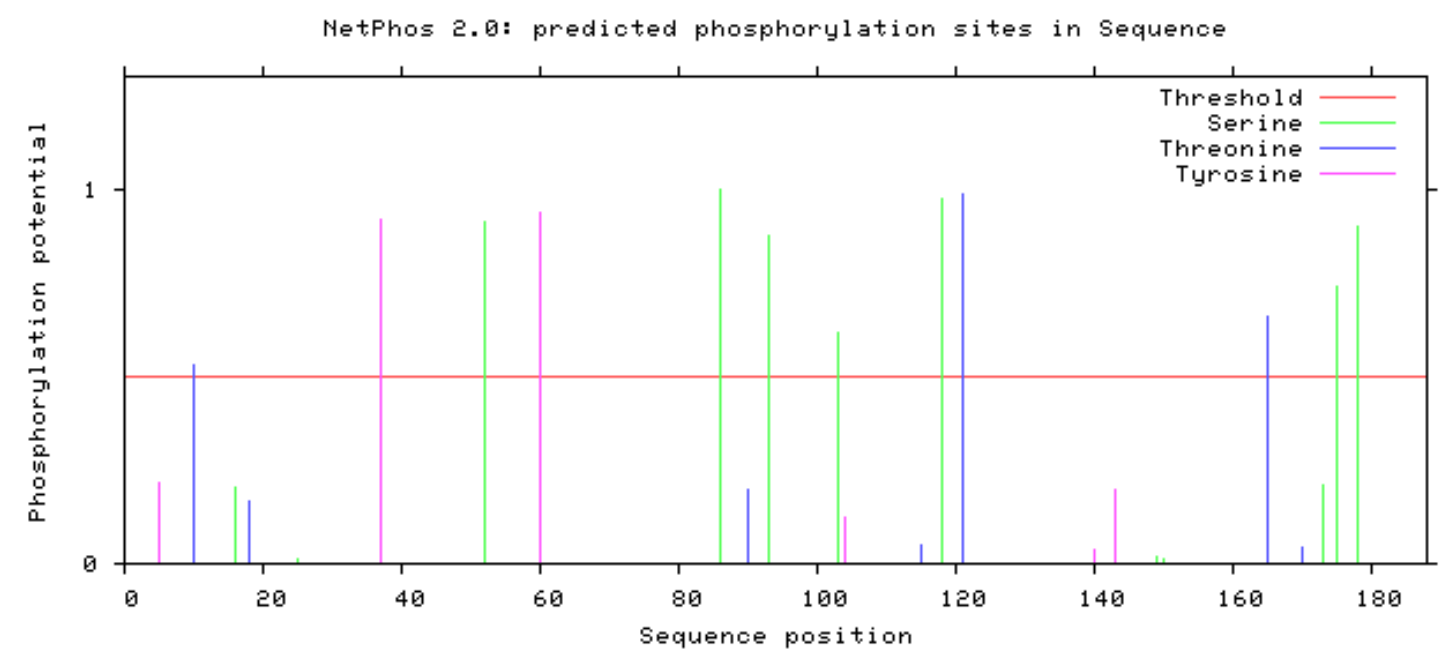

Figura 12. Predição de fosforilações sobre a proteína TCTP pelo programa Netphos, no qual as linhas em verde representam resíduos de serina, as linhas em azul representam os resíduos de treonina e os resíduos em rosa representam os resíduos de tirosina. As linhas de resíduos que ultrapassam o limiar de 0,5 , em vermelho, são apontados como sítios possíveis de fosforilação pelo programa. 


\begin{tabular}{|c|c|c|c|c|c|c|}
\hline SeqName & Position & Potential & $\begin{array}{c}\text { Jury } \\
\text { agreement }\end{array}$ & $\begin{array}{l}\mathrm{N}-\mathrm{Glyc} \\
\text { result }\end{array}$ & & \\
\hline XP_002789006. & $49 \mathrm{NF}$ & 0.5423 & $(6 / 9)$ & + & WARNING : & PRO-X1. \\
\hline
\end{tabular}

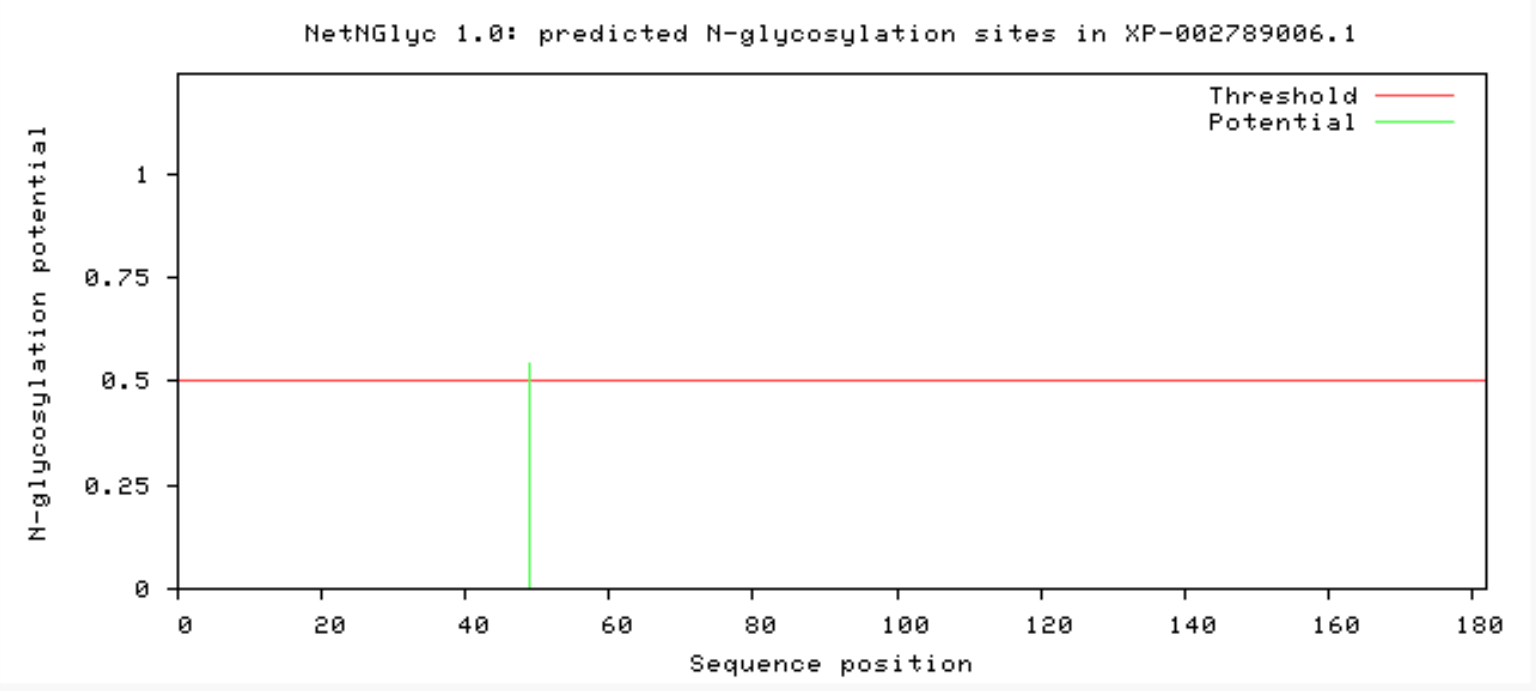

Figura 13. Predição de N-glicosilações pelo programa NetNglyc 1.0, onde a asparagina de número 49 na sequência é apontada como um possível sítio, em verde. Acima do gráfico, encontra-se o valor da predição apontado pelo programa, bem como o aviso de que o próximo resíduo da sequência é uma prolina, o que tornaria difícil a glicosição por choque estérico com a glicosiltransferase.

A predição de epitopos lineares mostra que existem três regiões potencialmente antigênicas, dos resíduos 48 a 64, resíduos 84 a 93 e resíduos 115 a 117 (Figura 14). Dentro da primeira região, havia sido predita a presença potencial de um sítio de glicosilação. Considerando que essa glicosilação venha a existir, ela poderia tornar essa região menos reconhecível pela resposta imune, uma vez que a linhagem de L.tarentolae utilizada foi modificada de forma que suas glicosilações fossem similares a de H.sapiens. O limiar utilizado foi de de 1.3, que de acordo com o grupo que desenvolveu o Bepipred(LARSENet al., 2006), dá às regiões uma especificidade de reação muita alta ( 96\%). Entretanto, os epitopos lineares representam uma porção pequena ( 10\%) dos epitopos totais de células $B$, além de predições desse tipo possuírem baixa capacidade de predição de epitopos reais, uma vez que esses programas usam bancos de dados com milhares de epitopos validados experimentalmente, enquanto que se estimam existir cerca de um trilhão de epitopos (YANG; YU, 2009). A predição baseada em epitopos não-lineares, ditos conformacionais, de células $B$, que representam a maior parte dos epitopos totais para essas células, não foi feita, pois necessitaria da estrutura resolvida da proteína ou de modelagem por homologia com as estruturas de TCTP já resolvidas. 


\begin{tabular}{|c|c|c|c|c|c|c|c|}
\hline seqname & source & feature & start & end & score & N/A & $?$ \\
\hline gi_226295069_gb_EEH5 & bepipred-1.0b & epitope & 48 & 48 & 1.380 & & $\mathrm{~A} \mid \mathrm{E}$ \\
\hline $\mathrm{gi}^{-} 226295069^{-} \mathrm{gb}-\mathrm{EEH} 5$ & bepipred-1.0b & epitope & 49 & 49 & 1.554 & . & $\mathrm{N} \mid \mathrm{E}$ \\
\hline $\mathrm{gi}^{-} 226295069^{-} \mathrm{gb}-\mathrm{EEH} 5$ & bepipred-1.0b & epitope & 50 & 50 & 2.031 & . & $\mathrm{P} \mid \mathrm{E}$ \\
\hline gi_226295069_gb_EEH5 & bepipred-1.0b & epitope & 51 & 51 & 2.111 & . & $S \mid E$ \\
\hline gi_226295069_gb_EEH5 & bepipred-1.0b & epitope & 52 & 52 & 2.287 & . & $\mathrm{A} \mid \mathrm{E}$ \\
\hline $\mathrm{gi}^{-} 226295069^{-} \mathrm{gb}-\mathrm{EEH} 5$ & bepipred-1.0b & epitope & 53 & 53 & 2.332 & . & $\mathrm{E} \mid \mathrm{E}$ \\
\hline 226295069_gb_EEH5 & bepipred-1.0b & epitope & 54 & 54 & 2.245 & . & $\mathrm{G} \mid \mathrm{E}$ \\
\hline gi_226295069_gb_EEH5 & bepipred-1.0b & epitope & 55 & 55 & 2.104 & . & GIE \\
\hline $\mathrm{gi}^{-} 226295069^{-} \mathrm{gb}-\mathrm{EEH} 5$ & bepipred-1.0b & epitope & 56 & 56 & 2.019 & . & $\mathrm{E} \mid \mathrm{E}$ \\
\hline $\mathrm{gi}^{-} 226295069^{-} \mathrm{gb}$ EEH5 & bepipred-1.0b & epitope & 57 & 57 & 2.040 & . & $E \mid E$ \\
\hline gi_226295069_gb_EEH5 & bepipred-1.0b & epitope & 58 & 58 & 2.101 & . & $\mathrm{E} \mid \mathrm{E}$ \\
\hline gi_226295069-gb_EEH5 & bepipred-1.0b & epitope & 59 & 59 & 2.145 & . & $\mathrm{Y} \mid \mathrm{E}$ \\
\hline $\mathrm{gi}^{-} 226295069^{-} \mathrm{gb}$ EEH5 & bepipred-1.0b & epitope & 60 & 60 & 2.158 & . & GIE \\
\hline gi_226295069_gb_EEH5 & bepipred-1.0b & epitope & 61 & 61 & 2.056 & . & $\mathrm{G} \mid \mathrm{E}$ \\
\hline $\mathrm{gi}^{-} 226295069^{-} \mathrm{gb}$ EEH5 & bepipred-1.0b & epitope & 62 & 62 & 1.974 & . & $\mathrm{E} \mid \mathrm{E}$ \\
\hline $\mathrm{gi}^{-} 226295069^{-} \mathrm{gb}-\mathrm{EEH} 5$ & bepipred-1.0b & epitope & 63 & 63 & 1.603 & . & GIE \\
\hline gi_226295069_gb_EEH5 & bepipred-1.0b & epitope & 64 & 64 & 1.419 & . & GIE \\
\hline gi_226295069_gb_EEH5 & bepipred-1.0b & epitope & 84 & 84 & 1.810 & . & $\mathrm{E} \mid \mathrm{E}$ \\
\hline gi_226295069-gb_EEH5 & bepipred-1.0b & epitope & 85 & 85 & 2.207 & . & SIE \\
\hline $\mathrm{gi}^{-} 226295069^{-} \mathrm{gb}$ EEH5 & bepipred-1.0b & epitope & 86 & 86 & 2.293 & . & GIE \\
\hline gi_226295069_gb_EEH5 & bepipred-1.0b & epitope & 87 & 87 & 2.333 & . & $\mathrm{K} \mid \mathrm{E}$ \\
\hline $\mathrm{gi}^{-} 226295069^{-} \mathrm{gb}{ }^{-} \mathrm{EEH} 5$ & bepipred-1.0b & epitope & 88 & 88 & 2.245 & . & $\mathrm{E} \mid \mathrm{E}$ \\
\hline $\mathrm{gi}^{-} 226295069^{-} \mathrm{gb}$ EEH5 & bepipred-1.0b & epitope & 89 & 89 & 2.165 & . & $T \mid E$ \\
\hline $\mathrm{gi}_{226295069^{-g b} \mathrm{EEH} 5}$ & bepipred-1.0b & epitope & 90 & 90 & 2.138 & . & $\mathrm{K} \mid \mathrm{E}$ \\
\hline gi_226295069_gb_EEH5 & bepipred-1.0b & epitope & 91 & 91 & 2.035 & . & $\mathrm{P} \mid \mathrm{E}$ \\
\hline $\mathrm{gi}^{-} 226295069^{-} \mathrm{gb}-\mathrm{EEH} 5$ & bepipred-1.0b & epitope & 92 & 92 & 1.637 & . & $\mathrm{SIE}$ \\
\hline gi_226295069_gb_EEH5 & bepipred-1.0b & epitope & 93 & 93 & 1.461 & . & $\mathrm{K} \mid \mathrm{E}$ \\
\hline $\mathrm{gi} 226295069 \mathrm{gb}$ EEH5 & bepipred-1.0b & epitope & 115 & 115 & 1.306 & . & $\mathrm{G} \mid \mathrm{E}$ \\
\hline $\mathrm{gi}^{-} 226295069^{-} \mathrm{gb}$ EEH5 & bepipred-1.0b & epitope & 116 & 116 & 1.627 & . & $\mathrm{A} \mid \mathrm{E}$ \\
\hline $\mathrm{gi}^{-} 226295069^{-} \mathrm{gb}^{-} \mathrm{EEH} 5$ & bepipred-1.0b & epitope & 117 & 117 & 1.362 & & $\mathrm{SIE}$ \\
\hline
\end{tabular}

Figura 14. Predição de epitopos lineares pelo programa Bepipred. As colunas de start e end representam a janela de sequência utilizada, aqui sendo de um resíduo. A coluna de score representa o valor atribuído a cada resíduo, no caso mostrando todos os resíduos que obtiveram scores superiores ao limiar de 1,3. A coluna delimitada por "?" mostra o símbolo de uma letra de cada resíduo e a letra $\mathrm{E}$ representando uma predição positiva para aquele resíduo.

Os alinhamentos feitos utilizando proteínas TCTP de outros fungos e de potenciais hospedeiros (Figura 15 e Figura 16) mostram que a estrutura primária da TCTP é bastante conservada, assim como literatura anterior indicava (BOMMER; THIELE, 2004; HINOJOSAMOYA et al., 2008). No entanto, algumas regiões são consideravelmente dissimilares, como as regiões entre os resíduos 35 a 44, 57 a 61 e 64 a 87 no alinhamento com $H$. sapiense M.musculus; e as de 18 a 24, 37 a 46,53 a 66 e 82 a 89 no alinhamento de fungos. É interessante notar que a região entre os resíduos 57 a 64 é razoavelmente pouco conservada entre a sequência de Paracoccidioides spp. e as demais em ambos os alinhamentos e está contida na região predita como epitopo linear para células $B$, podendo ser explorada futuramente como alvo em trabalhos de imunodiagnóstico. 
Paracoccidioides spp. Homo sapiens

Mus musculus

consensus

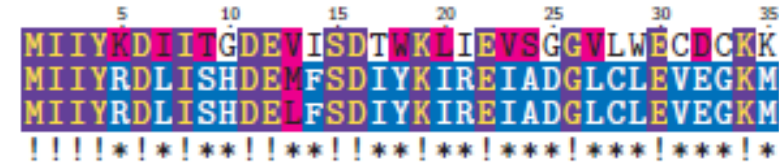

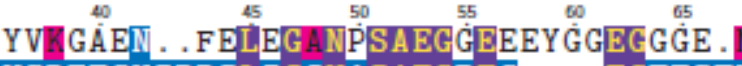
VSRTEGN IDDSLIGGNASAEGPEG . . . . EGTESTV VSRTEGAIDDSLIGGNASAEGPEG . . . . EGTESTV ***********!*!*!*!!!!!*!* ! !*****

Homo sapiens

Mus musculus consensus

Paracoccidioides spp.

Homo sapiens

Mus musculus

consensus

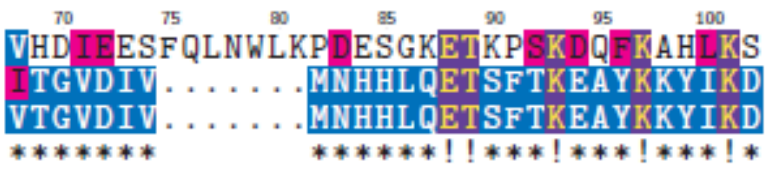

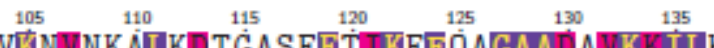

YMKS IKGKLEE. .QRPERVKPFMTGAAEQIKHILA

YMKS L KGKLEE . . QKPERVKPFMTGA AEQIKH ILA

!*!*****!** ***!**! *!**!!! !***! *!!*

Paracoccidioides spp.

Homo sapiens

Mus musculus

consensus

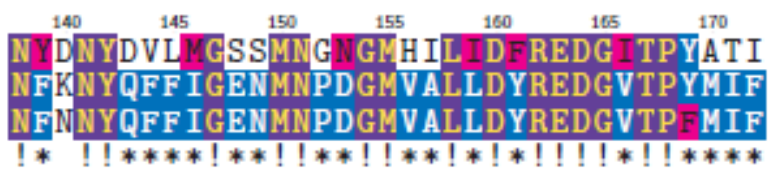

KḦGLVP $\stackrel{180}{175 \mathrm{EKV}}$

FKDGLKMEKC

FKDGLEMEKC

*!*!!*!!*

$\frac{X}{X}$ non conserved
$\frac{X}{\text { similar }}$
$\frac{X}{X} \geq 50 \%$ conserved
$\mathbf{X} \geq 80 \%$ conserved

Figura 15. Alinhamento múltiplo entre TCTP de Paracoccidioides e de Homo sapiens (Genbank ID: EAX08733) e Mus musculus(Genbank ID:BAE35188). 
Paracoccidioides spp.

Talaromyces stipitacus

Talaromyces marneffei

Rasamsonia emersonii

Coccidioides posadasii

Coccidioides immitis

Uncinocarpus reesii

Blastomyces gilchristii

Emmonsia parva

Histoplasma capsulatum

Emmonsia crescens

consensus

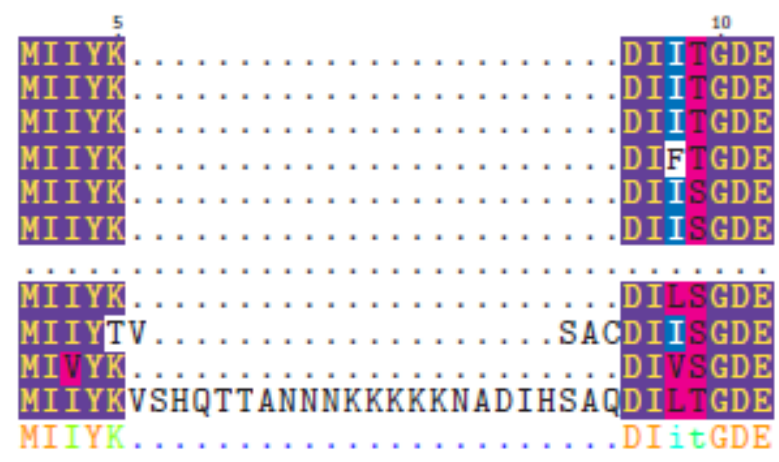

Paracoccidioides spp.

Talaromyces stipitacus

Talaromyces marneffei

Rasamsonia emersonii

Coccidioides posadasii

Coccidioides immitis

Uncinocarpus reesii

Blastomyces gilchristii

Emmonsia parva

Histoplasma capsulatum

Emmonsia crescens

consensus

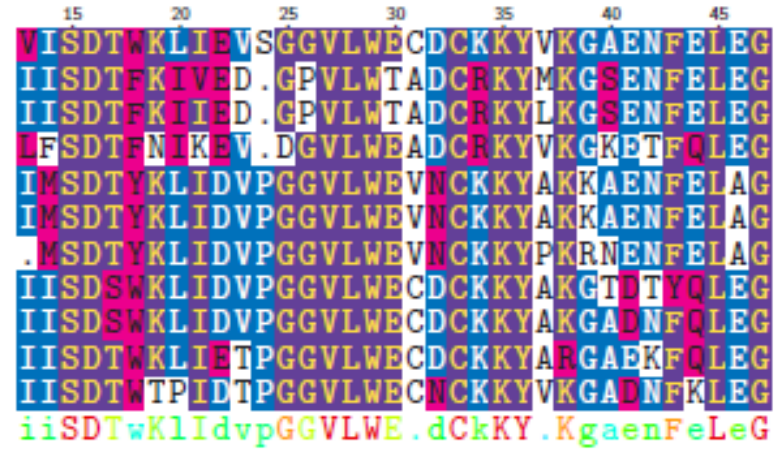

Paracoccidioides spp. Talaromyces stipitacus Talaromyces marneffei Rasamsonia emersonii

Coccidioides posadasii

Coccidioides immitis

Uncinocarpus reesii

Blastomyces gilchristii

Emmonsia parva

Histoplasma capsulatum

Emmonsia crescens

consensus

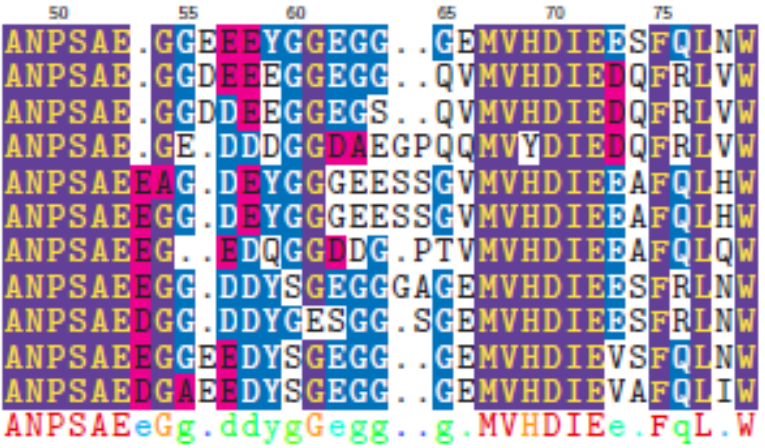


Paracoccidioides spp. Talaromyces stipitacus Talaromyces marneffei Rasamsonia emersonii Coccidioides posadasii Coccidioides immitis Uncinocarpus reesii Blastomyces gilchristii Emmonsia parva

Histoplasma capsulatum Emmonsia crescens consensus

Paracoccidioides spp. Talaromyces stipitacus Talaromyces marneffei Rasamsonia emersonii Coccidioides posadasii Coccidioides immitis Uncinocarpus reesii Blastomyces gilchristii Emmonsia parva

Histoplasma capsulatum Emmonsia crescens consensus

Paracoccidioides spp. Talaromyces stipitacus Talaromyces marneffei Rasansonia emersonii Coccidioides posadasii Coccidioides immitis Uncinocarpus reesii Blastomyces gilchristii Emmonsia parva

Histoplasma capsulatum Emmonsia crescens consensus

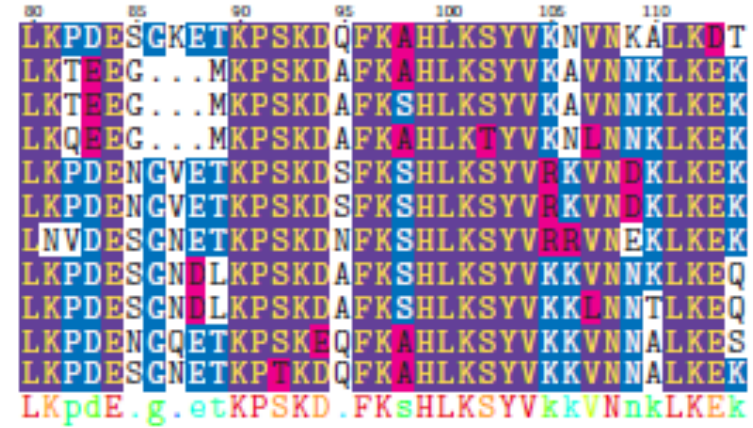

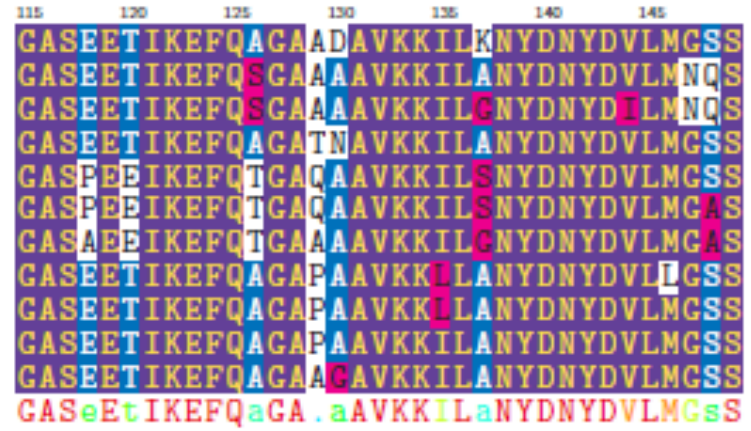

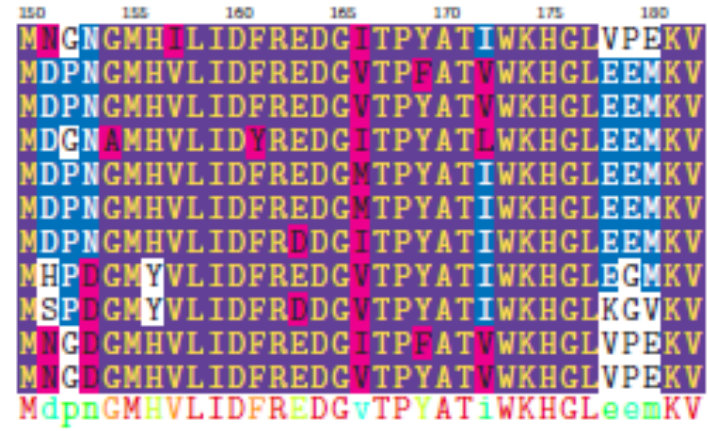

$\mid \underline{y}$ non conserved
similar
$\underline{X} \geq 50 \%$ conserved
$\underline{X} \geq 80 \%$ conserved

Figura 16. Alinhamento múltiplo entre TCTP de Paracoccidioides e proteína de outras espécies fúngicas. Números de acesso das sequências: T.stipitacus XP_002479299 (NCBI ref. seq), T.marneffei KFX48765 (Genbank), R. emersonii XP_013326393 (NCBI ref. seq), C. posadasii XP_003071930 (NCBI ref seq), C. immitis XP_001243543 (NCBI ref seq), U. reesii XP_002543427 (NCBI ref seq), B.gilchristii XP_002622227 (NCBI ref. seq), E. parva KLJ11237 (Genbank), H. capsulatum XP_001541972 (NCBI ref. seq), E.crescens KKZ67430 (Genbank).

\subsection{Reação em Cadeira da polimerase (PCR)}

A reação em cadeia da polimerase com primers direcionados ao gene TCTP de Paracoccidioides spp. foi bem-sucedida, com amplicon entre 400 e $500 \mathrm{pb}$, como esperado, ao 
se utilizar cDNA da fase micelial de Paracoccicioides brasiliensis e utilizando o programa de termociclador descrito na sessão de material e métodos (Figura 17).

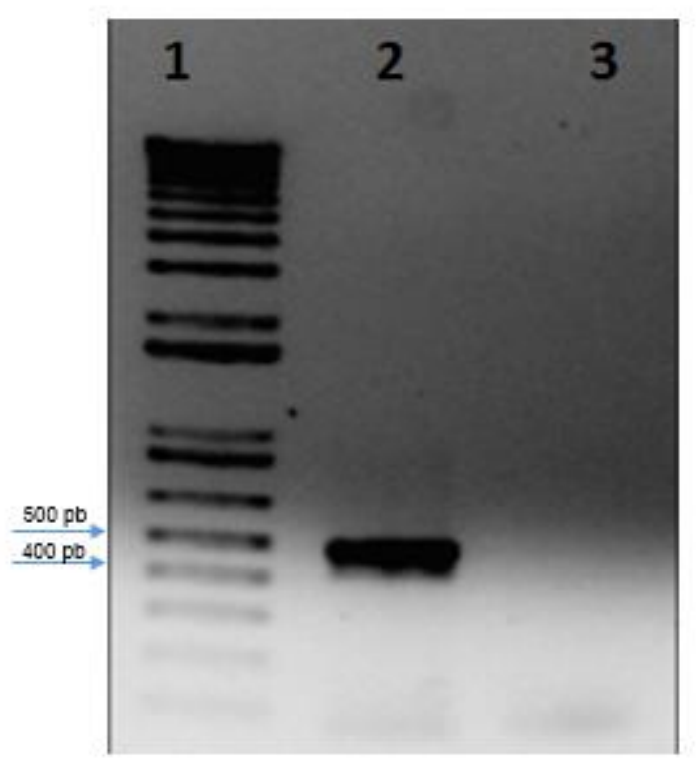

Figura 17. Eletroforese em gel de agarose a $1 \%$ da PCR, apresentando o produto de amplificação do gene. 1- Ladder 1kb (Thermo Fisher Scientific), 2- Amostra oriunda da PCR. 3- Controle negativo

Esse amplicon foi ligado em plasmídeos pGEM-tEASY e os plasmídeos resultantes foram transformados em E.coli DH5a termocompetentes, como descrito na sessão de material e métodos. As colônias foram selecionadas e seus plasmídeos foram extraídos como descrito na sessão de material e métodos. Esses plasmídeos foram enviados para o sequenciamento de seus insertos.

\subsection{Sequenciamento dos insertos ligados a pGEM-tEASY}

As sequências de insertos obtidas a partir do sequenciamento de onze clones foram analisadas para a presença de mutações como descrito em material e métodos. Dentre as sequências obtidas, uma delas apresentou identidade de $99 \%$ com o gene TCTP de Paracoccidioides brasiliensis, sendo a diferença encontrada entre as sequências de uma substituição de timina por citosina na posição 19 da sequência.(Figura 18). Essa mudança pode ter sido resultado de um erro de polimerização da Taq polimerase ou pode estar naturalmente presente na sequência molde.Além disso, ao se fazer o alinhamento múltiplo entre a proteína codificada pelo inserto e as proteínas de Paracoccidioides spp., a única mudança observada entre elas é a inserção de uma glicina após o primeiro resíduo da 
proteína a ser codificada pelo inserto (Figura 19). O códon correspondente a essa glicina foi inserido no desenho de primers, uma vez que a enzima de restrição escolhida para o corte em 5' foi a Ncol, cujo sítio de clivagem (C/CATGG) utiliza o start códon do gene e que adicionaria uma guanina à sequência, causando um deslocamento na fase de leitura em um nucleotídeo. Assim, outras duas guaninas foram adicionadas à sequência, codificando uma glicina, a qual é um aminoácido pequeno e que julgamos não interferir de maneira significativa nas propriedades físico-químicas da proteína, uma vez que se trata de um único aminoácido cuja cadeira lateral é composta por um átomo de hidrogênio.

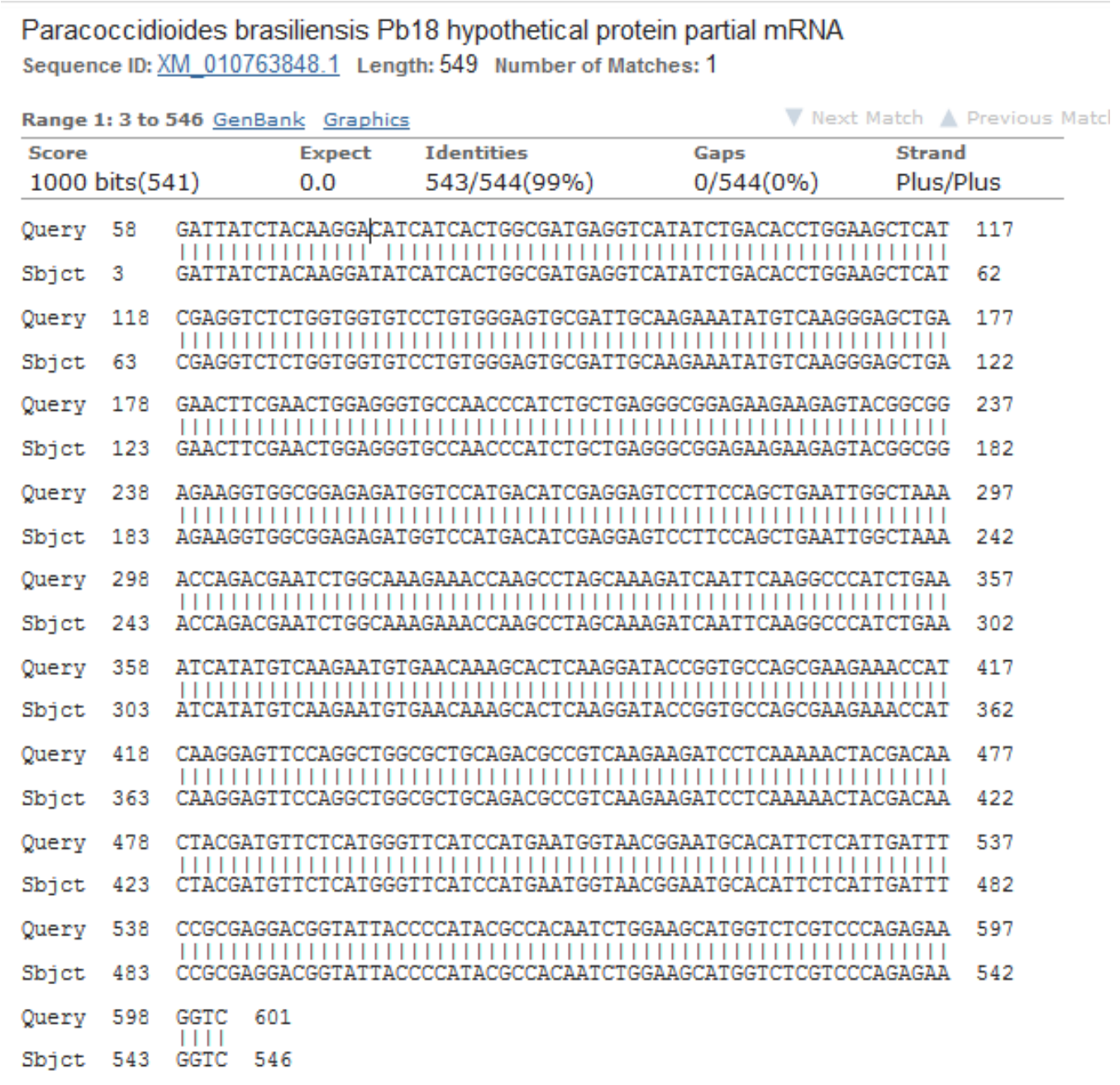

Figura 18. Alinhamento, via nBLAST, entre a sequência obtida a partir do sequenciamento e a sequência de Paracoccidioides brasiliensis depositada no banco nucleotide do NCBI, a partir do terceiro nucleotídeo da sequência "Query". Os nucleotídeos anteriores foram comparados com a sequência molde manualmente, uma vez que o nBLAST os retirou do alinhamento. O stop códon e a cauda antihis estão presentes no plasmídeo pET28a e por isso não aparecem nesse alinhamento. 


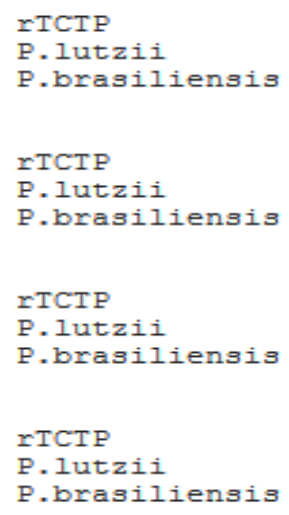

GGEGGGEMVHDIEESFQLNWLKPDESGKETKPSKDQFKAHLKSYVKNVNKALKDTGASEE GGEGGGEMVHDIEESFQLNWLKPDESGKETKPSKDQFKAHLKSYVKNVNKALKDTGASEE GGEGGGEMVHDIEESFQLNWLKPDESGKETKPSKDQFKAHLKSYVKIVNKALKDTGASEE

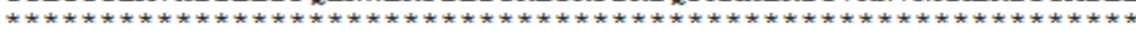

I IKEFQAGAADAVKKI LKNYDNYDVLMGSSMNGNGMHILIDFREDGITPYAT IWKHGLVP I IKEFQAGAADAVKKI LKNYDNYDVLMGSSMNGNGMH I I I FREDGIT PYAT IWKHGLVP I IKEFQAGAADAVKKI LKNYDNYDVLMGSSMNGNGMH I L I DFREDGITPYAT IWKHGLVP

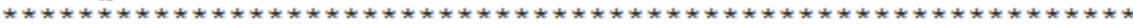

Figura 19. Alinhamento múltiplo entre a proteína codificada pelo inserto TCTP e as proteínas TCTP de Paracoccidioides spp.

\subsection{Sub-clonagem de inserto em plasmídeos pLEXSY-2 e pET28a}

Após a análise do sequenciamento, os plasmídeos que continham este inserto analisado acima (sessão 4.3) foram digeridos com as enzimas de restrição $\mathrm{Ncol}$ e $\mathrm{Kpnl}$ e esse inserto foi sub-clonado em pLEXSY-2. O plasmídeo resultante foi transformado em E.coli $\mathrm{DH} 5 \alpha$ e as culturas que tiveram a presença do inserto confirmada, por PCR, tiveram seus plasmídeos extraídos. Esses plasmídeos foram digeridos com as enzimas de restrição Ncole Notl e os insertos resultantes foram sub-clonados em plasmídeos pET28a, os quais foram transformados em E.coli DH5a e posteriormente em E.coli Rosetta, linhagem de expressão heteróloga. Essa estratégia foi utilizada para a geração de plasmídeos de expressão em $L$. tarentolae e E.coli sem muitas etapas adicionais e o sítio de Notl em pLEXSY-2 está logo depois do stop codon, o que, combinado com a inserção do inserto por meio do corte em 5' por $\mathrm{Ncol}$ permite a tradução do inserto sem a presença de nucleotídeos que não pertençam à sequência deste, gerando assim uma proteína de alta similaridade de estrutura primária com a proteína expressa em sistemahomólogo.

\subsection{Expressão heteróloga em E.coli Rosetta}

Após a transformação da linhagemE.coli Rosetta com o plasmídeo pET28a contendo ao inserto TCTP, culturas dessa linhagem foram induzidas a expressar a proteína ao serem incubadas com IPTG. O resultado, apresentado em gel SDS-PAGE (Figura 20), mostra que a proteína é melhor expressa após duas a quatro horas de indução, uma vez que esses dois tempos possuem bandas mais intensas nas eletroforeses SDS-PAGE de tamanho esperado para a proteína. 


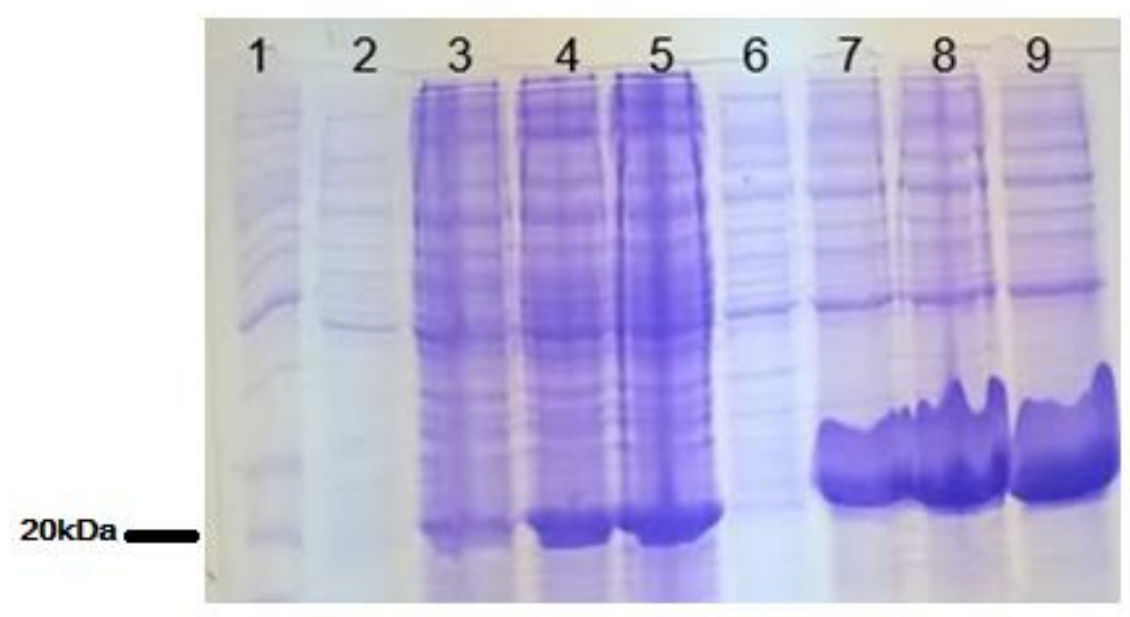

Figura 20.Eletroforese em gel SDS-PAGE $0,75 \mathrm{~mm}$ a $12 \%$ de acrilamida com amostras de colônias de E.coli Rosetta pET28a sem inserto TCTP (controle negativo, poços 2 a 5) e E.coli Rosetta pET28/TCTP induzidas a expressar TCTP (poços 5 a 9) em diferentes intervalos de tempo. 1- Ladder "benchmark" (Thermoscientific). 2- Controle negativo 0 h após estímulo, 3-Controle negativo após $2 \mathrm{~h}$, 4- Controle negativo após 4h, 5- Controle negativo após 6h, 6- Cultura teste 0 h após estímulo,7- Cultura teste após 2h, 8- Cultura teste após 4h,9-Cultura teste após $6 \mathrm{~h}$.

Em seguida, ao observar a eletroforese em gel SDS-PAGE contendo amostras com e sem uréia (Figura 21), percebe-se que a proteína está mais abundante no meio aquoso sem uréia, assim foi determinado que a proteína é solúvel em meio aquoso, em concordância com a literatura(SEO; EFFERTH, 2016). Na altura da proteína heteróloga, cerca de 20kDa, estão localizadas duas bandas. Essas bandas poderiam ser dímeros, de tamanho ligeiramente diferente, ou artefatos da técnica. Depois da análise as amostras de purificação (Figura 22) em gel mais concentrado ( $15 \%$ de acrilamida), observa-se apenas uma banda, o que parece indicar tratar-se de um artefato. 


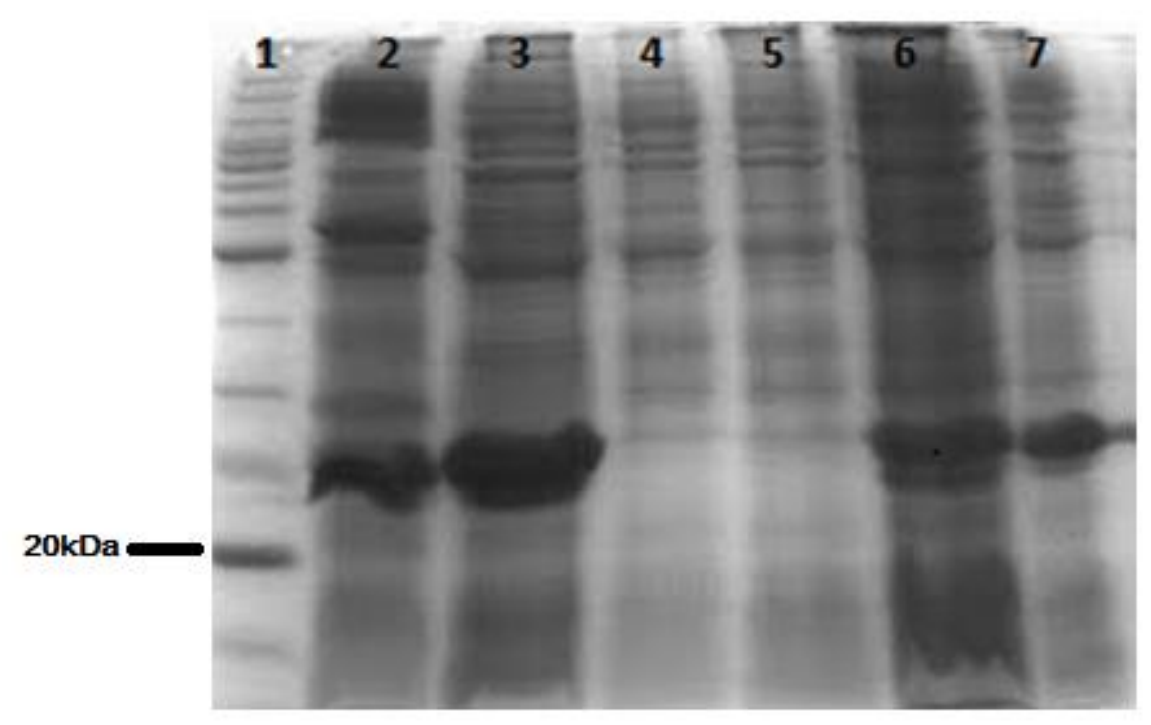

Figura 21. Eletroforese em gel SDS-PAGE $0,75 \mathrm{~mm}$ a $12 \%$ de acrilamida de porção solúvel e insolúvel de precipitado de colônias de E.coli Rosetta pET28/TCTP induzidas a expressar TCTP, após sonicação (sessão 3.15). Também possui amostras de pellets de indução em diferentes intervalos de tempo. 1Ladder "benchmark" (Thermoscientific). 2-Porção insolúvel, 3-Porção solúvel, 4- Controle negativo (E.coli sem plasmídeo), 5- Controle negativo (Pet/TCTP sem indução com IPTG), 6- Cultura teste $2 \mathrm{~h}$ após estímulo, 7- Cultura teste após 3h.

Tendo determinado o tempo de expressão e a solubilidade da proteína, culturas maiores, de $300 \mathrm{~mL}$, foram induzidas para a purificação da proteína, durante um período de três horas, período médio de expressão ótima da proteína. Ao se analisar um gel SDS-PAGE contendo amostras das etapas da purificação (Figura 21), observamos que a proteína é purificada em quantidades razoáveis e que o método requer poucas lavagens para retirar proteínas bacterianas da coluna. No entanto, o processo de lavagem não foi otimizado, uma vez que a proteína heteróloga é observada em fases de lavagem, o que pode ser feito melhorado futuramenteao se utilizar mais matriz Ni-NTA na coluna, diminuindo o volume da cultura induzida, utilizando uma concentração menor de imidazol nas lavagens (a concentração de imidazol utilizada nas lavagens foi de $40 \mathrm{mM}$ ), dentre outras formas. 


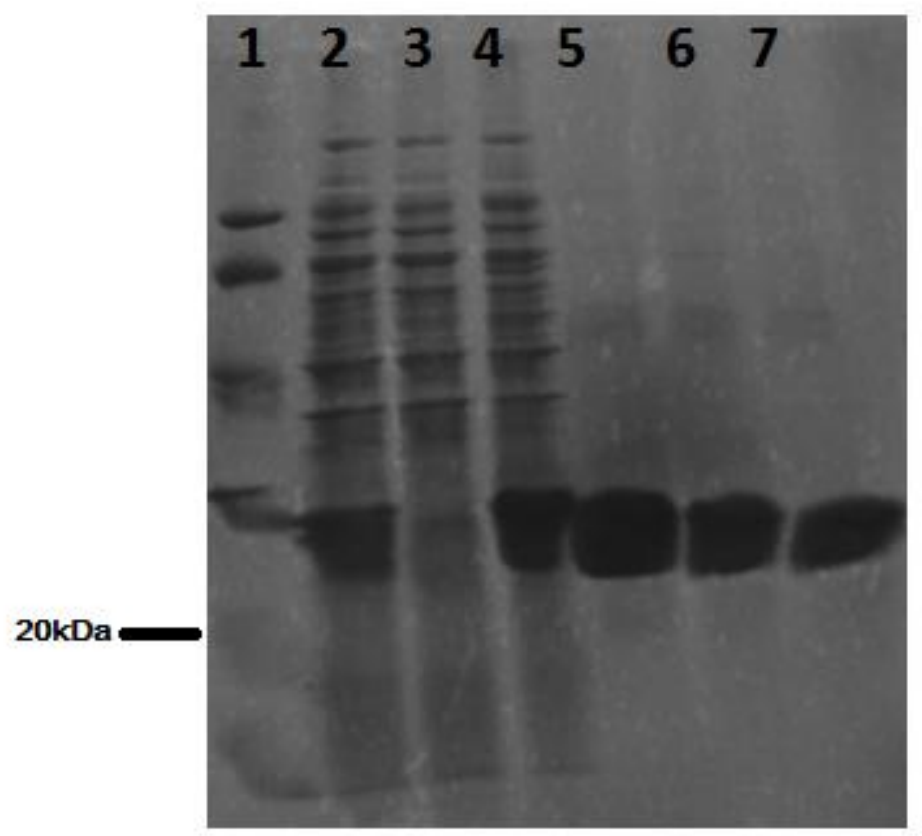

Figura 22. Gel SDS-PAGE 15\% de proteínas TCTP, em meio aquoso, após purificação em coluna de níquel. 1- Ladder LMW (Amersham). 2- Amostra pré-purificação. 3- Flowthrough da purificação. 4Primeira lavagem da purificação. 5- Segunda lavagem da purificação. 6- Primeira eluição da purificação, com 250mM de imidazol. 7- Segunda eluição da purificação, com 250mM de imidazol.

\subsection{Western Blotting e ELISA}

O western Blot utilizando anticorpos contra a cauda de histidina da proteína (Figura 23) confirmam que a banda intensa observada um pouco acima de $20 \mathrm{kDa}$ é a TCTP. 


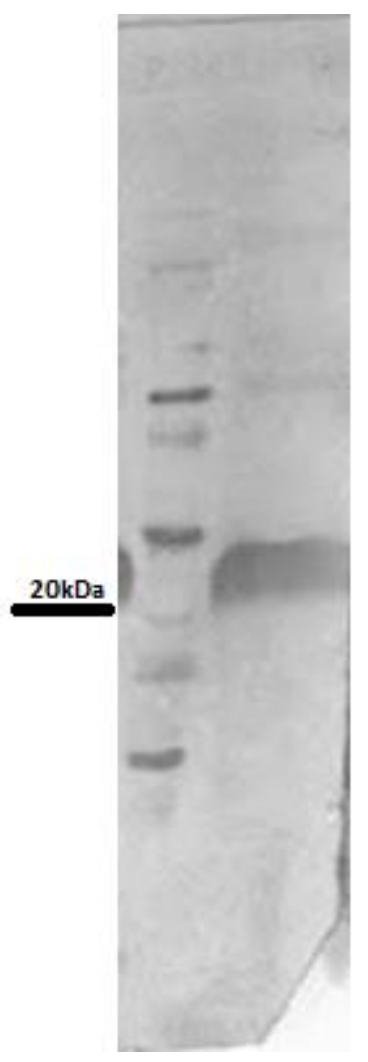

Figura 23. Western Blot da proteína purificada com anticorpo primário Anti-His. 1- Ladder Novex Sharp Pre-Stained (Thermo Fisher Scientific). 2- Amostra purificada.

Quando essa proteína purificada foi utilizada como alvo contra soros de camundongos infectados, houve o reconhecimento da mesma. No entanto, isso também aconteceu com o soro de camundongos não infectados (Figura 24). Isso significa que os camundongos sem a infecção de Paracoccidioides estão gerando anticorpos capazes de reconhecer a proteína. Esse reconhecimento pode ser devido à apresentação de outros patógenos aos animais, os quais elicitaram a produção de anticorpos que reconhecem a proteína ou a anotação errônea, por parte dos pesquisadores que manipularam os animais, o grupo controle como tal, em vez de grupo teste. 


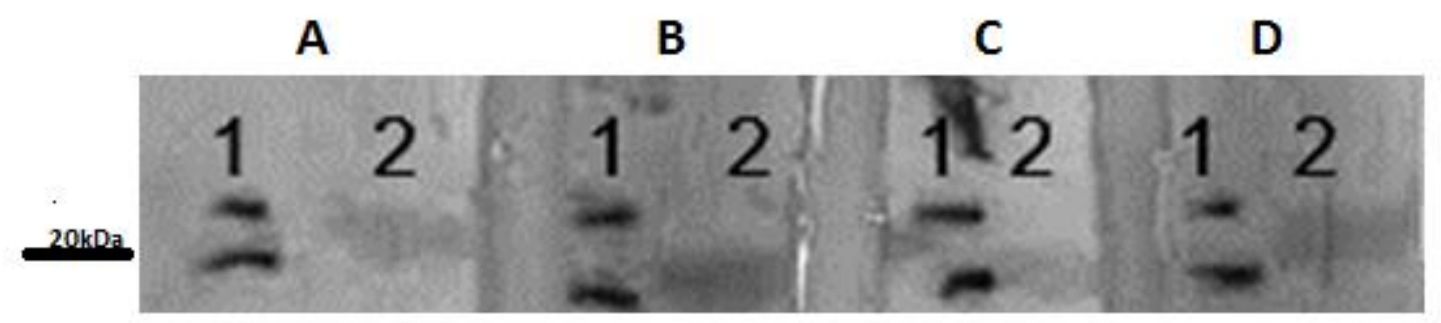

Figura 24.Western blot de detecção de proteínas heterólogas de E.coli contra soros de camundongos infectados por Pb18. 1- Ladder Novex Sharp Pre-Stained (Thermo Fisher Scientific). 2- amostra de proteína purificada de E.coli. A: Controle Negativo.B: Soro positivo 1. C: Soro positivo 2. D: Soro positivo 3.

Para se avaliar se a conformação proteica pudesse interferir no reconhecimento por anticorpos dos camundongos infectados, foram feitos ensaios de ELISA em duplicata para cada amostra. Dentre os resultados observados (Figura 25) aparece apenas o resultado de anticorpo primário diluído 1:1.000, a proteína foi reconhecida de forma similar pelos soros de camundongos infectados e de camundongos não infectados, com a exceção de uma amostra oriunda de camundongo infectado, a qual gera um sinal estatisticamente diferente dos demais $(p<0,01$ em ANOVA one-way seguido de pós-teste de Bonferroni).

\section{ELISA 1:1000}

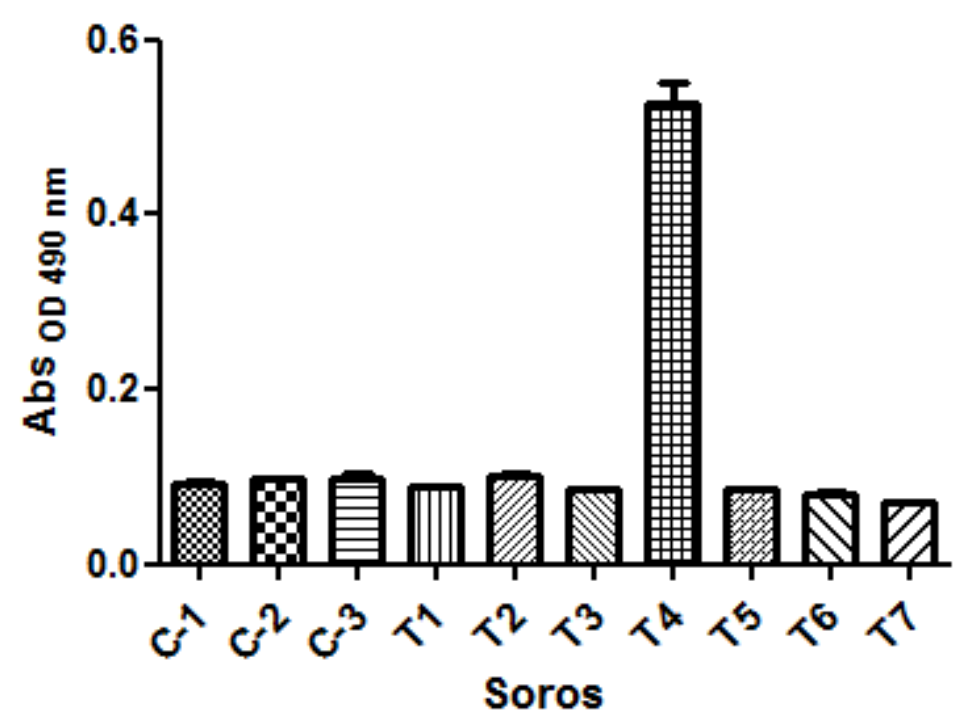

Figura 25. Absorbância sinal gerada a partir do teste ELISA, com anticorpo primário diluído 1:1000, onde C- representa uma amostra de controle negativo e amostras $\mathrm{T}$ representam amostras de camundongos infectados. 
Os resultados gerados a partir dos testes de Western Blot e de ELISA indicam que, ao menos sob as condições testadas, a proteína TCTP de Paracoccidioides spp. não é viável como um antígeno para ensaios de imunodiagnóstico para a detecção da Paracoccidioidomicose. O reconhecimento feito mesmo pelas amostras de soros nãoinfectados pode ser justificada pela alta semelhança de estrutura primária desta proteína dentre os eucariotos (HINOJOSA-MOYA et al., 2008), o que poderia gerar uma reação cruzada com diversos outros organismos que venham a entrar em contato com os camundongos. Também existe a possibilidade de erros manuseio das amostras infectadas e não-infectadas, de forma que os grupos denotados como tal não sejam representativos, o que faz necessário a repetição desses testes com mais soros de animais, provenientes de outros grupos de pesquisa.Dentre as alternativas que podem ser exploradas futuramente para o diagnóstico da PCM estão o uso de outras proteínas como antígeno, como a proteína Y20, que é expressa significativamente pela levedura de P.brasiliensis(DAHER et al., 2005), além de ser $92 \%$ idêntica com seu homólogo em P.lutzii. Uma outra possibilidade é usar um peptídeo derivado da TCTP nestes ensaios, composto pelos resíduos 57 a 64 da proteína, pois essa região é razoavelmente diferente das equivalentes em outros fungos e em H.sapiens e M.musculus, além de estar predita como um possível antígeno para células B pelo programa Bepipred, como discutido na sessão de predições in silico.

\subsection{Transfecção de L.tarentolae}

Concomitantemente aos ensaios de imunodiagnóstico, foram feitos a transfecção de L.tarentolae com pLEXSY/TCTP e a confirmação desse inserto na cultura por PCR. Embora a confirmação do inserto tenha sido bem-sucedida (Figura 26), o resultado dos ensaios de imunodiagnóstico foi negativo. Assim, foi decidido que esses ensaios não seriam testados com a proteína oriunda de L.tarentolae, uma vez que as alterações pós-traducionais desse organismo são bastante similares com a de H.sapiens e provavelmente não aumentariam o reconhecimento da proteína pelo soro de animais infectados. Além disso, os resultados das predições in silico apontam que é improvável a presença de $\mathrm{N}$-glisosilações. Portanto, foram analisados componentes relacionadas à possível função de chaperona da proteína, cujos resultados são descritos a seguir. 


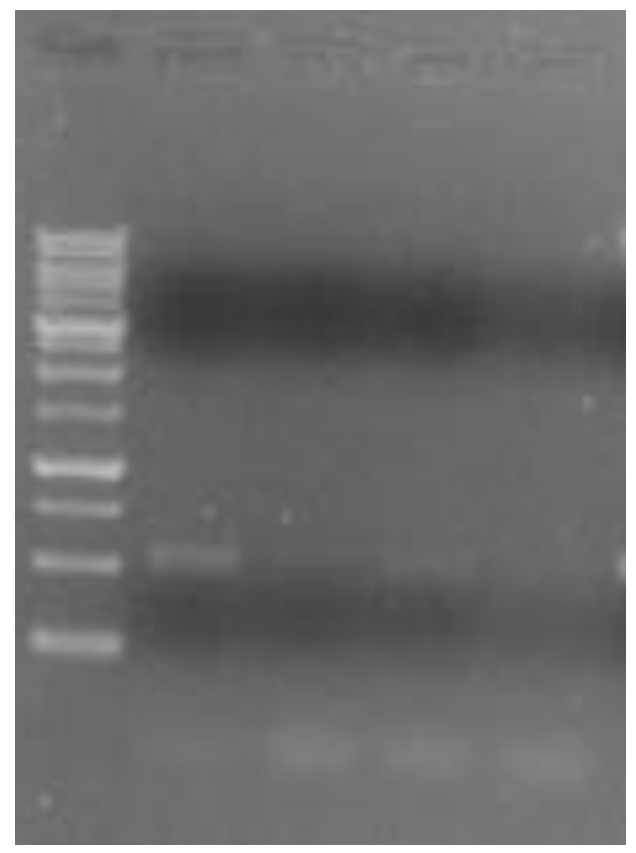

Figura 26. Eletroforese em gel de agarose a $1 \%$ da PCR do gene TCTP a partir de DNA isolado de L.tarentolae. 1- Ladder $1 \mathrm{~kb}$ (Kasvi). 2- Controle positivo (cDNA de micélio de Paracoccidioides brasiliensis). 3-negativo. 4-DNA total de L. tarentolae transfectada com pLEXSY/TCTP. 5-DNA total de L.tarentolae transfectada com pLEXSY/vazio.

\subsection{Análises de estruturas secundárias e estabilidade estrutural por Dicroísmo Circular}

A estrutura secundária e a estabilidade da proteína chaperona foram avaliadas por dicroísmo circular na região distante do ultravioleta (260-190 nm) no pH 7,0 e faixa de temperatura de $25^{\circ} \mathrm{C}$ a $95^{\circ} \mathrm{C}$. O perfil da estrutura secundária da proteína foi calculado a partir de espectros gerados em $25^{\circ} \mathrm{C}$. Os valores calculados para a estrutura da proteína mostraram que a estrutura da proteína é centrada em hélice- $\alpha$ apresentando porcentagem de $37 \%$, seguida por estrutura de folhas betas, com $32 \%$ (Figura 27).

O ensaio de desnaturação e os espectros dicroicos obtidos nas faixas de temperatura de $25^{\circ} \mathrm{C}$ a $95^{\circ} \mathrm{C}$ apresentaram leve diminuição do sinal na região de $208 \mathrm{~nm}$, que é um dos sinais correspondentes a estrutura dehélice- $\alpha$ nas proteínas (Figura 28). A proteína não 
apresentou temperatura de transição entre conformação nativa para desnaturada, o que sugere a alta estabilidade estrutural desta chaperona (Figura 29).

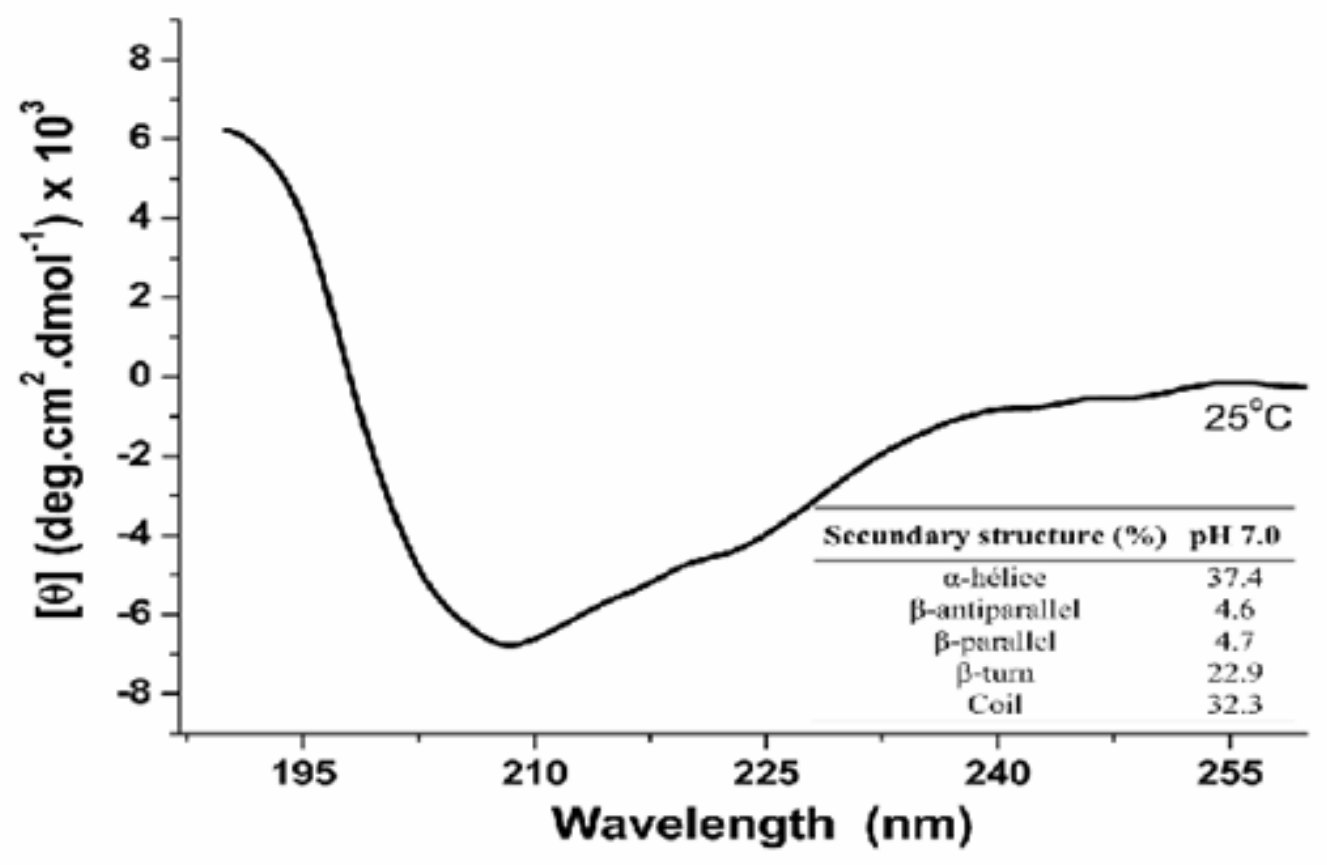

Figura 27. Espectro da estrutura secundaria da chaperona na região distante da UV $(260-190 \mathrm{~nm})$ em tampão Tris $\mathrm{HCl} \mathrm{pH} \mathrm{7,0}(2 \mathrm{mM})$ na temperatura de $25^{\circ} \mathrm{C}$. A tabela inserida corresponde ao conteúdo de estrutura secundária calculado para a proteína sob as condições descritas.

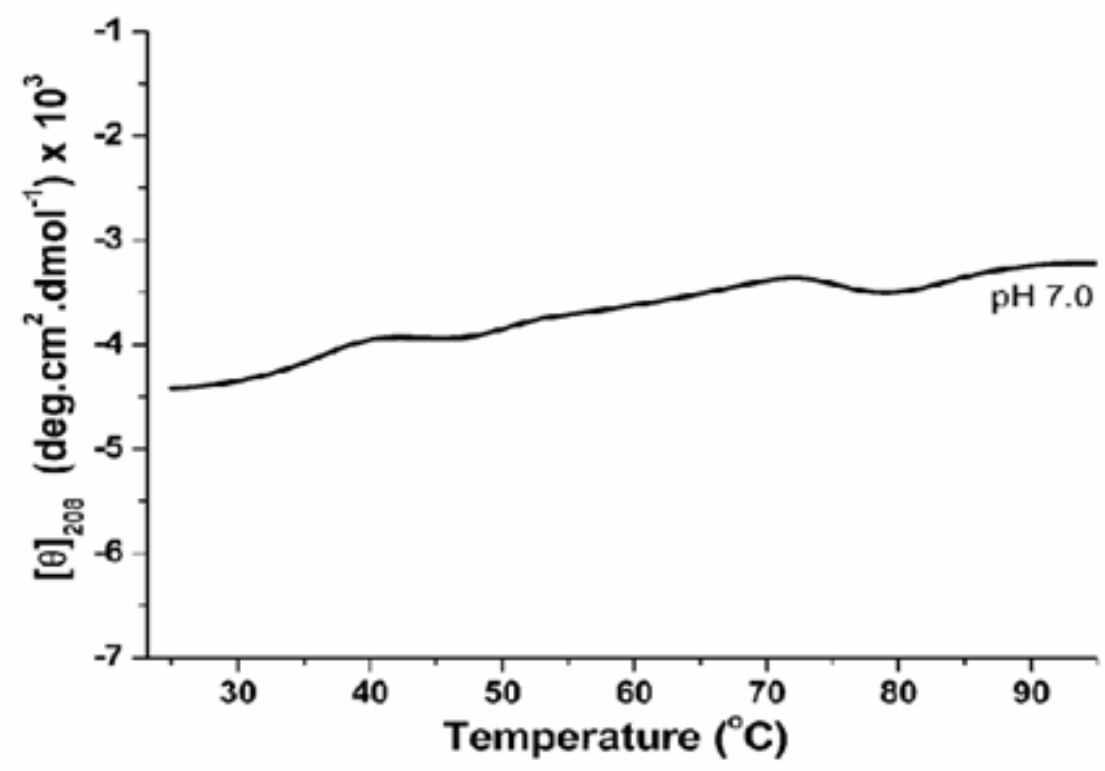

Figura 28. Curva de desnaturação térmica, em tampão Tris $\mathrm{HCl}$ pH 7,0 (2 mM), da chaperona monitorada em $208 \mathrm{~nm}$ apresentando estabilidade com aumento da temperatura. 


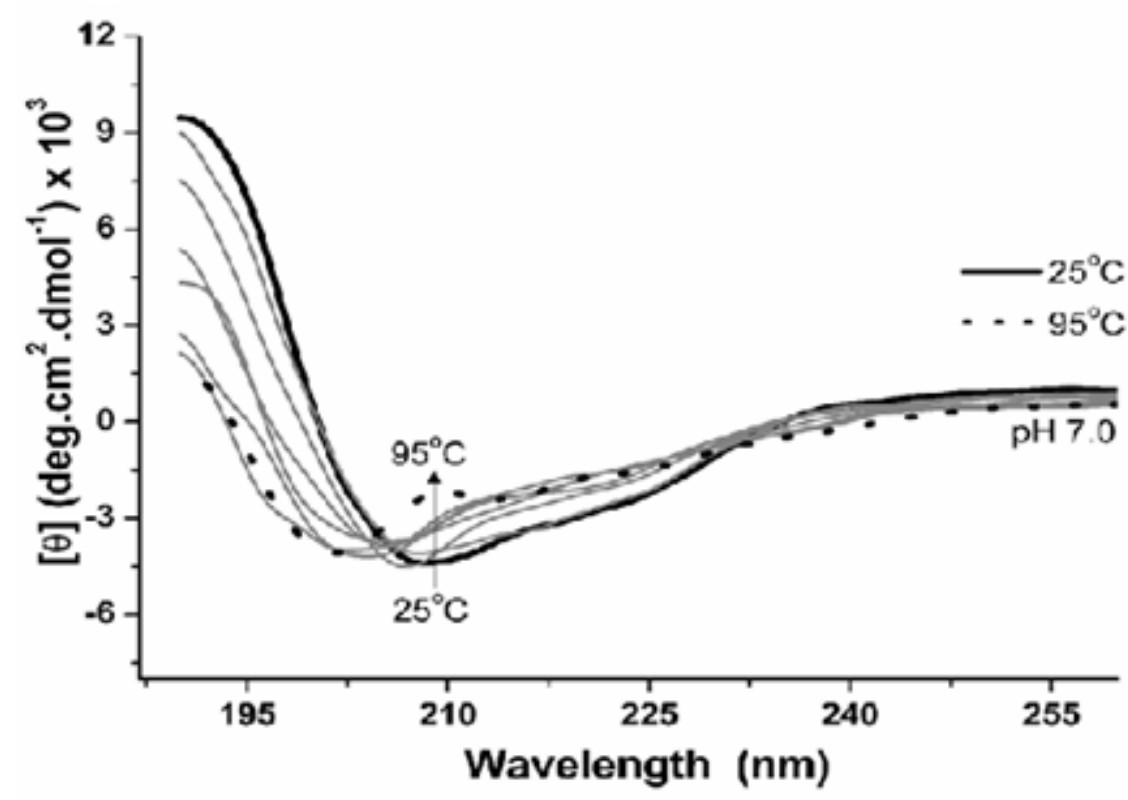

Figura 29. Espectros da curva de desnaturação térmica da chaperona $\left(25-95^{\circ} \mathrm{C}\right)$ em região distante do UV (260-190 nm), em tampão Tris HCl pH 7,0 (2 mM). A seta indica leve diminuição do sinal dicroico da proteína em $208 \mathrm{~nm}$ em função do aumento da temperatura.

O perfil da estrutura secundária da proteína em estudo foi calculado a partir de espectros gerados em $25^{\circ} \mathrm{C}$ (Figura 27). Os resultados mostraram que a estrutura é centrada em hélices-a, com percentual predominante de $37 \%$, seguida por folhas betas, com percentual de $32 \%$. De acordo com a literatura, hélices- $\alpha$ em maior percentual é característica das TCTPs, como observado na estrutura secundária de TCTP de Plasmodium knowlesi (pdb 1TXJ) com 35\% de hélices- $\alpha$ e $24 \%$ de folhas betas; TCTP de $H$. sapiens (pdb 1YZ1), 32\% de hélices- $\alpha$ e $25 \%$ de folhas betas. Essas proteínas, as quais são secretadas pelos organismos, apresentam em sua estrutura secundária percentual de hélices- $\alpha$ semelhante ao calculado para a proteína descrita neste trabalho, o que corrobora as análises de estrutura primária, onde a mesma foi classificada como uma TCTP. Em contraste com as proteínas citadas acima, a proteína TCTP de Schizosaccharomyces pombe(pdb IH6Q,(THAW et al., 2001)) que é um fungo, mas cuja proteína é localizada no citosol, possui $25 \%$ de sua estrutura em hélices- $\alpha$ e $24 \%$ em folhas-beta, o que pode indicar que a localização dessa proteína e as funções dela podem ser mais determinantes para o arranjo de estruturas secundárias do que relações filogenéticas. A análise da estrutura secundária de TCTP sob aumento de temperatura mostrou que houve leve mudança conformacional na estrutura da proteína, (Figura 28), houve diminuição do sinal dicroico na região de $208 \mathrm{~nm}$, sendo esta uma região 
que configura estrutura de hélice-a.,entretanto, esta mudança (Figura 29), não acarretou na desnaturação da proteína. Desta forma, sugere-se que a proteína em estudo é termoestável.

\subsection{Ensaios de Chaperona}

Foi verificado que a presença da proteína TCTP não foi capaz de impedir a perda de função da EcoRl após estresse térmico (Figura 30). Esse fenômeno, no entanto, é compatível com o efeito de chaperonas de baixo peso molecular. Isso porque essas chaperonas interagem com porções hidrofóbicas expostas de proteínas-alvo, formando complexos solúveis em meio intracelular. Essa interação, por ser mediada fundamentalmente por regiões hidrofóbicas, é inespecífica em relação às proteínas-cliente, variando assim o número de chaperonas necessárias para estabilizar proteínas cliente de diferentes massas. Esses complexos, apesar de serem solúveis, não costumam manter a proteína-alvo em sua conformação enzimaticamente ativa (HASLBECK et al., 2005; HUMPHREYS et al., 1999).

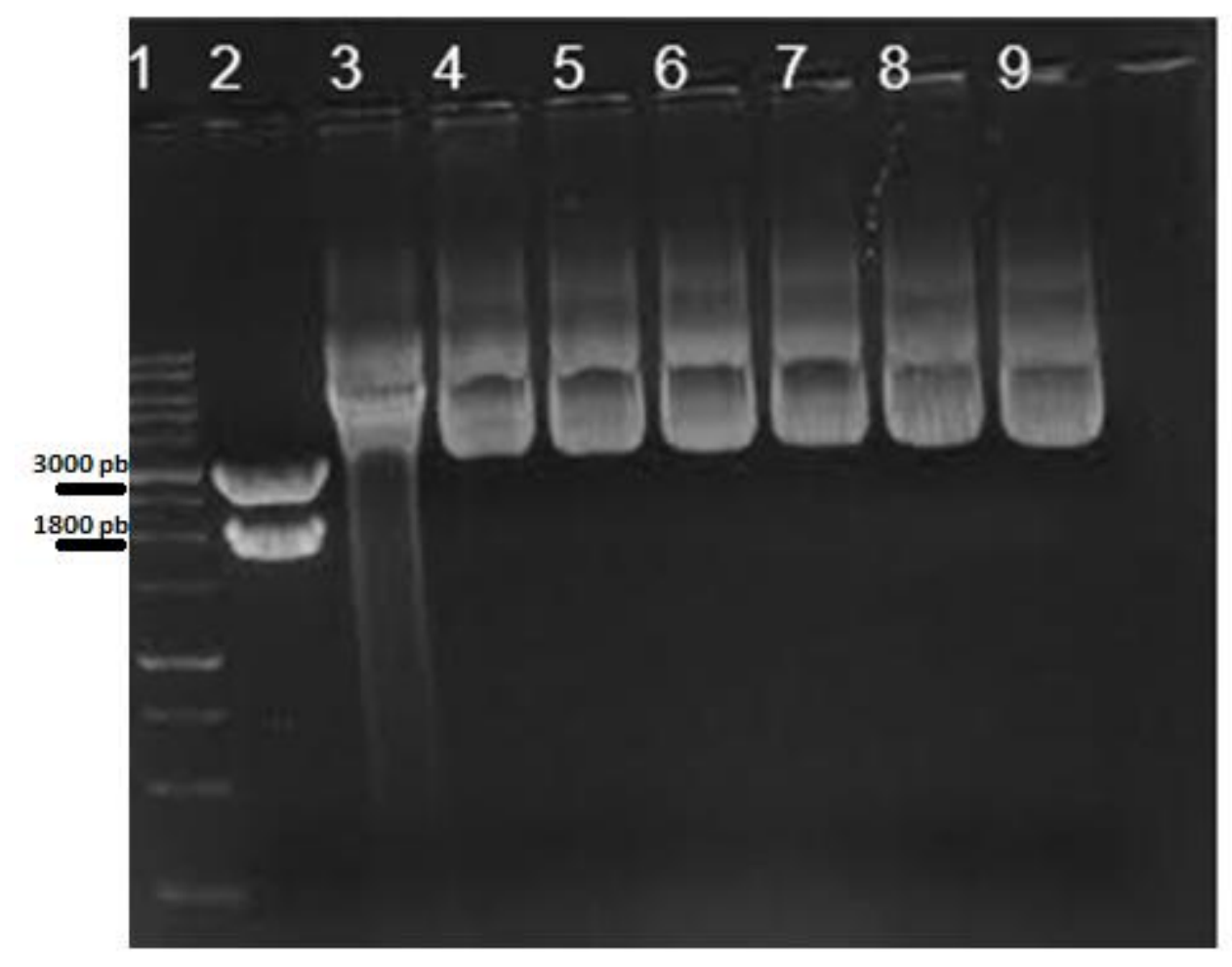

Figura 30. Teste de chaperona utilizando EcoRI e pGEM-tEASY incubados após $20^{\prime}$ a $65^{\circ} \mathrm{C}$ e depois a 2horas a $37^{\circ} \mathrm{C}$. 1- Ladder $1 \mathrm{~Kb}$ (Kasvi), 2- Amostra com $1 \mu \mathrm{gg}$ de TCTP sem incubação a 65. 3- Amostra com $10 \mu \mathrm{g}$ de TCTP. 4- Amostra com $1 \mu \mathrm{g}$ de TCTP. 5- Amostra com 0,1 $\mu \mathrm{g}$ de TCTP.6- Amostra com $0,01 \mu \mathrm{g}$ de TCTP. 7-Amostra com $1 \mathrm{ng}$ de TCTP. 8- Amostra com 0,1ng de TCTP. 9- Amostra com $0,01 \mathrm{ng}$ de TCTP. 
Nos ensaios envolvendo agregação de BSA, foi determinado que a concentração de $5 \mathrm{mg} / \mathrm{mL}$ resultou numa curva de absorção alta, em unidades arbitrárias, mas sem saturação, sendo assim utilizada para o ensaio com TCTP (Figura 31). Quando essa concentração de BSA foi incubada com TCTP, não se observou diferença significativa nas curvas de agregação, independente da concentração de TCTP (Figura 32). Uma possível explicação para isso é que pontes dissulfeto sejam importantes para a conformação da TCTP, assim a própria TCTP perderia sua função de chaperona em condições redutoras. A proteína TCTP em humanos, por exemplo, forma homodímeros, que são estabilizados por pontes dissulfeto(KIM et al., 2009). No entanto, a posição das cisteínas na proteína humana corresponde aos resíduos 28 e 172, sendo assim distantes entre si na estrutura primária, enquanto que os resíduos de cisteína na proteína fúngica são os de posição 31 e 33, o que poderia afetar a formação das pontes dissulfeto em primeiro lugar. Assim, futuramente, serão feitos ensaios de agregação de proteínas clientes submetidas a outros estresses, como o estresse térmico, na presença de TCTP. O mesmo tipo de ensaio também pode ser feito para outras proteínas-cliente, como lisozima, para avaliar a formação de agregados.

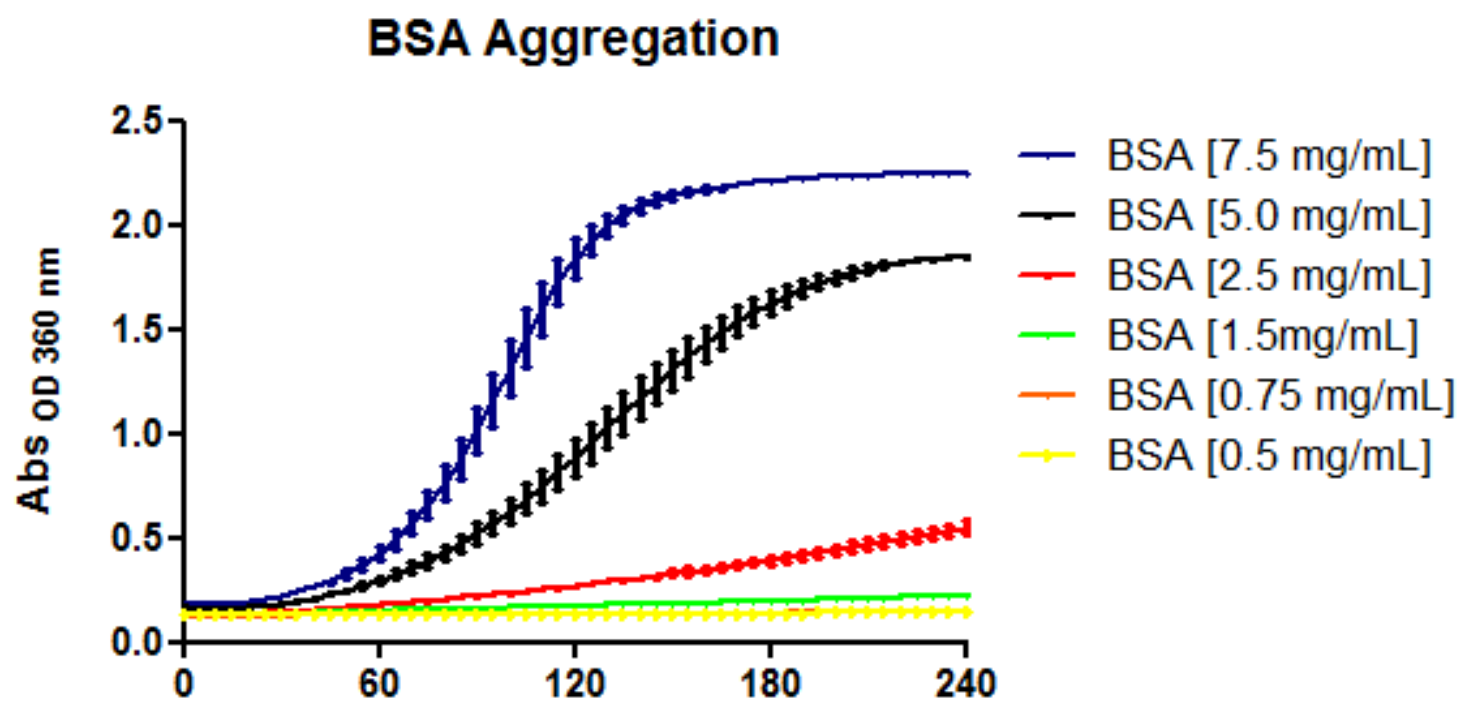

Minutes

Figura 31. Curva de cinética de absorbância a 360nm de diferentes concentrações de BSA em tampão PBS pH 7,4 e 20mM de DTT. 


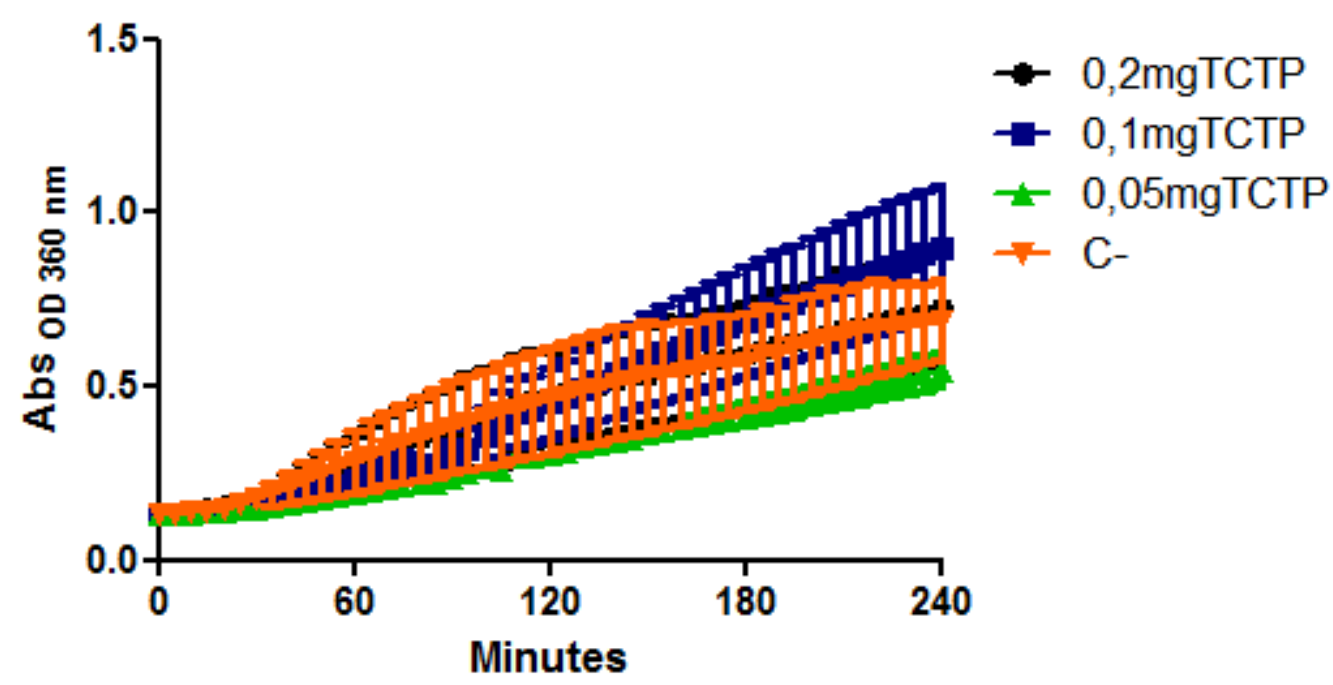

Figura 32. Curva de cinética de absorbância a $360 \mathrm{~nm}$ de BSA em $5 \mathrm{mg} / \mathrm{mL}$ e diferentes quantidades de TCTP em tampão PBS pH 7,4 e 20mM de DDT.

\subsection{Ensaio de Termotolerância em E.coli}

O efeito de proteção in vivo da expressão da proteína TCTP frente a estresse térmico foi avaliado por meio do ensaio de termotolerância em E.coli. As contagens de UFCs ao longo do experimento indicam que, no tempo zero, havia aproximadamente dez vezes mais células viáveis na cultura controle do que na cultura teste. Já durante os períodos de quinze e trinta minutos,a cultura teste passa a apresentar mais células viáveis, chegando a aproximadamente sete vezes mais células do que a cultura teste no tempo de trinta minutos (Figura 33). A diferença observada entre as culturas no tempo zero pode ser justificada pela expressão da proteína na cultura teste, a qual pode levar a uma maior mortalidade de bactérias. 

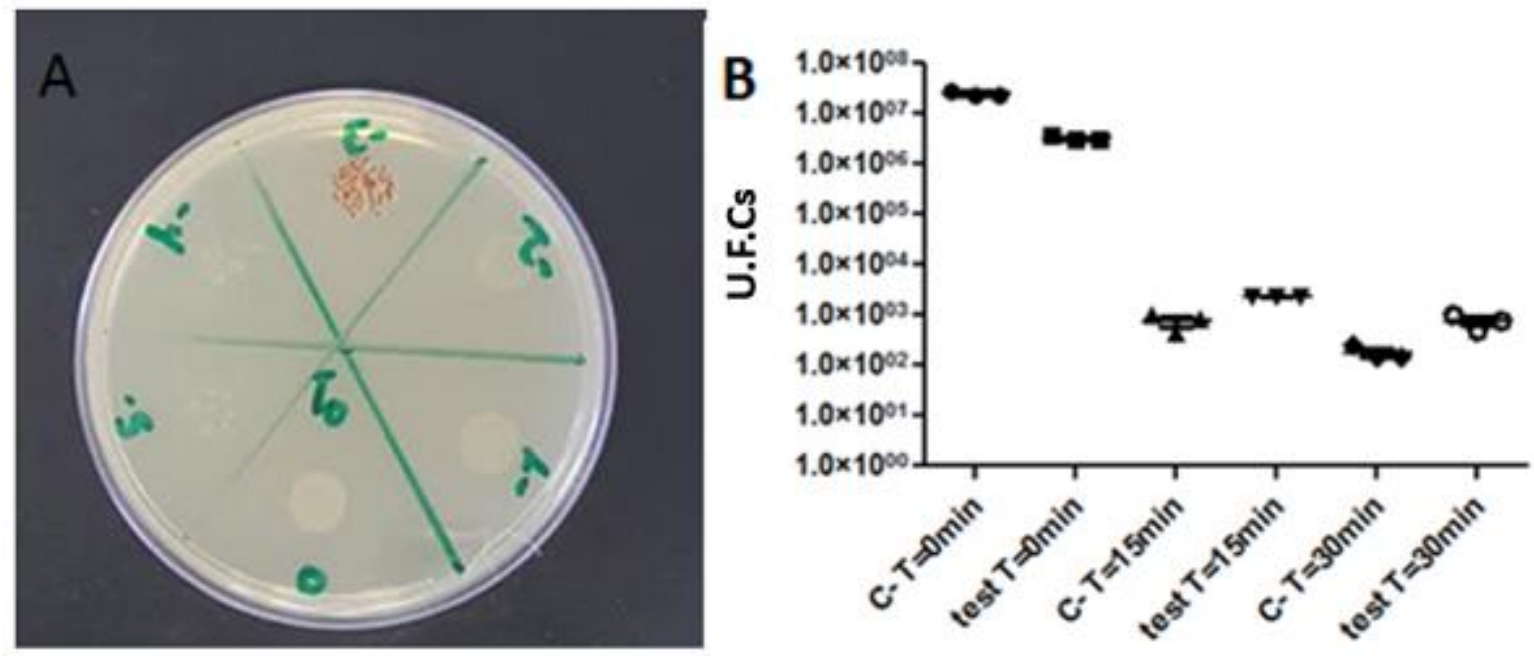

Figura 33. Ensaio de termotolerância em E.coli. Exemplo de plaqueamento pelo método de Miles-Misra, utilizado para a contagem de UFCs ao longo do experimento, a diluição pontilhada em vermelho foi utilizada para o cálculo de UFCs dessa placa (A). Scatter plot da contagem de UFCs ao longo do experimento em culturas teste e controle (B)

Embora o sistema de expressão heteróloga (células bacterianas)possua várias características celulares distintas do sistema de expressão original da proteína (células fúngicas), essa estratégia tem sido usada para avaliar o efeito protetor de proteínas oriundas de mamíferos (MUCHOWSKI; CLARK, 1998), invertebrados(EZEMADUKA et al., 2014; SEO et al., 2006) e plantas (SOTO et al., 1999) frente a estresse térmico, sendo assim uma estratégia adaptável para proteínas de diversos sistemas. Para se avaliar o efeito de proteção em células eucarióticas, mais parecidas com o sistema homólogo, poderia se empregar células eucarióticas de expressão heteróloga e submetê-las ao ensaio de termotolerância, adaptando a temperatura de estresse (ANGELIDISet al., 1991) ou ainda transfectar células com o gene da chaperona, as quais expressam uma proteína-cliente, como luciferase, e acompanhar a fluorescência resultante ao longo de um período de estresse térmico (FORREITERet al., 1997). A análise utilizando células eucarióticas pode ser útil futuramente, uma vez que a TCTP foi descrita como uma proteína associada a grânulos de estresse e ao proteassoma após estresse térmico, em Saccharomyces cerevisiae(RINNERTHALER et al., 2013). A temperatura utilizada foi de $50^{\circ} \mathrm{C}$ pois essa temperatura causa a lise de células de E.coli(MUCHOWSKI; CLARK, 1998; SOTO et al., 1999; SURAGANI et al., 2013), o que permite uma observação mais direta da proteção causada pela expressão heteróloga do que caso o ensaio fosse feito a temperaturas de estresse que ainda permitissem o crescimento bacteriano, uma vez que uma eventual diferença nas UFCs entre os grupos teste e controle poderia também ser justificada por uma capacidade maior de divisão celular causada pela proteína heteróloga. O método de Miles-Misra (MILESet al., 1938) foi utilizado para o 
plaqueamento, uma vez que em vários trabalhos da literatura (MUCHOWSKI; CLARK, 1998; SEO et al., 2006; SOTO et al., 1999; SURAGANI et al., 2013), a diluição seriada não é descrita em detalhes, esse método permite o plaqueamento de várias diluições simultaneamente e o efeito de proteção de diferentes chaperonas pode mudar a diluição ótima para diferentes culturas. O uso de canamicina, em vez de ampicilina como foi feito em outros trabalhos(SEO et al., 2006; SOTO et al., 1999), pode diminuir o erro de contagem de colônias, porque o gene de resistência a ampicilina em plasmídeos codifica uma beta-lactamase, que é secretada pela bactéria. Assim, após períodos longos de crescimento bacteriano, a ampicilina ao redor das colônias é degradada, gerando zonas sem ampicilina nas placas, permitindo o crescimento de bactérias sem plasmídeo, as quais não estão necessariamente associadas às bactérias do ensaio. Já no plasmídeo pET28a, o gene de resistência a canamicina codifica uma enzima que permanece no citosol das bactérias, portanto evitando a complicação das zonas sem antibiótico. Finalmente, o presente ensaio representa um avanço no entendimento da função de chaperona da TCTP in vivo, uma vez que o trabalho original que descreveu a proteína como possuidora dessa função fez um ensaio qualitativo, onde foi observado apenas a presença de crescimento de culturas expressando a proteína em comparação com culturas controle (GNANASEKARet al., 2010).

\section{Conclusões}

A proteína TCTP de Paracoccidioides possui atributos preditos in silico interessantes para sua utilização no imunodiagnóstico, embora possua estrutura primária bem conservada entre eucariotos e, em particular, fungos.

A expressão heteróloga em E.coli foi bem-sucedida, com quantidades significativas e com boa pureza da proteína, com poucos passos restantes para otimização de sua purificação. A expressão em L.tarentolae não foi finalizada, em razão dos resultados de predição de $\mathrm{N}$-glicosilações e dos resultados de imunodiagnóstico.

Os testes de imunodiagnóstico apresentaram resultados negativos para o uso da TCTP de Paracoccidioides como alvo de diagnóstico. Esses resultados podem ser relativos à produção de anticorpos nos animais infectados ou a erros no manuseio das amostras anotadas como teste e controle, durante a coleta. Assim, são necessários mais estudos, com um número maior de soros, provenientes de um outro grupo de pesquisa, para uma melhor avaliação do potencial de imunodiagnóstico da proteína.

A proteína TCTP de Paracoccidioides possui propriedades compatíveis com a de uma chaperona responsiva a choque térmico, como termoestabilidade e capacidade de aumentar 
a sobrevivência de culturas de E.coli expostas a choque-térmico. As propriedades de chaperona propriamente ditas, até o presente momento, não foram elucidadas.

\section{Perspectivas}

Em relação aos testes diagnósticos, já que não foi possível determinar no presente trabalho a aplicabilidade da TCTP como um antígeno em ensaios de imunodiagnóstico, essa possibilidade permanece testável. Além desta aplicação, a proteína TCTP de Paracoccidioidesspp. possui algumas propriedades que a tornam interessantes para a aplicação em composições vacinais, uma vez que a proteína é secretada pela levedura de P.lutzii (WEBER et al., 2012) e possui estrutura primária idêntica entre as espécies do gênero. Além desses fatores, alguns trabalhos na literatura indicam que a TCTP de Homo sapiens possui um domínio em N-terminal, chamado de "domínio de transdução proteica", que permite a proteína ser internalizada por diferentes células, o que permite aplicações em delivery de moléculas (KIM et al., 2011) e em composições vacinais de entrega via nasal (BAE et al., 2016). Essa última é interessante por propiciar respostas imunes no próprio epitélio respiratório, via $\lg A$, além da resposta de $\lg G$ no sangue, o que significa uma resposta imune mais intensa no local primário de infecção do fungo. Assim, mesmo que em ensaios futuros verifique-se baixa imunogenicidade da TCTP, essa poderia ser usada como carreadora de outras proteínas mais imunogênicas, como a gp43(BRAGA et al., 2009).

Já em relação às propriedades de chaperona da TCTP, tanto em formas secretadas quanto citosólicas, ainda restam vários aspectos a serem analisados. Quanto à termoestabilidade da proteína, vista de forma inédita no presente trabalho, resta saber quais características da proteína conferem essa termoestabilidade. Caso sejam interações eletroestáticas entre resíduos dela, por exemplo, ensaios de dicroísmo circular da proteína na presença de sais poderiam ser usados (MOTTA et al., 2012). Também não se sabe como a TCTP interage com proteínas-cliente para evitar a agregação dessas. Caso essa interação seja similar a de outras chaperonas de baixo peso molecular, como as sHSPs (HASLBECK et al., 2005) e outras (HUMPHREYS et al., 1999; SURAGANI et al., 2013), ela se dá por meio de regiões hidrofóbicas expostas, que interagem com regiões expostas das proteínas-cliente e as estabilizam, de forma a evitar a formação de agregados. Essa hipótese pode ser testada por meio de modelagens por homologia e mutagênese das sequências preditas pela modelagem para testes in vitro(SURAGANI et al., 2013) ou ensaios envolvendo bis-ANS (4,4'bis(1-anilinonaphthalene 8-sulfonate))(DAS; SUREWICZ, 1995; LEE et al., 1997). Várias sHSPs formam estruturas oligoméricas, que afetam a capacidade de chaperona dessas 
(HASLBECK et al., 2005) e as TCTPs secretadas de H. sapiens(KIM et al., 2009)formam homodímeros. É possível que essa dimerização afete a função da chaperona, como ocorre com Hsp26 de S.cerevisiae(HASLBECK et al., 1999; VERGHESE et al., 2012). As sHSPs também atuam em sinergia com outras chaperonas para exercer sua atividade (HASLBECK et al., 2005), portanto a TCTP também poderia ter interactantes sinergísticos para sua função de chaperona? Em S. cerevisiae, a TCTP interage com proteínas do proteassoma e grânulos de estresse após estresse térmico (RINNERTHALER et al., 2013), existe alguma relação da função chaperona da TCTP com essas interações? Uma vez levantadas essas hipóteses, ensaios de interação proteína-proteína podem oferecer algumas respostas.

\section{Referências bibliográficas}

ALBUQUERQUE, C. F.; MARQUES SILVA, S. H.; CAMARGO, Z. P. Improvement of the Specificity of an enzyme-linked immunosorbent assay for diagnosis of paracoccidioidomycosis. Journal of clinical microbiology, v. 43, n. 4, p. 1944-1946, 2005.

ANFINSEN, C. B. et al. The kinetics of formation of native ribonuclease during oxidation of the reduced polypeptide chain. Proceedings of the National Academy of Sciences of the United States of America, v. 47, n. 9, p. 1309-1314, 1961.

ANGELIDIS, C. E.; LAZARIDIS, I.; PAGOULATOS, G. N. Constitutive expression of heat-shock protein 70 in mammalian cells confers thermoresistance. European Journal of Biochemistry, v. 199, n. 1, p. 3539, 1991.

BAE, H. D. et al. Potential of translationally controlled tumor protein-derived protein transduction domains as antigen carriers for nasal vaccine delivery. Molecular Pharmaceutics, v. 13, n. 9, p. 31963205, 2016.

BEITZ, E. TEXshade: shading and labeling of multiple sequence alignments using LATEX2 epsilon. Bioinformatics (Oxford, England), v. 16, n. 2, p. 135-139, 2000.

BLOM, N., GAMMELTOFT, S., AND BRUNAK, S. Sequence- and structure-based prediction of eukaryotic protein phosphorylation sites. Journal of Molecular Biology, v. 294, n. 5, p. 1351-1362, 1999.

BLOM N, SICHERITZ-PONTEN T, GUPTA R, GAMMELTOFT S, B. S. Prediction of post-translational glycosylation and phosphorylation of proteins from the amino acid sequence. Proteomics, v. 4, n. 6, p. 1633-1649, 2004.

BÖHM, G.; MUHR, R.; JAENICKE, R. Quantitative analysis of protein far UV circular dichroism spectra. Protein engineering, v. 5, n. 3, p. 191-195, 1992.

BOMMER, U. A.; THIELE, B. J. The translationally controlled tumour protein (TCTP). International Journal of Biochemistry and Cell Biology, v. 36, n. 3, p. 379-385, 2004.

BORGES, C. L. et al. The antigenic and catalytically active formamidase of Paracoccidioides 
brasiliensis: protein characterization, cDNA and gene cloning, heterologous expression and functional analysis of the recombinant protein. Microbes and infection / Institut Pasteur, v. 7, n. 1, p. 66-77, 2005.

BRAGA, C. J. M. et al. Paracoccidioides brasiliensis vaccine formulations based on the gp43-derived P10 sequence and the Salmonella enterica FliC flagellin. Infection and Immunity, v. 77, n. 4, p. 17001707, 2009.

CAMARGO, Z. P.; UNTERKIRCHER, C.; TRAVASSOS, L. R. Identification of antigenic polypeptides of Paracoccidioides brasiliensis by immunoblotting. Journal of Medical and Veterinary Mycology, v. 27, p. 407-412, 1989.

CASADEVALL, A. Fungal virulence, vertebrate endothermy, and dinosaur extinction: Is there a connection? Fungal Genetics and Biology, v. 42, n. 2, p. 98-106, 2005.

CASADEVALL, A. Fungi and the Rise of Mammals. PLoS Pathogens, v. 8, n. 8, 2012.

CISALPINO, P. S. et al. Cloning, characterization, and epitope expression of the major diagnostic antigen of Paracoccidioides brasiliensis. Journal of Biological Chemistry, v. 271, n. 8, p. 4553-4560, 1996.

COUTINHO ZF, WANKE B, TRAVASSOS C, OLIVEIRA RM, XAVIER DR, C. C. J. Hospital morbidity due to paracoccidioidomycosis in Brazil (1998-2006). Tropical Medicine and International Health, v. 20, n. 5, p. 673-680, 2015.

CUNHA, D. A et al. Heterologous Expression, Puri cation, and Immunological Reactivity of a Recombinant HSP60 from. Clinical and Diagnostic Laboratory Immunology, v. 9, n. 2, p. 374-377, 2002.

DA SILVA, J. DE F. et al. Advances and challenges in paracoccidioidomycosis serology caused by Paracoccidioides species complex: An update. Diagnostic Microbiology and Infectious Disease, v. 84, n. 1, p. 87-94, 2016.

DA SILVA, S. P. et al. Differential expression of an hsp70 gene during transition from the mycelial to the infective yeast form of the human pathogenic fungus Paracoccidioides brasiliensis. Molecular Microbiology, v. 31, n. 4, p. 1039-1050, 1999.

DAHER, B. S. et al. The highly expressed yeast gene pby20 from Paracoccidioides brasiliensis encodes a flavodoxin-like protein. Fungal Genetics and Biology, v. 42, n. 5, p. 434-443, 2005.

DAS, K. P.; SUREWICZ, W. K. Temperature-induced exposure of hydrophobic surfaces and its effect on the chaperone activity of alpha-crystallin. FEBS letters, v. 369, n. 2-3, p. 321-325, 1995.

EZEMADUKA, A. N. et al. A small heat shock protein enables Escherichia coli to grow at a lethal temperature of 50 degrees $C$ conceivably by maintaining cell envelope integrity. Journal of Bacteriology, v. 196, n. 11, p. 2004-2011, 2014.

FELIPE, M. S. S. et al. Transcriptional profiles of the human pathogenic fungus Paracoccidioides brasiliensis in mycelium and yeast cells. Journal of Biological Chemistry, v. 280, n. 26, p. 2470624714, 2005.

FERNANDES, V. C. et al. Combined use of Paracoccidioides brasiliensis recombinant rPb27 and rPb40 antigens in an enzyme-linked immunosorbent assay for immunodiagnosis of paracoccidioidomycosis. 
Journal of Immunological Methods, v. 367, n. 1-2, p. 78-84, 2011.

FORREITER, C.; KIRSCHNER, M.; NOVER, L. Stable transformation of an Arabidopsis cell suspension culture with firefly luciferase providing a cellular system for analysis of chaperone activity in vivo. The Plant cell, v. 9, n. 12, p. 2171-81, 1997.

FRISHMAN, D.; ARGOS, P. Knowledge-based protein secondary structure assignment. Proteins, p. 566-579, 1995.

GARGAS, A. et al. Geomyces destructans sp. nov. associated with bat white-nose syndrome. Mycotaxon, v. 108, n. June, p. 147-154, 2009.

GASTEIGER, E. et al. Protein identification and analysis tools on the ExPASy server. In: WALKER, J. . (Ed.). . The Proteomics Protocols Handbook. [s.I.] Humana Press, 2005. p. 571-607.

GEGEMBAUER, G. et al. Serology of paracoccidioidomycosis due to Paracoccidioides lutzii. PLoS Neglected Tropical Diseases, v. 8, n. 7, p. e2986, 2014.

GNANASEKAR, M.; DAKSHINAMOORTHY, G.; RAMASWAMY, K. Translationally contrlolled tumor protein is a novel heat shock protein with chaperone-like activity. Biochem Biophys Res Commun, v. 386, n. 2, p. 333-337, 2010.

GONZALEZ, A.; HERNANDEZ, O. New insights into a complex fungal pathogen: the case of Paracoccidioides spp. Yeast (Chichester, England), v. 33, p. 113-128, 2016.

HASLBECK, M. et al. Hsp26: a temperature-regulated chaperone. The EMBO journal, v. 18, n. 23, p. 6744-51, 1999.

HASLBECK, M. et al. Some like it hot: the structure and function of small heat-shock proteins. Nature Structural \&\#38; Molecular Biology, v. 12, n. 10, p. 842-846, 2005.

HAWKSWORTH, D. L.; ROSSMAN, A. Y. Where are all the undescribed fungi? Phytopathology, v. 87, n. 9, p. 888-891, 1997.

HINOJOSA-MOYA, J. et al. Phylogenetic and structural analysis of translationally controlled tumor proteins. Journal of Molecular Evolution, v. 66, n. 5, p. 472-483, 2008.

HUMPHREYS, D. T. et al. Clusterin has chaperone-like activity similar to that of small heat shock proteins. Journal of Biological Chemistry, v. 274, n. 11, p. 6875-6881, 1999.

JEFFERIS, R. Posttranslational modifications and the immunogenicity of biotherapeutics. Journal of Immunology Research, v. 2016, 2016.

KARKOWSKA-KULETA, J.; KOZIK, A. Moonlighting proteins as virulence factors of pathogenic fungi, parasitic protozoa and multicellular parasites. Molecular Oral Microbiology, v. 29, n. 6, p. 270-283, 2014.

$\mathrm{KIM}, \mathrm{M}$. et al. Dimerization of translationally controlled tumor protein is essential for its cytokine-like activity. PLoS ONE, v. 4, n. 7, p. 1-14, 2009.

$\mathrm{KIM}, \mathrm{M}$. et al. A protein transduction domain located at the $\mathrm{NH}$-terminus of human translationally controlled tumor protein for delivery of active molecules to cells. Biomaterials, v. 32, n. 1, p. 222230, 2011. 
KIM, Y. E. et al. Molecular Chaperone Functions in Protein Folding and Proteostasis. [s.I: s.n.]. v. 82

KROGH A, LARSSON B, VON HEIJNE G, S. EL. Predicting transmembrane protein topology with a hidden Markov model: Application to complete genomes. Journal of Molecular Biology, v. 305, p. 567-580, 2001.

LARSEN, J. E. .; LUND, O.; NIELSEN, M. Improved method for predicting linear B-cell epitopes. Immunome Research, v. 2, n. 2, 2006.

LEE, G. J. et al. A small heat shock protein stably binds heat-denatured model substrates and can maintain a substrate in a folding-competent state. EMBO Journal, v. 16, n. 3, p. 659-671, 1997.

LEITÃO, N. P. et al. Paracoccidioides lutzii Plp43 Is an active glucanase with partial antigenic Identity with P. brasiliensis gp43. PLoS Neglected Tropical Diseases, v. 8, n. 8, p. 1-9, 2014.

MARQUES, A. Paracoccidioidomycosis: a century from the first case report. Anais Brasileiros de Dermatologia, v. 83, n. 3, 2008.

MEDINA-ACOSTA, E.; CROSS, G. A. . Rapid isolation of DNA from trypanosomatid protozoa using a simple "mini-prep" procedure. Molecular and Biochemical Parasitology, n. 59, p. 327-330, 1993.

MILES, A. A.; MISRA, S. S.; IRWIN, J. O. The estimation of the bactericidal power of the blood. The Journal of hygiene, v. 38, n. 6, p. 732-749, 1938.

MORAIS, E. A. et al. TLR 9 involvement in early protection induced by immunization with $\mathrm{rPb} 27$ against Paracoccidioidomycosis. Microbes and Infection, v. 18, n. 2, p. 137-147, 2016.

MOTTA, F. N. et al. The Trypanosoma cruzi virulence factor oligopeptidase B (OPBTc) assembles into an active and stable dimer. PLoS ONE, v. 7, n. 1, 2012.

MUCHOWSKI, P. J.; CLARK, J. I. ATP-enhanced molecular chaperone functions of the small heat shock protein human alphaB crystallin. Proceedings of the National Academy of Sciences of the United States of America, v. 95, n. 3, p. 1004-1009, 1998.

NAGANO-ITO, M.; ICHIKAWA, S. Biological effects of mammalian translationally controlled tumor protein (TCTP) on cell death, proliferation, and tumorigenesis. Biochemistry Research International, v. 2012, 2012.

NEVES, A. R. et al. Negative immunodiffusion test results obtained with sera of paracoccidioidomycosis patients may be related to low-avidity immunoglobulin $\mathrm{G} 2$ antibodies directed against carbohydrate epitopes. Clin Diagn Lab Immunol, v. 10, n. 5, p. 802-807, 2003.

NICOLA, A. M. et al. The stress responsive and morphologically regulated hsp90 gene from Paracoccidioides brasiliensis is essential to cell viability. BMC microbiology, v. 8, p. 158, 2008.

NICOLA, A. M.; ANDRADE, R. V.; SILVA-PEREIRA, I. Molecular chaperones in the Paracoccidioides brasiliensis transcriptome. Genetics and molecular research : GMR, v. 4, n. 2, p. 346-357, 2005.

NOBELPRIZE.ORG. Yoshinori Ohsumi - Banquet Speech.

NOMBELA, C.; GIL, C.; CHAFFIN, W. L. Non-conventional protein secretionin yeast. Trends in Microbiology, v. 14, n. 1, p. 15-21, 2006. 
NUCCI, M.; COLOMBO, A. L.; QUEIROZ-TELLES, F. Paracoccidiodomycosis. Current Fungal Infection Reports, v. 3, n. 1, p. 15-20, 2009.

OBENDORF, D. L.; PEEL, B. F.; MUNDAY, B. L. Mucor amphibiourum infection in platypus (Ornithorhyncus anaticus) from Tasmania. Journal of wildlife diseases, v. 29, n. 1983, p. 485-487, 1993.

PACE, C. .; M, S. Measuring the conformational stability of a protein. In: CREIGHTON, T. . (Ed.). . Protein Structure: A practical approach. [s.I.] Oxford University Press, 1997. p. 299-321.

PEREIRA, L. A. et al. Proteomic identification, nucleotide sequence, heterologous expression and immunological reactivity of the triosephosphate isomerase of Paracoccidioides brasiliensis. Microbes and Infection, v. 6, n. 10, p. 892-900, 2004.

PETERSEN, T. N. et al. SignalP 4.0: discriminating signal peptides from transmembrane regions. Nature Methods, v. 8, p. 785-786, 2011.

POON, S. et al. Clusterin is an ATP - Independent chaperone with very broad substrate specificity that stabilizes stressed proteins in a folding-competent state. Biochemistry, v. 39, n. 51, p. 15953-15960, 2000.

PRADO, M. et al. Mortality due to systemic mycoses as a primary cause of death or in association with AIDS in Brazil: A review from 1996 to 2006. Memorias do Instituto Oswaldo Cruz, v. 104, n. 3, p. 513-521, 2009.

QI, Y. et al. Proteome analysis and serological characterization of surface-exposed proteins of Rickettsia heilongjiangensis. PLoS ONE, v. 8, n. 7, 2013.

RINNERTHALER, M. et al. Mmi1, the yeast homologue of mammalian TCTP, associates with stress granules in heat-shocked Cells and modulates proteasome activity. PLoS ONE, v. 8, n. 10, 2013.

ROBERT, V. A.; CASADEVALL, A. Vertebrate Endothermy Restricts Most Fungi as Potential Pathogens. Journal of Infectious Diseases, v. 200, n. 10, p. 1623-1626, 2009.

SAMBROOK, J.; RUSSEL, D. W. The Inoue method for preparation and transformation of competent E. coli: "ultra-Competent" cells. In: Molecular Cloning: A laboratory manual. Third ed. [s.I.] CSHL Press, 2001a. p. 112-115.

SAMBROOK, J.; RUSSEL, D. W. The Hanahan method for preparation and transformation of competent E. coli: high-efficiency Transformation. In: Molecular Cloning: A laboratory manual. Third ed. [s.I.] CSHL Press, 2001b. p. 110-111.

SAMBROOK, J.; RUSSEL, D. W. Preparation of plasmid DNA by alkaline lysis with SDS: minipreparation. In: Molecular Cloning: A laboratory manual. Third ed. [s.I.] CSHL Press, 2001c. p. $32-35$.

SEO, E.-J.; EFFERTH, T. Interaction of antihistaminic drugs with human translationally controlled tumor protein (TCTP) as novel approach for differentiation therapy. Oncotarget, v. 7, n. 13, p. 1681816839, 2016.

SEO, J. S. et al. The intertidal copepod Tigriopus japonicus small heat shock protein 20 gene (Hsp20) enhances thermotolerance of transformed Escherichia coli. Biochemical and Biophysical Research Communications, v. 340, n. 3, p. 901-908, 2006. 
SIEVERS, F. et al. Fast, scalable generation of high-quality protein multiple sequence alignments using Clustal Omega. Molecular systems biology, v. 7, n. 1, p. 539, 2011.

SOTO, A. et al. Heterologous Expression of a Plant Small Heat-Shock Protein Enhances Escherichia coli Viability under Heat and Cold Stress. Plant Physiology, v. 120, n. 2, p. 521-528, 1999.

SURAGANI, M. et al. Human resistin, a proinflammatory cytokine, shows chaperone-like activity. Proceedings of the National Academy of Sciences, v. 110, n. 51, p. 20467-20472, 2013.

TEIXEIRA, M. M. et al. Phylogenetic analysis reveals a high level of speciation in the Paracoccidioides genus. Molecular Phylogenetics and Evolution, v. 52, n. 2, p. 273-283, 2009.

THAW, P. et al. Structure of TCTP reveals unexpected relationship with guanine nucleotide-free chaperones. Nature structural biology, v. 8, n. 8, p. 701-704, 2001.

TIWARI, S. et al. Role of Heat-Shock Proteins in Cellular Function and in the Biology of Fungi. Biotechnology Research International, v. 2015, p. 1-11, 2015.

UNTEREINER, W. A. et al. The Ajellomycetaceae, a new family of vertebrate-associated Onygenales. Mycologia, v. 96, n. 4, p. 812-821, 2004.

VERGHESE, J. et al. Biology of the heat shock response and protein chaperones: budding yeast (Saccharomyces cerevisiae) as a model system. Microbiology and molecular biology reviews : MMBR, v. 76, n. 2, p. 115-58, 2012.

VIDAL, M. S. M. et al. Serological diagnosis of paracoccidioidomycosis: high rate of inter-laboratorial variability among medical mycology reference centers. PLoS Neglected Tropical Diseases, v. 8, n. 9, p. 4-9, 2014.

WEBER, S. S. et al. Analysis of the Secretomes of Paracoccidioides Mycelia and Yeast Cells. PLoS ONE, v. 7, n. 12, 2012.

YANG, X.; YU, X. An introduction to epitope prediction methods and software. Reviews in medical virology, v. 19, p. 77-96, 2009.

ZHANG, C. et al. Identification of 19 polymorphic major outer membrane protein genes and their immunogenic peptides in Ehrlichia ewingii for use in a serodiagnostic assay. Clinical and Vaccine Immunology, v. 15, n. 3, p. 402-411, 2008. 